

\section{DISCLAIMER}

This report was prepared as an account of work sponsored by an agency of the United States Government. Neither the United States Government nor any agency Thereof, nor any of their employees, makes any warranty, express or implied, or assumes any legal liability or responsibility for the accuracy, completeness, or usefulness of any information, apparatus, product, or process disclosed, or represents that its use would not infringe privately owned rights. Reference herein to any specific commercial product, process, or service by trade name, trademark, manufacturer, or otherwise does not necessarily constitute or imply its endorsement, recommendation, or favoring by the United States Government or any agency thereof. The views and opinions of authors expressed herein do not necessarily state or reflect those of the United States Government or any agency thereof. 


\section{DISCLAIMER}

Portions of this document may be illegible in electronic image products. Images are produced from the best available original document. 


\section{LEGAL NOTICE}

This report was prepared as an account of Government sponsored work. Neither the United States, nor the Commission, nor any person acting on behalf of the Commission:

A. Makes any warranty or representation, expressed or implied, with respect to the accuracy, completeness, or usefulness of the information contained in this report, or that the use of any information, apparatus, method, or process disclosed in this report may not infringe privately owned rights; or

B. Assumes any liabilities with respect to the use of, or for damages resulting from the use of any information, apparatus, method, or process disclosed in this report.

As used in the above, "person acting on behalf of the Commission" includes any employee or contractor of the Commission, or employee of such contractor, to the extent that such employee or contractor of the Commission, or employee of such contractor prepares, disseminates, or provides access to, any information pursuant to his employment or contract with the Commission, or his employment with such contractor.

Printed in the United States of America

Available from

Clearinghouse for Federal Scientific and Technical Information

National Bureau of Standards, U. S. Department of Commerce

Springfield, Virginia 22151

Price: Printed Copy $\$ 3.00 ;$ Microfiche $\$ 0.65$ 
TID-4500

\title{
A COMPUTER PROGRAM FOR INDEXING CRYSTALS FROM THEIR X-RAY POWDER PATTERNS
}

\author{
Clinton R. Heiple
}

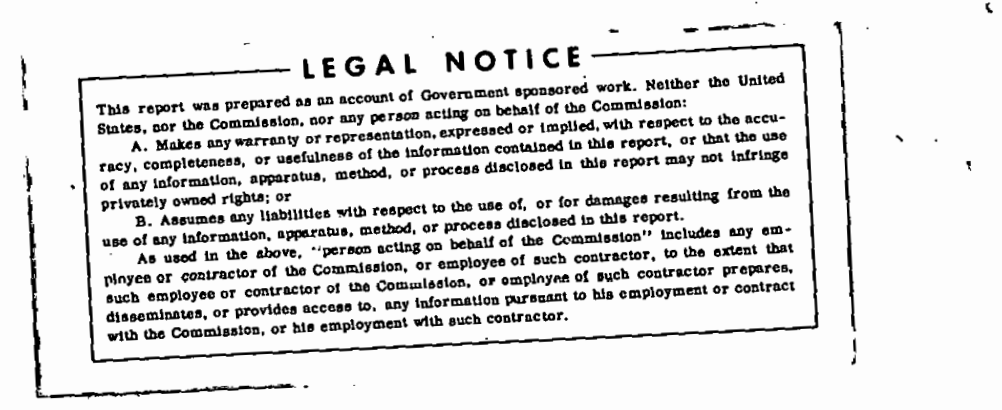

THE DOW CHEMILAL CUMPANY ROCKY FLATS DIVISION

P. O. BOX 888

GOLDEN, COLORADO 80401

U. S. ATOMIC ENERGY COMMISSION CONTRACT AT $(29-1)-1106$ 


\section{THIS PAGE \\ WAS INTENTIONALLY \\ LEFT BLANK}




\section{CONTENTS}

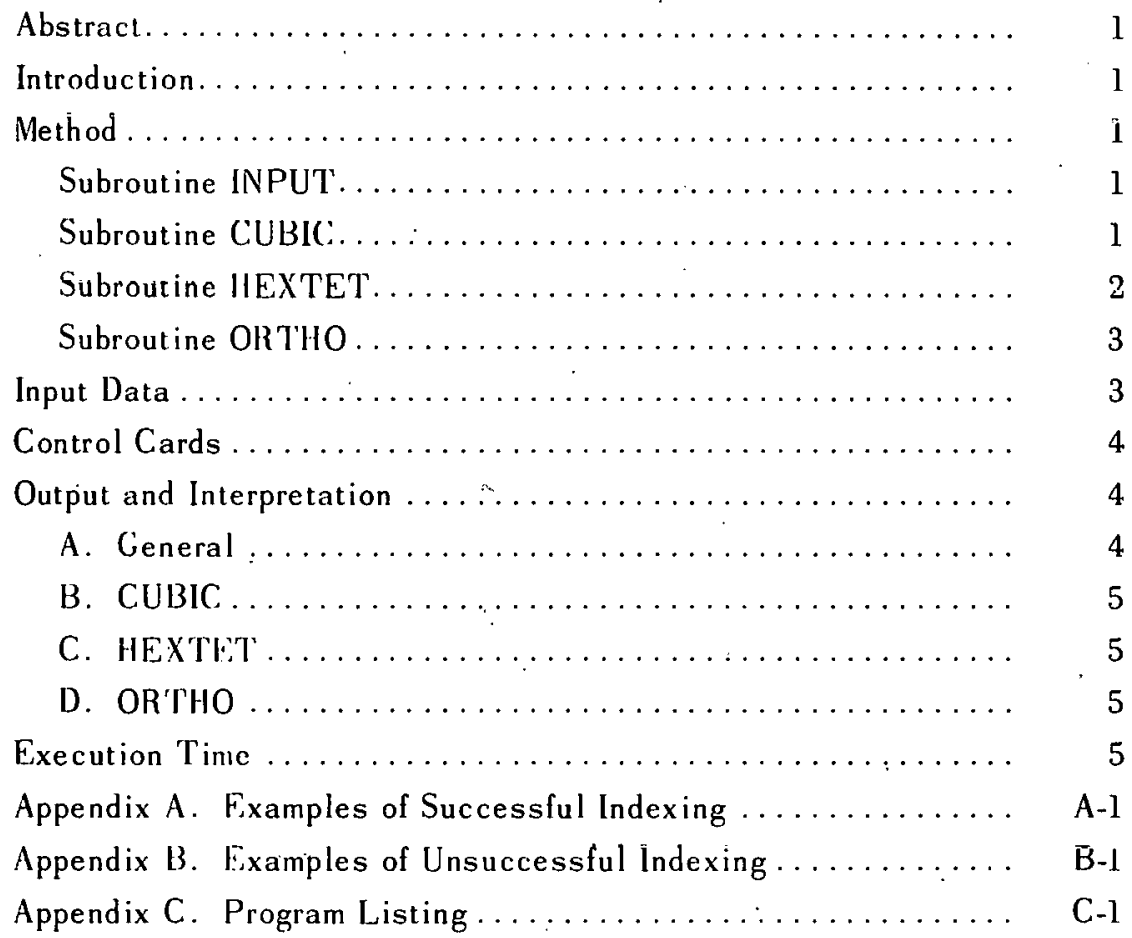




\section{A CKNOWLEDGMENTS}

Assistance in solving some of the problems associated with converting INDEX from the IBM 7094 to the IBM 360/40 was obtained from Corning Glass Works. They recently successfully converted INDFXX and their assistance is gratefully acknowledged. M. Brusberg in the Data Processing Group at Rocky Flats was also very helpful in solving some of the conversion problems. 


\title{
A COMPUTER PROGRAM FOR INDEXING CRYSTALS FROM THEIR $X$-RAY POWDER PATTERNS
}

\author{
Clinton R. Heiple
}

\begin{abstract}
INDEX is a computer program written in Fortran IV-G which indexes materials on the basis of their $X$-ray powder patterns. The program can be run on the IBM 360,40 . Crystals belonging to the cubic, hexagonal, tetragonal, and orthorhombic classes can be indexed by supplying the $2 \theta$ reflections, where $\theta$ is the Bragg angle.
\end{abstract}

\section{INTRODUCTION}

The original program for crystal indexing was obtained from Battelle-Northwest Laboratories and was written by J. B. Goebel and A. S. Wilson for. the IBM 7090 computer.

Unfortunately, the program as-received made use of a Share subroutine unavailable to us as well as a FAP assembly language subroutine unusable with the IBM 360 , and was in several other ways incompatible with the 360 .

INDEX consists of a main program and four subroutines. Three of the subroutines index the material on the bas is of cubic, hexagonal, tetragonal, and orthorhombic symmetry, and the fourth performs cerlaii preliminary calculatione with the input data.

The user must supply the measured $2 \theta$ values (where $\theta$ is the Bragg angle in degrees). The $\mathrm{X}$-ray wavelength used must also be supplied unless $C u$ radiation was employed. The user may also supply other optional information, including the density and formula weight of the crystal and a selection of which symmetry classes, if any, will not be tried for any set of data. The input is described fully in Section III. It should be noted that an attempt to correctly index crystals with poor or mediocre data is hopeless.

The problem hernmes more severe for lower symmetry crystals. Errors of less than $1 / 2$ of a degree in $2 \theta$ can produce erroneous indexing even for hexagonal criystals. INDEX will produce an indexing for any set of data, but while the results may appear precise upon preliminary inspection, they may be of no significance whatever. Examples of incorrect indexings produced by inadequate data are given in Appendix B. In addition, if spurious reflections from a second phase or other source are included in the input data the chances for a correct indexing are very small.

\section{METHOD}

A brief description of the method used in the four subroutines which make up the program is given below. For a somewhat more complete description, the user is referred to the original description of INDEX by its authors. ${ }^{1}$ In the following descriptions, $h, k$, and $l$ are the Miller indices of the reflecting planes; $a_{o}, b_{o}$, and $c_{o}$ are the lattice parameters; and $\lambda$ is the $X$-ray wavelength.

\section{Subroutine INPUT}

INPUT reads the input data, including the angles that are in the form of $2 \theta$. Up to 150 values of $2 \theta$ may be given. The $2 \theta$ values are converted to $\sin ^{2} \theta$. The $\sin ^{2} \theta$ values for reflections where $K \alpha_{1}$ and $K a_{2}$ lines are not resolved are multiplied by the ratio $\lambda_{K a_{1}} / \lambda_{A V G}$ to normalize the unresolved reflections to the $K a_{1}$ reflections used when $K a_{1}$ and $K a_{2}$ are resolved. The quantity $\lambda_{\mathrm{K} a_{1}}$ is the wavelength in Angstroms of the $K a_{1}$ line used and $\lambda_{A V G}$ is the unresolved wavelength.

\section{Subruatine CUBIC}

The reflections from a cubic crystal of lattice constant $a_{0}$ must satisfy the Bragg relation $\sin ^{2} \theta=$ $\lambda^{2} / 4 \mathbf{a}^{2}\left(h^{2}+k^{2}+l^{2}\right)$. The subroutine therefore seeks solutions to the set of $\mathrm{N}$ equations

\footnotetext{
${ }^{1}$ J. E. Goebel and A. S. Wilson, "Index, A Computêf Program for Indexing X-ray Diffraction Powder Patterns," BNWL-22, 1965.
} 


$$
\sin ^{2} \theta_{i}=X n_{i}
$$

where

$$
\begin{aligned}
& \mathrm{X}=\frac{\lambda^{2}}{4 \mathrm{a}_{0}} \\
& \mathrm{n}_{\mathrm{i}}=\left(\mathrm{h}_{\mathrm{i}}{ }^{2}+\mathrm{k}_{\mathrm{i}}{ }^{2}+l_{\mathrm{i}}{ }^{2}\right) \\
& \mathrm{i}=1,2, \ldots \mathrm{N}
\end{aligned}
$$

and $N$ is the number of $2 \theta$ reflections given.

The program calculates those integers which are not possible sums of $\mathrm{h}_{\mathrm{o}}{ }^{2}, \mathrm{k}_{\mathrm{o}}{ }^{2}$, and $l_{\mathrm{o}}{ }^{2}$ (seven, for example). The program then generates a one dimensional array $F$ with elements $f_{1}, f_{2}, \ldots f_{9 g 9}$ such that

$\mathrm{f}_{\mathrm{i}}=0$ if $\mathrm{j}$ is one of the forbidden integers calculated previously

$f_{j}=j$ otherwise

Because of the known inaccuracies of low angle reflections, the entire indexing is derived from the last half of the set of angles. Setting $k$ equal to the largest integer not greater than $N / 2$, i.e., $k=$ $[N / 2]$, a trial value of $x$ is found by setting $x=$ $\sin ^{2} \theta_{k} / f_{k}$. (If $f_{k}=0$, the first nonzero $f_{j}$ for $j>k$ is used.) A test is then made to see if there exists a set of integers $n_{i}$ contained in the array $F$ such that

$$
\left|\frac{\sin ^{2} \theta_{i}}{x}-n_{i}\right|<E \text { for } \mathrm{i}=k, k+1, \ldots, N \text {, }
$$

where $E=0.2$. If no such set of integers exists, a new value of $x, x=\sin ^{2} \theta_{k} / f_{k+1}$, is tried and the above procedure repeated. If no solution exists for all possible values of $x$ (i.e., for $[N / 2] \leq k \leq N$ in the trial values of $x$ ), then $E$ is doubled and the procedure repeated. When a solution is found, $\mathrm{E}$ is divided by two and the above process repeated. Subsequently $E$ is varied in a somewhat obscure manner until a final solution is reached. The final solution is the one such that a reduction of 0.01 in $E$ will result in no solution. A least squares analys is of the $n_{i}$ found in the final solution versus the measured $\sin ^{2} \theta_{i}$ is used to calculate the best value of $x$, called $\hat{a}$. The $n_{i}$ for the first half of the reflections are calculated using $\hat{a}$ and the experimental $\sin ^{2} \theta_{i}$. The lattice constant $a_{0}=\left(\lambda^{2} / 4 \hat{a}\right)^{1 / 2}$, and "calculated $\sin ^{2} \theta$ " $=\hat{a} n_{i}$, for $i=1, \ldots, N$ are calculated. The quantity $\mathrm{E}$ is called the error in the output. The input parameter ETEST is not used in any way in CUBIC.

\section{Subroutine HEXTET}

Subroutine HEXTET generates indexings on a hexagonal and then on a tetragonal basis. Any set of reflections can in general be indexed as hexagonal and as tetragonal, so the user must judge the validity of the various indexings on the basis of the output from HEXTET.

IIEXTET seeks solutions to the set of $\mathrm{N}$ equations (where $\mathrm{N}$ is the number of $2 \theta$ reflections given):

$$
\begin{aligned}
& \sin ^{2} \theta_{i}=X s_{j}+Y r_{i} \\
& i=1,2, \ldots N
\end{aligned}
$$

where for the hexagonal system

$$
\begin{aligned}
& X=\frac{\lambda^{2}}{3 a_{0}{ }^{2}} \\
& Y=\frac{\lambda^{2}}{4 \sigma_{n}^{2}} \\
& s_{i}=\left(h_{i}^{2}+h_{i} k_{i}+k_{i}{ }^{2}\right) \\
& r_{i}=l_{i}^{2}
\end{aligned}
$$

and for the tetragonal system

$$
\begin{aligned}
& X=\frac{\lambda^{2}}{\mathrm{a}_{0}{ }^{2}} \\
& Y=\frac{\lambda^{2}}{4 \mathrm{c}_{\mathrm{o}}{ }^{2}} \\
& \mathrm{~s}_{\mathrm{i}}=\left(\mathrm{h}_{\mathrm{i}}{ }^{2}+\mathrm{k}_{\mathrm{i}}{ }^{2}\right) \\
& \mathrm{r}_{\mathrm{i}}=l_{\mathrm{i}}{ }^{2}
\end{aligned}
$$

In order to solve the set of equations (2), the subroutine generates all possible distinct values of $s_{j}$ and $r_{j}$ for $s_{j}<1000$ and $r_{j}<32^{2}$ in order of ascending values. In setting up the array $S$ in the original 
program, IIEXXTF'l called a Share subroutine, WDSORT, to arrange $s_{j}$ in order of ascending values. This is an clegant sorting routine. but since it has been unavailable to us its function has been replaced with a simple bubble sorting procedure. Equations (2) are solved by picking $s_{1}, s_{2}, r_{1}$, and $r_{2}$ from the arrays $S$ and $R$. The first two equations are then solved for $X$ and $Y$. These values of $X$ and $Y$ are then used to calculate $\sin ^{2} \theta_{3}$. If / calculated $\sin ^{2} \theta_{3}$ - observed $\sin ^{2} \theta_{3} \mid \leq F . s_{3} s_{2} \cdot r_{3} r_{2}$, and this $s_{3}$ and $r_{3}$ give the best agreement between calculated and obscrved $\sin ^{2} \theta_{3}$, then th is $s_{3}$ and $r_{3}$ arc accepted. 'The quantity $F$ is equal to the smallest difference betwcen successive $\sin ^{2} \theta$ values. The fourlh reflection is treated similarly. Now a new $I$ and $Y^{\prime}$ are determined by a least squares technique and are used to try to index the rest of the reflections. If this is impossible, new starting $s_{i}$ and $r_{i}$ values are used and the procedure repeated. If no solution is found using any of the first five elements of the $S$ and $R$ arrays, an attempt is made with wice the original $r$. If no successful indexing is achieved the program takes the next case. If an indexing is successful, li: is halved and another indexing attempled. When $\mathrm{F}$ is reduced to the smallest value for which an indexing can be achieved. five solutions at most. for this min imum l. will be printed. In finding the minimum

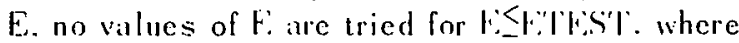
FTFS' is an input parameter described in Section III. Solutions for $\because:$ : larger by multiples of two than the minimum are also calculated and printed in order of decreasing $\mathrm{E}$.

\section{Subroutine OR'Illo}

Subroutine Oli'lllo generates indeximgs on all urlhurhombic basis. Any set of reflections can be indexed as orthorhombic, so the user must judge the validity of the indexings on the basis of the output from ORTHO.

ORTIIO seeks solutions to the set of $N$ equations (where $N$ is the number of 20 reflections given):

$$
\begin{aligned}
& \sin ^{2} \theta_{\mathrm{i}}=X \mathrm{X}_{\mathrm{i}}{ }^{2}+\mathrm{Y}_{\mathrm{i}}{ }^{2}+\mathrm{Z} \mathrm{L}_{\mathrm{i}}^{2} \\
& \mathrm{i}=\mathrm{l}, 2, \ldots \mathrm{N}
\end{aligned}
$$

where

$$
X=\frac{\lambda^{2}}{4 a_{0}^{2}}
$$

$$
\begin{aligned}
& y=\frac{\lambda^{2}}{1 \cdot b_{0}} \\
& y=\frac{\lambda^{2}}{4 c_{0}{ }^{2}}
\end{aligned}
$$

The first three of equations (4) are snlved for $X, Y$, and 7 by using tentative values of $h_{i}{ }^{2}, k_{i}{ }^{2}$. and $l_{i}{ }^{2}$ for $i=-1,2$, and 3 . 'The Miller indices are limited to the values 0,1 . and 2 for finding trial values of $X, Y$. and $Z$. With these trial values of $X, Y$, and $\%$ an attempt is made to index the fourth reflection. The process is the same as that described for Illxilit'. "The parameters lis and ETEST are found and used in the sane way. If no successful indexing is found wilhin twice the original $l \mathrm{l}$ using the 1254 combinations of the permitted trial Viller indices, the program procoeds to the next case. The combinations of Miller indices were obtained from a FAP subroutine in the original program. They are now read in INPITT and stored in COMMION. The program prints out at least one solution for the minimum F, found and solutions for F's larger by multiples of two than the minimum in order of decreasing $\mathrm{E}$.

\section{INITII IITI}

The card input for each set of data is as follows:

Card I

Columns 1-80 NAME NAME is a title. It will be printed at the top of each page.

\section{(iarl 2}

Columns t-5 :C.UT The number of unresolved reflections in the datia. All subscquent reflections are treated as $\mathrm{K} \alpha_{1}$ lines. Format 15

6-1.5 II.AMIDA The unresolved wavelength used, in angstroms. If $\mathrm{CuK}_{a}$ is used, XLAAlil)A may he left blank. Format $l=10.5$ 
16-25 YLAMDA The $K a_{i}$ wavelength used. If $\mathrm{CuK}_{a}$ is used, YLAMDA may be left blank.

Format F 10.5

26-35 ETEST The user's estimate of the maximum difference between actual and observed $\sin ^{2} \theta$. HEXTET and ORTHO will not search for solutions which E<ETEST. (See Section II.) If ETEST is left blank, a value of 0.0005 is assumed by the program. Format F 10.5

36-45 I'EE'I'BLK 'I'he tetragnal indexing delete parameter. If it is left blank, tetragonal indexing will be tried. If TETBLK is a positive number, no tetragonal indexing will be tried. Format $F 10.5$

46-55 FORMWT The empirical gram formula weight of the sample. If it is left blank, "number" will be zero in the output. Format F 10.5

56-65 DENSTY The observed density in grams $/ \mathrm{cm}^{3}$. If it is left blank, "number" will be zero in the output. Format F 10.5

NOCUBE The cubic indexing delete parameter. If NOCIJBE: is nonzero (or not left blank), no cubic indexing will be tried. Format Il

NOHEX The hexagonal indexing delete parameter. If NOHEX is nonzero (or not left blank), no hexagonal indexing will be tried. Format II
The orthorhombic indexing delete parameter. If NONO is nonzero (or not left blank), no orthorhombic indexing will be tried. Format Il

Card 3

$\begin{array}{rr}\text { Columns } & 1-10 \\ 11-20\end{array}$

The $2 \theta$ angles in degrees, seven angles per card, in order of increasing $2 \theta$. Limit, 150 angles.

Format $7 \mathrm{~F} 10.2$

\section{CONTIROL CARDS}

No control cards need to be supplied with the data since they are provided by the computer operators. A production job roquest form, will puvedure number

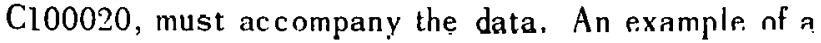
completed job form follows. (See Page 5.)

\section{UU'IPUT $\Lambda$ ND INTERPRETATION}

\section{A. General}

The quantity "error" printed out from all the subroutines is E, described under METHOD. "Number" is the number of formula units per unit cell. It is calculated from the empirical formula weight and density (when they are supplied as input data) and the calculated unit cell parametcrs. The standard deviations of various calculated quantities are also included. They are calculated in the standard way and are self-explanatory. The tabulated values of "calculated $\sin ^{2} \theta$ " are calculated using the assigned Miller indices for each reflection and the calculated lattice parameters. 


\section{B. CUBIC}

The tabulated quantities "calculated N" produced are the sum of the squares of the Miller indices for the reflection.

CUBIC will index any set of reflections on a cubic basis, so the user must determine the validity of the indexing. Non-cubic crystals usually result in "error" greater than 0.25 , while cubic crystals yield "error" less than about 0.2 . Since the indexing is based on the second half of the data, forbidden integers (those which cannot be the sum of the squares of Miller indices, like 7 or 15) may be assigned to some reflections in the first half of the data. This indicates an invalid indexing. Furthermore, valid indexings usually have differences between observed and calculated $\sin ^{2} \theta$ less than about 0.0005 , while differences for invalid indexings may be larger. Unreasnnahly large lattice parameters or numbers of formula units per unit cell may also indicate an invalid indexing.

Extraneous reflections from a second phase will normally produce an invalid indexing if located in the second half of the data. If they are only in the first half of the data they will not affect the indexing, but they may be assigned forbidden integers or have unusually large differences between calculated and observed $\sin ^{2} \theta$.

\section{HEXTET}

A correct indexing will have a combination of a low number of formula units per unit cell (and it should be close to an integer), a low "error," good agreement between calculated and measured $\sin ^{2} \theta$ values, and relatively small lattice constants. With regard to the agreement between calculated and measured $\sin ^{2} \theta$, the user would be advised to run a known sample on his equipment and index it with this program. He will then be able to find the expected standard deviation in $\sin ^{2} \theta$ for his equipment for a valid indexing.

\section{ORTHO}

The comments on interpretation of the results of ORTHO are the same as for HEXTET.

\section{EXECUTION TIME}

The time required for execution is a somewhat erratic function of the quality of the input data and the number of reflections used. ORTHO normally is the slowest subroutine, and can take as long as $25 \mathrm{~min}$ utes on a single case. The user is therefore strongly advised not to execute ORTHO for crystals known not to be of orthorhombic symmetry. An average case where all the symmetry classes are attempted takes on the order of 5-15 minutes. Execution time is given for each of the examples in Appendix A and $B$ as an aid in estimating execution times.

The user is requested not to run so many cases at once that the execution time will substantially exceed 30 minutes. In addition, the program checks execution time while in ORTHO and stops if total execution time exceeds 33 minutes.

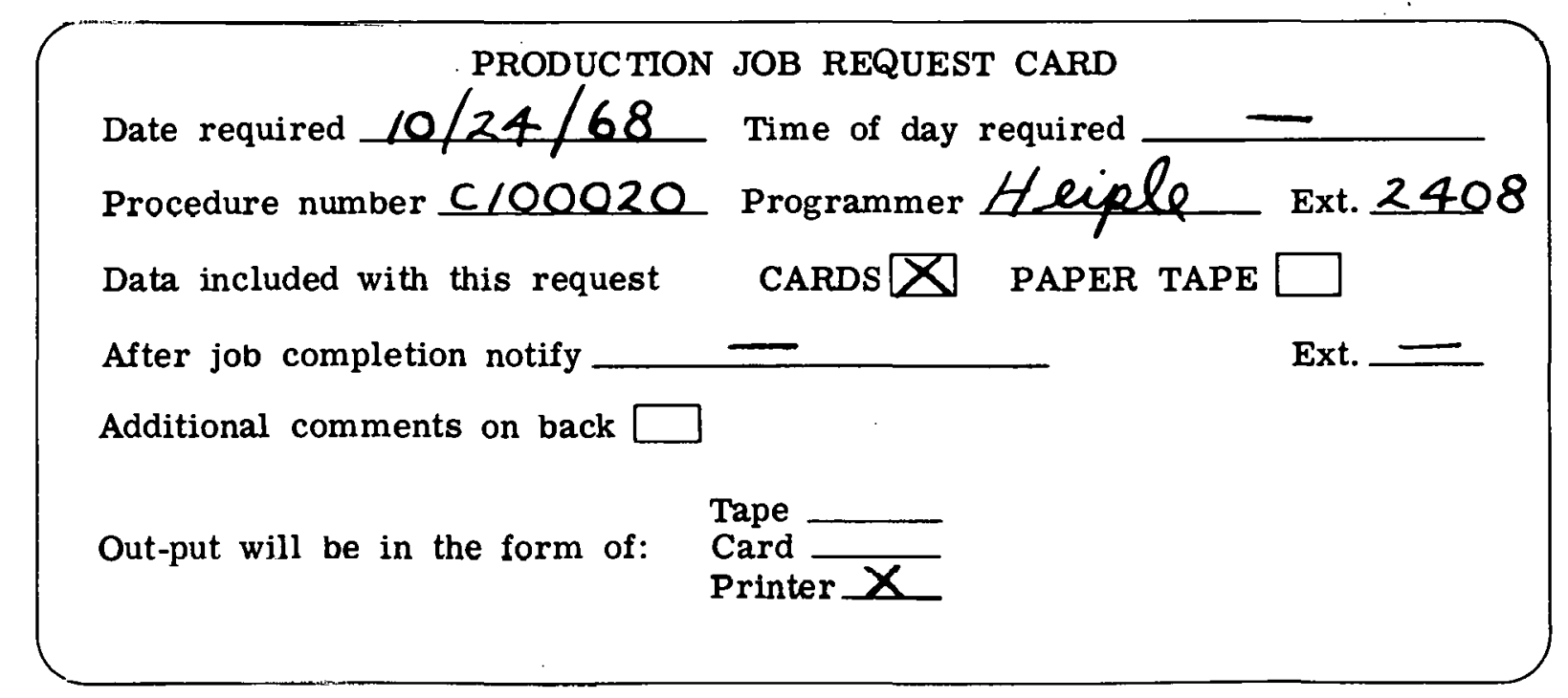


THIS PAGE

WAS INTENTIONALLY

LEFT BLANK 


\section{APPENDIX A. EXAMPLES OF SUCCESSFUL INDEXING}

Appendix A in cludes the control cards and data cards used to index delta-plutonium (f.c.c.), hafnium (hexagonal), delta prime-plutonium (tetragonal), ice III (orthorhombic) and magnesium silicate (orthorhombic), along with the computer output for each material.

\section{EXAMPLE 1. Delta Plutonium (Cubic)}

The correct lattice parameter is 4.616 angstroms. Execution time was 91.1 seconds.

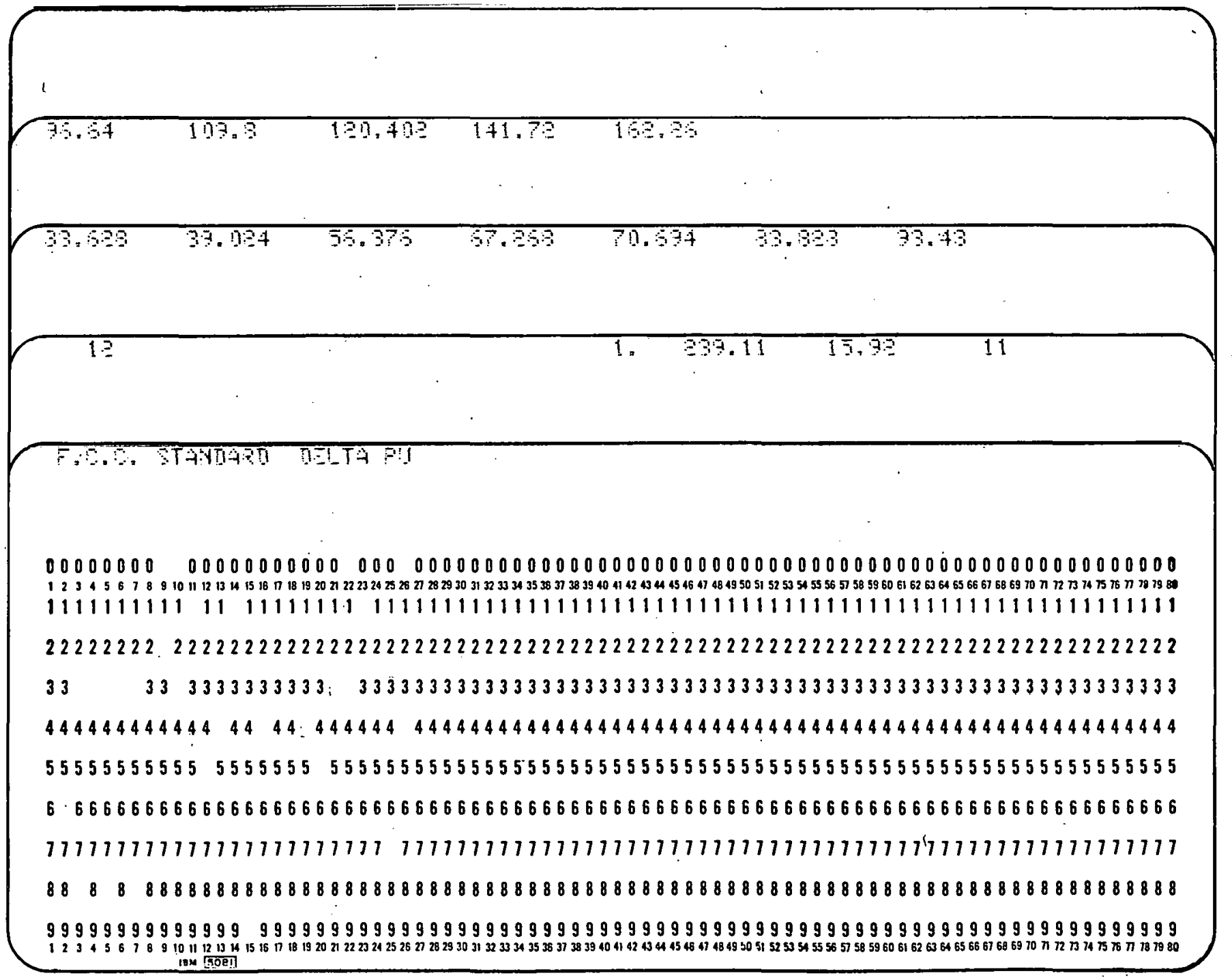


ERROR IS

0.0031

THE NUMBER OF FORMULA UNITS PER UNIT CELL IS THE NUMBER DF FORMULA UNITS PER UNIT CELL IS
THE CRYSTAL HAS BEEN INDEXED IN THE CUBIC SYSTEM WITH A LATTICE CONSTANT OF 4.6160 ANGSTROMS. AN ESTIMATE DF THE STANDARD DEVIATION OF THE LATTICE CONSTANT IS 0.000000

THO THETA
33.63
39.02
56.38
67.27
70.69
83.83
93.43
96.64
109.80
120.40
141.72
162.26

CALCULATED N

3. 00000

4.00000
8.00000

11.00000

12. 00000

16.00000

19.00000

20.00000

24.00000

27. 00000

32.00000

35.00000
OBSERVEO

SINE SQUARED THETA

0.08353

0.11137

0.22276

0.30628

0.33413

0.44550

0.52903

0.66825

0.7517

0.89100
CAL CULAT:DO

SINE SQUARED THETA

0.08353

0.11138

0.22275

0.30629

0.33413

0.44551

0.52904

C. 55688

0.66826

0.75179

0.89101

0.97455
DIFFERENCE

0.00000

$-0.00000$

0.00000

$-0.00001$

0.00000

$-0.00001$

$-0.00001$

$-0.00000$

$-0.00001$

$-0.00002$

$-0.00001$

0.00005

ENTERING HEXTET. EXECUTION TIME 91.10 SEC. 
EXAMPLE 2. Hafnium (Hexagonal)

The correct lattice parameters are $a_{0}=3.1967$ angstroms and $C_{0}=5.0578$ angstroms.

Execution time was 98 seconds.

$13.11 \quad 141.19$

$\begin{array}{lllllll}77.47 & 191.71 & 179.93 & 193.91 & 111.19 & 130.07 & 125.4\end{array}$

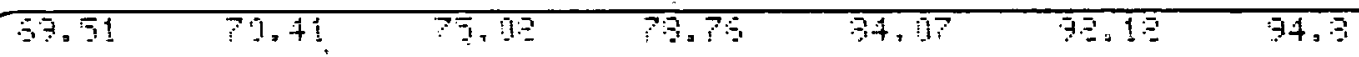

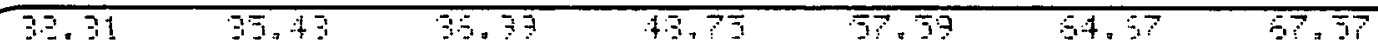

1.

179.5

13,248

11

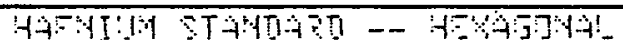

0000000000000000000000000000000000000000000000000000000000000000000000000000

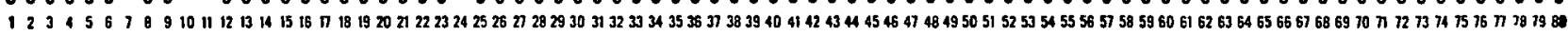
111111111111111111111111111111111111111111111111111111111111111111111111111

2222222222222222222222222222222222222222222222222222222222222222222222222222222 $3333333333 \quad 333333333333333333333333333333333333333333333333333333333333333333333$

$444444 \quad 44444 \quad 44444444444444444444444444444444444444444444444444444444444444444$ 5555555555555555555555555555555555555555555555555555555555555555555555555555 666666666666666666666666666666666666666666666666666666666666666666666666666666

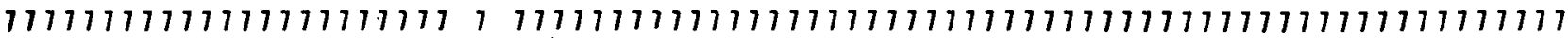

888888888888888888888888888888888888888888888888888888888888888888888888888888

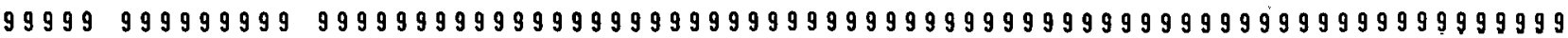

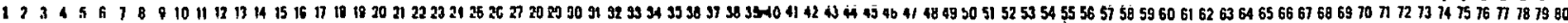
inx [500] 
THE FOLLOWING INDEXING IS ON THE BASIS OF THE TEXAGONAL SYSTEM WITH THE ERROR LESS THAN O.0OT23I

THE UNRESOLVED WAVELENGTH USED WAS 1.54180 ANE THE K-ALPHA-ONE WAVELENGTH USED HAS 1.54051

THE DENSITY IS 13.248, THE FORMULA WEIGHT IS 178.500 , AND THE NUMBER IS 17.430.

THE FIRST 0 LINES ARE UNRESOL VED. THE REST APE K-ALPHA-1 LINES.

AN ESTIMATE OF THE STANDARD DEVIATION OF SINE SQUARED THETA IS

AN EST IMATE DF THE STANDARD DEVIATION OF THETA IS 0.0989

0.0015

AN ESTIMATE DF THE STANDARD DEVIATION OF AZERO IS

AN ESTIMATE DF THE STANDARD DEVIATION OF CIERO IS 0.1424

AHAT IS 0.004831 BHAT IS 0.078039

THE LATTICE CONSTANT AZERO IS 12.79683 ANGSTFOMS.

THE LATTICE CONSTANT C.ZERO IS 2.75727 ANGSTFOMS.

THO THETA

$H H+K K+H K$

LL

OBSERVEO

CAL CULATED

SINE SOUARED THETA

DIFFERENCE

$$
\begin{aligned}
& 32.310 \\
& 35.430 \\
& 36.590 \\
& 49.750 \\
& 57.590 \\
& 64.670 \\
& 67.570 \\
& 69.510 \\
& 70.410 \\
& 75.520 \\
& 78.760 \\
& 84.070 \\
& 92.120 \\
& 94.800 \\
& 97.470 \\
& 101.510 \\
& 105.580 \\
& 108.310 \\
& 111.1180 \\
& 120.570 \\
& 125.400 \\
& 132.110
\end{aligned}
$$

16
3
21
19
48
43
64
67
4
12
67
29
91
112
117
109
67
121
76
139
147
108
39

$$
\begin{aligned}
& 0.07742 \\
& 0.09259 \\
& 0.10063 \\
& 0.17033 \\
& 0.23201 \\
& 0.2860 .8 \\
& 0.30922 \\
& 0.32498 \\
& 0.33236 \\
& 0.37076 \\
& 0.40254 \\
& 0.44834 \\
& 0.51850 \\
& 0.54184 \\
& 0.56500 \\
& 0.60319 \\
& 0.63429 \\
& 0.65708 \\
& 0.68065 \\
& 0.75053 \\
& 0.78964 \\
& 0.83528 \\
& 0.88929
\end{aligned}
$$

$$
\begin{aligned}
& 0.07729 \\
& 0.09253 \\
& 0.10144 \\
& 0.16982 \\
& 0.23187 \\
& 0.28576 \\
& 0.30916 \\
& 0.32365 \\
& 0.33148 \\
& 0.37012 \\
& 0.40169 \\
& 0.44741 \\
& 0.51763 \\
& 0.54103 \\
& 0.56518 \\
& 0.60458 \\
& 0.63581 \\
& 0.66254 \\
& 0.67928 \\
& 0.74950 \\
& 0.78814 \\
& 0.83386 \\
& 0.89074
\end{aligned}
$$

$$
\begin{array}{r}
0.00013 \\
0.00006 \\
-0.00081 \\
0.00051 \\
0.00014 \\
0.00033 \\
0.00006 \\
0.00133 \\
0.00088 \\
0.00064 \\
0.00085 \\
0.00093 \\
0.00087 \\
0.00081 \\
-0.00018 \\
-0.00139 \\
-0.00152 \\
-0.00547 \\
0.00137 \\
0.00103 \\
0.00150 \\
0.00142 \\
-0.00146
\end{array}
$$$$
\begin{array}{r}
0.00142 \\
-0.00146
\end{array}
$$ 
THE FOLLDWING INCFXING IS TN THE BASIS OF THE HEXAGONAL SYSTEM WITH THE ERROR. LESS THAN O. OOBGIS

THE IINRESOLVFD WAVELFNGTH USFD WAS 1.54180 AND THE K-ALPHA-ONE WAVELENGTH USED WAS 1.54051

THE DENSITY IS 13.24\%, THE FORMULA WEIGHT IS 178.50\%. ANO THE NUMBER IS 2.001 .

THE FIRST $O$ LINES ARE UNRESOLVED: THE REST ARE K-ALPHA-1 LINES.

AN ESTIMATF DF THE STANDARD DFVIATION OF SINE SQUARED THETA IS 0.0002

AN ESTIMATE OF THE SIAVRAPD DEVIATION OF THETA IS.

AN FSTIMATE DF THE STANDARI DFVIATION OF AZERT IS 0.2153

AN FSTIMATE TF THF STANDARD DFVIATION OF C.ZFRO IS 0.3261

AHAT IS 0.077393 RHAT IS 0.023193

THF LATTICE CONSTANT ATERO IS 3.19708 ANGSTROMS.

THE LATTICE CONSTANT CZERO IS 5.05776 ANGSTROMS.

I TWD THFTA HH+KK+HK LL SINE SQUARED THETA SINE SQUARFO THFTA

SINE SQUARFO THFTA DIFFERFNCF

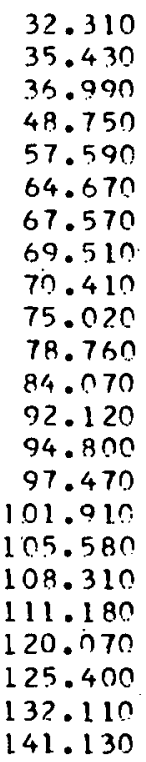

0.07742
0.09259
0.10063
0.17333
0.23201
0.28608
0.30927
0.32498
0.33236
0.37076
0.40254
0.44834
0.51850
0.54184
0.56500
0.60319
0.63429
0.65708
0.68065
0.75053
0.78964
0.83528
0.88929

0.07739

0.09277

0.10059

0.17016

0.23218

0.28613

0.30957

0.32495

0.33276

0.37108

0.40234

0.44848

0.51831

0.54175

0.56494

0.60326

0.63452

$0.657 ? 1$

0.68066

0.75048

0.78931

0.83494

0.00002

$-0.00018$

0.00004

0.00016

$-0.00017$

$-0.00004$

$-0.00035$

c. 00003

$-0.00041$

$-0.00033$

0.00020

$-0.00013$

0.00019

0.00009

0.00006

$-0.00008$

$-0.00023$

$-0.00013$

$-0.00001$

0.00004

0.00033

0.00034

$23 \cdot 141.130$

4

$-0.00011$ 
THE FOLLOWING INDEXING IS ON THE BASIS OF THE HEXAGONAL SYSTEM HITH THE ERRGR LESS THAN O. OOI8OR

THE UNRESILVED WAVFLENGTH USEO WAS 1.54180 AND THE K-ALPHA-TNE WAVFLENGTH USED WAS 1.54051 THE DENSITY IS 13.248 , THE FRPYILA WEIGHT IS 178.500 , AND THE NUMRER IS 2 .COI.

THE FIRST O LINES ARE UNRFSDLVEn. THE REST ARE K-ALPHA-1 LINES.

AV EST IMATE DF THE STANDART DEVIATION DF SINE SQUARED THETA IS 0.0002

AN. ESTIMATE DF THE STANIARD DEVIATION DF THETA IS. 0.0130

AN ESTIMATE TF THF STANDARD DEVIATION OF AZERD IS 0.0153

AN ESTIMATE TF THE STANDARI DEVIATINN OF CZFRO IS n.?26I

AHAT IS O.077373 'QHAT IS 0.023193

THE LATTICE CINSTANT AIFRC IS 3.19708 ANGSTROMS.

THE LATTICE CONSTANT CIERO IS 5.05776 ANGSTROMS.

I TWI THETA HH+KK+HK LL SINE SOUARED THETA SINE SQUARED THET

$\begin{array}{ll}1 & 32.310 \\ 2 & 35.430 \\ 3 & 36.990 \\ 4 & 48.750 \\ 5 & 57.590 \\ 6 & 64.670 \\ 7 & 67.570 \\ 8 & 69.510 \\ 9 & 70.410 \\ 10 & 75.020 \\ 11 & 78.760 \\ 12 & 84.070 \\ 13 & 92.120 \\ 14 & 94.800 \\ 15 & 97.470 \\ 16 & 101.910 \\ 17 & 105.580 \\ 18 & 108.310 \\ 10 & 111.180 \\ 20 & 120.070 \\ 21 & 125.400 \\ 22 & 132.110 \\ 23 & 141.130\end{array}$

0.07742
0.09259
0.10063
0.17033
0.23201
0.28608
0.30927
0.32498
0.33236
0.37076
0.40254
0.44834
0.51850
0.54184
0.56500
0.60319
0.63429
0.65708
0.58065
0.75053
0.78964
0.83528
0.38929

0.07739
0.09277
0.10059
0.17016
0.23218
0.28613
0.30957
0.32495
0.33276
0.37108
0.40234
0.44848
0.51831
0.54175
0.56494
0.60326
0.63452
0.65721
0.68066
0.75048
0.78931
0.83494
0.88939

DIFFER ENCE

0.00002

$-0.00018$

0.00004

0.00016

$-0.00017$

$-0.00004$

$-0.00035$

0.00003

$-0.00041$

$-0.00033$

0.00020

-0.00013 .

0.00019

0.00009

0.00006

$-0.00008$

$-0.00023$

$-0.00013$

$-0.00001$

$0.000 n 4$

0.00033

0.00034 
THE FOLLOWING INDFXING IS ON THF BASIS DF THE HEXAGONAL SYSTEM WITH THE ERROR LESS THAN O.OOOSO4

THE UNRESOLVED WAVFLENGTH USFD WAS 1.54180 AND THE K-ALPHA-ONE WAVELENGTH USED WAS L.54051

THE DENSITY IS 13.248 , THE FORMULA HEIGHT IS 178.500 . AND THE NUMBER IS 2.001.

THE FIRST 0 LIVES RRE UNRESOLVED. THE REST ARE K-ALPHA-1 LINES.

AN FSTIMATE DF THE STANIARD DEVIATIINN OF SINE SQUARED THETA IS 0.0002

AN ESTIMATE OF THF STANDARD DEVIATION DF THETA IS 0.0139

AN ESTIMATE DF THE STANDAR? DEVIATION DF AZFRO IS

AN ESTIMATE OF THE STANDARD DEVIATION DF CZERO IS 0.0261

AHAT IS 0.077373 PHAT IS 0.023193

THE LATTICE CONSTANT AZFRO IS 3.19708 ANGSTROMS.

THE LATTICE CONSTANT CZFRO IS 5.05776 ANGSTROMS.

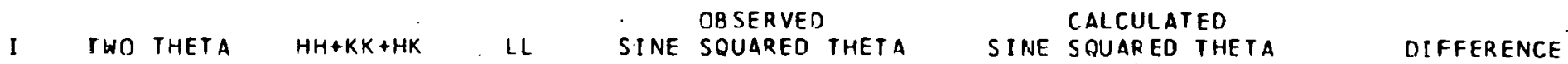

$\begin{array}{rrrrr}1 & 32.310 & 1 & 0 & 0.07742 \\ 2 & 35.430 & 0 & 4 & 0.09259 \\ 3 & 36.990 & 1 & 1 & 0.10063 \\ 4 & 48.750 & 1 & 4 & 0.17033 \\ 5 & 57.590 & 3 & 0 & 0.23201 \\ 6 & 64.670 & 1 & 9 & 0.28608 \\ 7 & 67.570 & 4 & 0 & 0.30922 \\ 8 & 69.510 & 3 & 4 & 0.32498 \\ 9 & 70.410 & 4 & 1 & 0.33236 \\ 10 & 75.020 & 0 & 16 & 0.37076 \\ 11 & 78.760 & 4 & 4 & 0.40254 \\ 12 & 84.070 & 1 & 16 & 0.44834 \\ 13 & 92.120 & 4 & 9 & 0.51850 \\ 14 & 94.800 & 7 & 0 & 0.54184 \\ 15 & 97.470 & 7 & 1 & 0.56500 \\ 16 & 101.910 & 3 & 16 & 0.60319 \\ 17 & 105.580 & 7 & 4 & 0.63429 \\ 18 & 109.310 & 1 & 25 & 0.65708 \\ 19 & 111.180 & 4 & 16 & 0.68065 \\ 20 & 120.070 & 7 & 9 & 0.75053 \\ 21 & 125.400 & 9 & 4 & 0.78964 \\ 22 & 132.110 & 0 & 36 & 0.83528 \\ 23 & 141.130 & 4 & 25 & 0.88929\end{array}$

$\begin{array}{lr}0.07739 & 0.00002 \\ 0.09277 & -0.00018 \\ 0.10059 & 0.00004 \\ 0.17016 & 0.00016 \\ 0.23218 & -0.00017 \\ 0.28613 & -0.00004 \\ 0.30957 & -0.00035 \\ 0.32495 & 0.00003 \\ 0.33276 & -0.00041 \\ 0.37108 & -0.00033 \\ 0.40234 & 0.00020 \\ 0.44848 & -0.00013 \\ 0.51831 & 0.00019 \\ 0.54175 & 0.00009 \\ 0.56494 & 0.00006 \\ 0.60326 & -0.00008 \\ 0.63452 & -0.00023 \\ 0.65721 & -0.00013 \\ 0.68066 & -0.00001 \\ 0.75048 & 0.00004 \\ 0.78931 & 0.00033 \\ 0.83494 & 0.00034 \\ 0.88939 & -0.00011\end{array}$


THE FOLLONING INDEXING IS DN THE BASIS OF THF. HEXAGONAL SYSTEM WITH THE ERROR. LESS THAN 0.000904 THE IJNRESOLVED WAVELENGTH USED WAS 1.54180 AND THE K-ALPHA-ONE WAVELENGTH USED WAS 1.54051 THF DENSITY IS 13.248, THE FORMIJLA WEIGHT IS 178.500, AND THE NUMBER IS 2.001 .

THE FIRST O LINFS ARE UNRE SOLVED. THE REST ARE K-ALPHA-I LINES.

AN FSTIMATE DF THF STANDARD DEVIATION OF SINE SQUARED THETA IS 0.0002

AN ESTIMATE DF THF STANDAPR DEVIATION DF THETA IS 0.0139

AN ESTIMATF OF THE STANDARD DEVIATION OF AIERO IS 0.0153

AN ESTIMATE OF THE STANDARD DFVIATION OF CLERO IS

$\triangle H A T$ IS 0.077393 RHAT IS C.023193

THE LATTICF CONSTANT AZFRT IS 3.19708 ANGSTROMS.

THE LATTICE CONSTANT CZERO IS 5.05776 ANGSTRNMS.

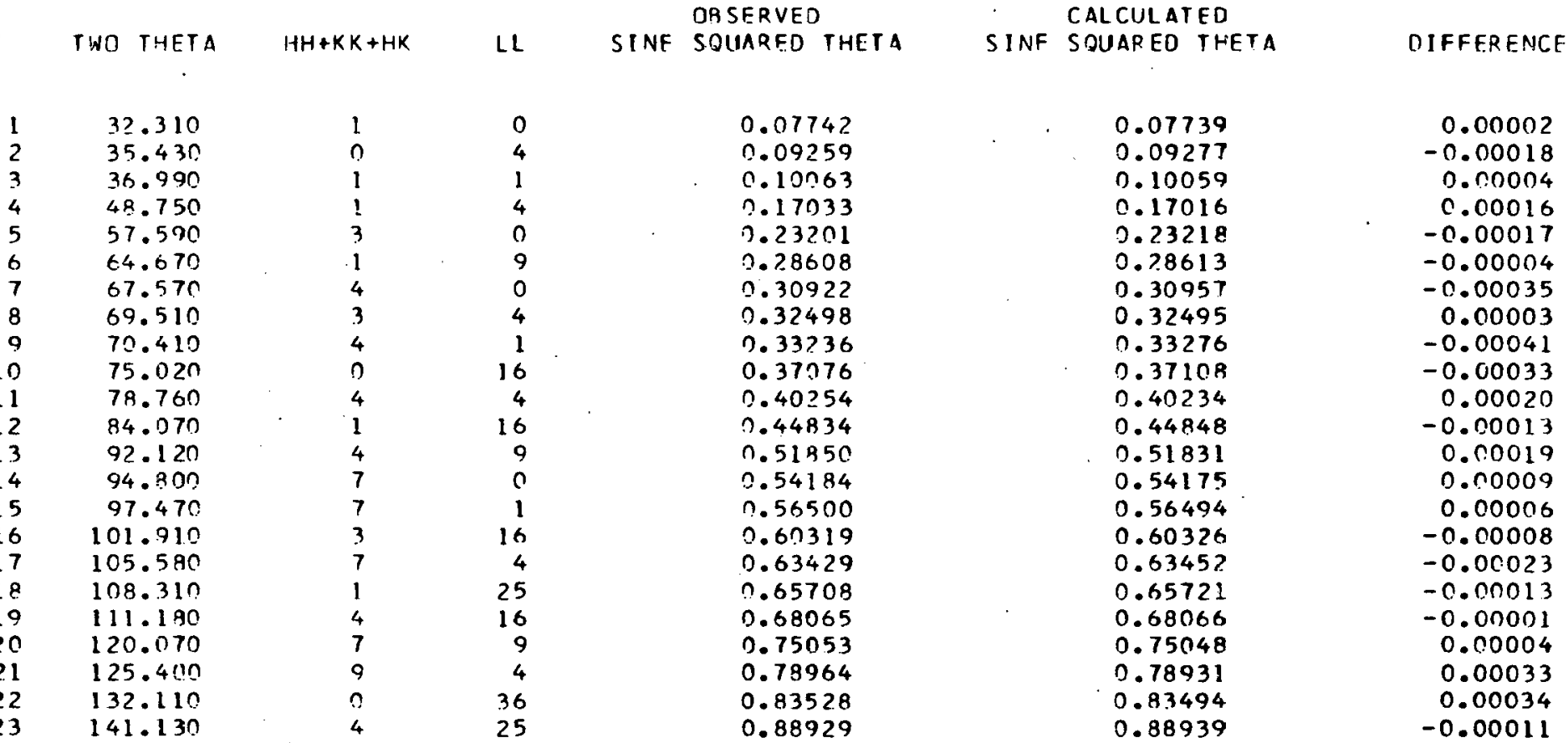


TLE FOLLOWING IVDEXING IS ON THE BASIS OF THE HEXAGONAL SYSTEM WITH THE ERROR LESS THAN O. COO9O4 THE UNRESOLVED WAVELENGTH USE! WAS 1.54180 AND THE K-ALPHA-ONE WAVELENGTH USED WAS 1.54051 THF DENSITY IS 13.248, THF FORMULA WEIGHT IS 178.500, ANO THE NUMBER IS 20.022 .

THE FIRST O LINES ARE UNRESOLVED. THE REST ARE K-ALPHA-1 LINES.

AN ESTIMATE TF THE STANDARI) DEVIATION DF SINE SQUARED THFTA IS 0.0002

AN FSTIMATE OF THE SIANDARD DEVIATION OF THETA IS

AN FSTIMATE OF THE STANDARD DEVIATION OF THETA IS 0.0132

AN FSTIMATE OF THE STANMARD OEVIATINN OF AZERD IS
AN ESTIMATE OF THE STANDARD. DEVIATIINN DF CZERT IS

ALAT IS 0.00773 T BHAT IS 0.023176

THF LATTICE CONSTANT ATFRT IS 10.11056 ANGSTROMS.

THE LATTICE CONSTANT C.ZFPO IS 5.05955 ANGSTROMS.

I TWD THETA HH+KK+HK LL SINF SQUARED THETA SINE SOUAREO THETA

$\begin{array}{ll}1 & 32.310 \\ 2 & 35.430 \\ 3 & 36.990 \\ 4 & 49.750 \\ 5 & 57.590 \\ 6 & 64.670 \\ 7 & 67.570 \\ 8 & 6.9 .510 \\ 9 & 70.410 \\ 10 & 75.020 \\ 11 & 78.760 \\ 12 & 84.070 \\ 13 & 92.120 \\ 14 & 94.800 \\ 15 & 97.470 \\ 16 & 101.910 \\ 17 & 105.580 \\ 18 & 108.310 \\ 19 & 111.180 \\ 20 & 120.070 \\ 21 & 125.400 \\ 22 & 132.110 \\ 23 & 141.130\end{array}$

$\begin{array}{rr}7 & 1 \\ 0 & 4 \\ 13 & 0 \\ 19 & 1 \\ 27 & 1 \\ 25 & 4 \\ 13 & 9 \\ 39 & 1 \\ 16 & 9 \\ 0 & 16 \\ 57 & 0 \\ 31 & 9 \\ 67 & 0 \\ 67 & 1 \\ 73 & 0 \\ 75 & 1 \\ 79 & 1 \\ 37 & 16 \\ 61 & 9 \\ 97 & 0 \\ 75 & 9 \\ 81 & 9 \\ 67 & 16\end{array}$

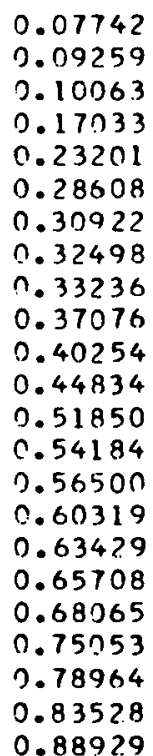

0.07735
0.09271
0.10060
0.17021
0.23212
0.28617
0.30919
0.32498
0.33240
0.37087
0.40240
0.44848
0.51848
0.54166
0.56491
0.50356
0.63452
0.65715
0.58064
0.75063
0.78898
0.83541
0.88930

0.00007 $-0.00012$

0.00003

$0.0 n 112$

$-0.00010$

$-0.00008$

0.00003

$-0.00000$

$-0.00005$

$-0.00006$

0.00014

$-0.00014$

0.00002

0.00018

0.00009

$-0.00038$

$-0.00023$

$-0.00007$

0.00001

$-0.00011$

c. 00067

$-0.00013$

0.8352 .8
0.88929

-0.0000 ? 
EXAMPLE 3. Delta Prime Plutonium (Tetragonal)

The correct lattice parameters are $a_{0}=3.339$ angstroms and $b_{0}=4.446$ angstroms.

Execution time was 68 seconds.

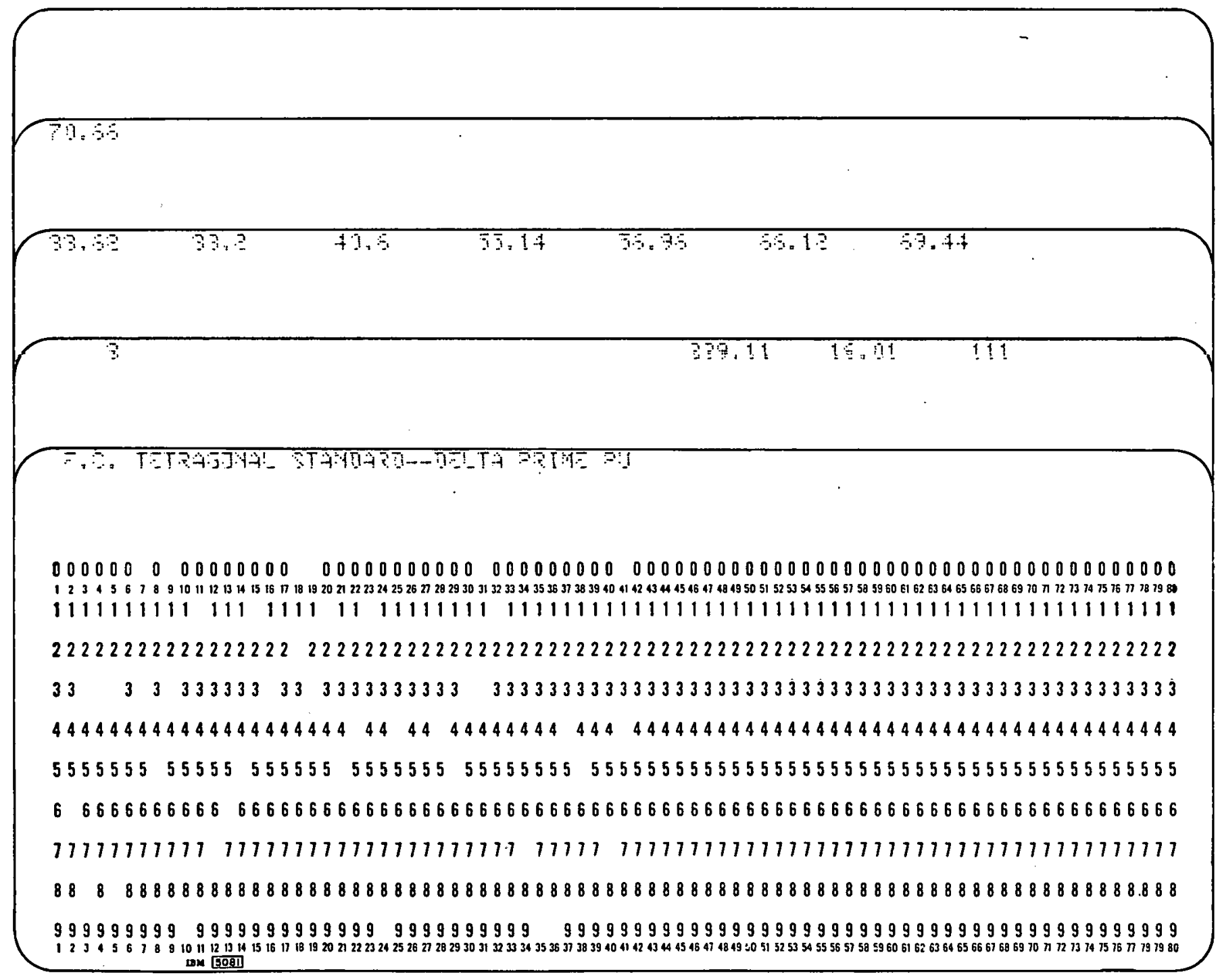

A-10 
THE FOLLOWING INDEXING. IS ON THF BAS:S DF THE TETRAGONAL SYSTEM WITH THE ERROR LESS THAN O.OOQT9I

THE UNRESOLVED WAVELENGTH USED WAS 1.54180 AND THE K-ALPHA-ONE WAVELENGTH USED WAS 1.54051

THF DENSITY IS 16.010, THE FORMULA WFIGHT IS 239.110 , AND THE NUMPER IS 1.990 .

THE FIRST 8 LINES AF:E UNRF SOL VED. THE REST ARE K-ALPHA-I LINES.

AN ESTIMATE OF THF STANDARD DEVIATION OF SINE SQIJARED THETA IS 0.0001

AN FSTIMATE DF THE STANDART DEVIATION DF THETA IS 0.0052

AN FSTIMATE DF THE STANDARD DEVIATION OF AZERO IS 0.0219

AN ESTIMATE TF THE STANDAR! DEVIATION OF CZERO IS 0.0371

AHAT IS 0.053429 BHAT IS 0.030144

THF LATTICE CONSTANT APERN IS 3.33232 ANGSTRMMS.

THE LATTICE CONSTANT CLERO IS $4.4 \div 384$ ANGSTROMS.

I. THAO THETA HH+KK LL SINF SOUARED THETA. SINE SOUAREG THETA

SINF SQUARED THETA - SINE SQUAREI THETA DIFFERENCE

$\begin{array}{ll}1 & 33.620 \\ 2 & 38.200 \\ 3 & 40.600 \\ 4 & 55.140 \\ 5 & 56.960 \\ 6 & 64.120 \\ 7 & 69.440 \\ 8 & 70.660\end{array}$

$\begin{array}{ll}1 & 0.08350 \\ 0 & 0.10689 \\ 4 & 0.12016 \\ 0 & 0.21385 \\ 4 & 0.22701 \\ 1 & 0.29709 \\ 9 & 0.32386 \\ 4 & 0.33385\end{array}$

0.06347

0.10686

$0.1=017$

0.21372

0.22703

0.29710

0.32382

0.00002

0.00003

$-0.00001$

0.00014

$-0.00003$

$-0.00010$

0.00004

$-0.00004$ 
THE FOLLOWING INDEXING IS ON THE BASIS OF THE TETRAGONAL SYSTEM HITH THE ERROR LESS THAN O.004895

THE UNRESILVED WAVELENGTH USED WAS 1.54180 AND THE K-ALPHA-ONE WAVELENGTH USED WAS 1.54051

THE DENSITY IS 16.010, THE FORMULA WEIGHT IS 239.110 . AND THE NUMBER IS 1.990.

THE FIRST 8 LINES ARE UNRESOLVED. THE REST ARE K-ALPHA-I LINES.

AN ESI IMATE OF THE STANDARD DEVIATION OF SINE SOUARED THETA IS 0.0001

AN FSTIMATE OF THE STANDARD DEVIATION OF THETA IS 0.0052

AN ESTIMATE OF THE STANDARD DFVIATION OF AZERO IS 0.0219

AN ESTIMATE OF THE STANDARD DEVIATION OF C.ZERO IS 0.0371

AHAT IS 0.053429 BHAT IS 0.030044

THE LATTICE CONSTANT AZFRO IS 3.33232 ANGSTROMS.

THE LATTICE CONSTANT CZERO IS 4.44384 ANGSTROMS.

\begin{tabular}{|c|c|c|c|c|c|c|c|c|c|}
\hline I & TWO THETA & HH+KK & $\mathbf{L L}$ & SINE & $\begin{array}{l}\text { OBSERVED } \\
\text { SQUARED THETA }\end{array}$ & S INE & $\begin{array}{l}\text { CAL CUL ATED } \\
\text { SOUARED THFTA }\end{array}$ & & DIFFERENCE \\
\hline $\begin{array}{l}1 \\
2 \\
3 \\
4 \\
5 \\
6 \\
7 \\
8\end{array}$ & $\begin{array}{l}33.620 \\
38.200 \\
40.600 \\
55.140 \\
56.960 \\
66.120 \\
69.440 \\
70.660\end{array}$ & $\begin{array}{l}1 \\
? \\
0 \\
4 \\
2 \\
5 \\
1 \\
4\end{array}$ & $\begin{array}{l}1 \\
0 \\
4 \\
0 \\
4 \\
1 \\
9 \\
4\end{array}$ & & $\begin{array}{l}0.08350 \\
0.10689 \\
0.12016 \\
0.21385 \\
0.22701 \\
0.29709 \\
0.32386 \\
0.33385\end{array}$ & $\cdot$ & $\begin{array}{l}0.08347 \\
0.10686 \\
0.12017 \\
0.21372 \\
0.22703 \\
0.29719 \\
0.32382 \\
0.33389\end{array}$ & · & $\begin{array}{r}0.00002 \\
0.00003 \\
-0.00001 \\
0.00014 \\
-0.00003 \\
-0.00010 \\
0.00004 \\
-0.00004\end{array}$ \\
\hline
\end{tabular}


THF FOLLOWING INDEXING IS TN THE BASIS DF THE TETRAGONAL SYSTEM WITH THE ERROP LFSS THAN 0. JCZ448 THE UNRESMLVEN WAVELENGTH USFD WAS 1.54180 AND THE K-ALPHA-ONE WAVELENGTH USFD WAS 1.54051 THE DENSITY IS 16.010. THE FORMULA WFIGHT IS 239.11\%, AND THF NIJMRFR IS 1.990 .

THF FIRST 8 LINES AEE UNRESOLVEO. THE RFST ARE K-ALPHA-I LINES.

AN FSTIMATE TF THE STMNIIARI) DFVIATION TF SINE SQUARED THFTA IS 0.0001

AN FSTIMATE OF THE STAMIORD DFVIATION OF THETA IS

AV FSTIMATE DF THF STAMTARD DTVIATION DF ATERT IS 0.0219

AN ESTIMATF TF THE. STANIMART DEVIATION OF CTERO IS

AHAT IS O. $0534 ? 9$ BHAT IS 0.030044

THF LATTICE CONSTANT AITPI IS 3.33?3? ANGSTRTMS.

THE LATTICF CONSTANT CZFRC IS 4.44334 ANGSTRMMS.

I THO THETA. HHFKK LL SINF SQUARED THETA SINE SOUARET THFTA

SINE SOUARET. THFTA DIFFERENCE

$\begin{array}{ll}1 & 33.620 \\ 2 & 39.200 \\ 3 & 40.600 \\ 4 & 55.140 \\ 5 & 55.960 \\ 6 & 66.120 \\ 7 & 69.440 \\ 9 & 79.560\end{array}$

2

$$
\begin{aligned}
& 1 \\
& 0 \\
& 4 \\
& 5 \\
& 4 \\
& 1 \\
& 9 \\
& 4
\end{aligned}
$$

0.03350
0.12589
0.12716
0.21385
0.22701
0.29709
0.32386
0.33385

0.08347

?. 15626

$0.1<017$

0.21372

$0.2 \div 703$

$0.2 \subseteq 719$

0.35382

ก. $3 \equiv 389$

0.00002

0.00003

$-0.00001$

C.r.no14

$-0.00003$

$-0.00010$

0.00004

$-0.00004$ 
THE FOLLOWING INDEXING IS DN THE BASIS DF THE TFTRAGONAL SYSTEM HITH THE ERROR LESS THAN O.OOL2Z4

THE IJNRESOLVED WAVELFNGTH USED WAS 1.54180 AND THE K-ALPHA-ONE HAVELENGTH USED WAS L.54051 THE DENSITY IS 16.010, THE FORMIJLA WEIGHT IS 239.110 . AND THE NUMBER IS 1.990.

THE FIRST 8 LINES ARE UNRESOLVED. THE REST ARE K-ALPHA-1 LINES .

AN ESTIMATE DF THE STANDARD DEVIATION DF SINE SOUARED THETA IS 0.0001

AN ESTIMATF OF THE STANDARD DEVIATION DF THETA IS $0.005 ?$

AN ESTIMATE OF THE STANIARD DEVIATION DF AZERD IS 0.0219

AN ESTIMATE OF THE STANIARD DFVIATION OF CZERD IS 0.0371

AHAT IS 0.053429 BHAT IS 0.030044

THF LATTICE CONSTANT ARERO IS 3.33232 ANGSTROMS.

THE LATTICE CONSTANT CZERT IS 4.44384 ANGSTROMS.

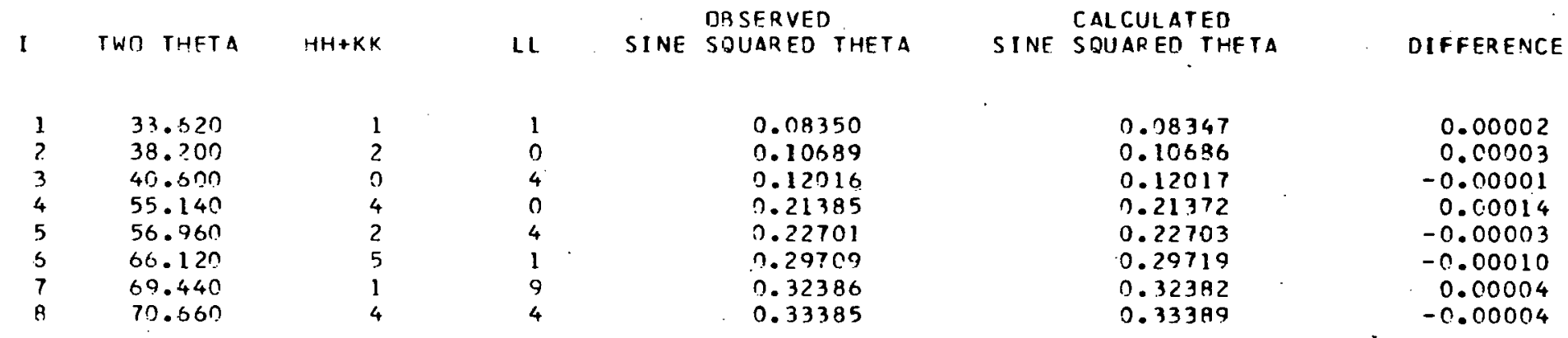


THE FOLLOWING INDEXING IS TN THE BASIS OF THE TETRAGONAL SYSTEM WITH THE ERROR LESS THAN O. DOOGI 2

THE UNRFSTLVED WAVELENGTH USE WAS 1.54180 ANO THE K-ALPHA-ONE hAVELENGTH USED WAS 1.54051

THE DENSITY IS 16.010, THE FORMULA WEIGHT IS 239.110. AND THE NUMBER. 15 1.990.

THE FIRST 9 LINES ARE UNRFSOLVFD. THE REST ARE K-ALPHA-1 LINES.

AN ESTIMATE TF THE STANDARD DEVIATION DF SINE SQUARED THFTA IS 0.0001

AN ESTIMATE OKF THE STANDARD DFVIATION OF THETA IS 0.0052

AN ESTIMATE OF THE STANDARD DEVIATION DF AZERT IS 0.0219

AN ESTIMATE DF THF STAVDARO DFVIATION OF C.ZERD IS

AHAT IS 0.053429 BHAT IS $0.030044^{\circ}$

THF LATTICE CONSTANT AZFRO IS 3.33237 ANGSTROMS.

THE IATTICF CONSTANT CIERO IS 4.44384 ANGSTROMS.

I THO THETA HH+KK DL LASERVED

$\begin{array}{lll}1 & 33.620 & 1 \\ 2 & 38.200 & 2 \\ 3 & 40.600 & 0 \\ 4 & 55.140 & 4 \\ 5 & 56.960 & ? \\ 6 & 66.120 & 5 \\ 7 & 69.440 & 1 \\ 8 & 70.660 & 4\end{array}$

SINE SOUARED THETA

$$
\begin{aligned}
& 0.08350 \\
& 0.10589 \\
& 0.12016 \\
& 0.21385 \\
& 0.22701 \\
& 0.29709 \\
& 0.32386 \\
& 0.33335
\end{aligned}
$$

C.AL CUL ATFD SINE SOUAREI THETA

DIFFFRENCE
0.00002

0.00003

$-0.00001$

0.00014

$-0.00003$

$-0.00012$

0.00004
-0.00004 
THF FOLLONING INDEXING IS ON THE BASIS OF THE TETRAGONAL SYSTEA WITH THE ERROR LESS THAN O.0OO6I2

THE UNRESDL VED HAVELENGTH USFD WAS 1.54180 AND THE K-ALPHA-ONE haVELENGTH USED HAS L.54051 THE DENSITY IS 16.310. THE FORMULA WEIGHT IS 239.110. AND THE NUMBER IS 1.990.

THE FIRST 8 LINES ARE UNRESOL VEO. THE REST ARE K-ALPHA-1 LINES.

AN ESTIMATE OF THE STANDARD DEVIATION OF SINE SQUARED THETA IS 0.0001

AN FSTIMATE OF THE STANDARD DEVIATION OF THETA IS

AN FSTIMATE OF THE STANDARD DEVIATION OF AZERO IS 0.0219

AN ESTIMATE OF THF. STANDARD DFVIATION OF CZERO IS 0.0371

AHAT IS: 0.053429 BHAT IS 0.030044

THE LATTICE CONSTANT AZFRD IS 3.33232 ANGSTROMS.

THE LATTICE CONSTANT CZERO IS 4.44384 ANGSTROMS.

\begin{tabular}{|c|c|c|c|c|c|c|c|c|}
\hline I & TWD THETA & $H H+K K$ & $\mathbf{L L}$ & SINE & $\begin{array}{l}\text { OBSERVED } \\
\text { SOUARED THETA }\end{array}$ & S INE & $\begin{array}{l}\text { CALCULATED } \\
\text { SOUARED THETA }\end{array}$ & DIFFERENCE \\
\hline $\begin{array}{l}1 \\
2 \\
3 \\
4 \\
5 \\
6 \\
7 \\
8\end{array}$ & $\begin{array}{l}33.620 \\
38.200 \\
40.600 \\
55.140 \\
56.960 \\
66.120 \\
69.440 \\
70.660\end{array}$ & $\begin{array}{l}1 \\
2 \\
0 \\
4 \\
2 \\
5 \\
1 \\
4\end{array}$ & $\begin{array}{l}1 \\
0 \\
4 \\
0 \\
4 \\
1 \\
9 \\
4\end{array}$ & & $\begin{array}{l}0.08350 \\
0.10689 \\
0.12016 \\
0.21385 \\
0.22701 \\
0.29709 \\
0.32386 \\
0.33385\end{array}$ & & $\begin{array}{l}0.08347 \\
0.10686 \\
0.12017 \\
0.21372 \\
0.22703 \\
0.29719 \\
0.32382 \\
0.33389\end{array}$ & $\begin{array}{r}0.00002 \\
0.00003 \\
-0.00001 \\
0.00014 \\
-0.00003 \\
-0.00010 \\
0.00004 \\
-0.00004\end{array}$ \\
\hline
\end{tabular}


THE FOLLOWING INDEXITN, IS ON THE RASIS OF THE TETRAGONAL SYSTFM WITH THE ERROR LESS THAN O.OOOGI 2

THE UNRESOLVED WAVELENGTH IJSED WAS 1.54180 AND THE K-ALPHA-ONE WAVELFNGTH USED hAS 1.54051

THE OCNSITY IS 16.010. THF FRRMULA NEIGHT IS 239.110 , AND THE NUMBER IS 11.940.

THE FIRST \& LINFS ARE UNRESOLVED. THE REST ARF K-ALPHA-I LINES.

AN ESTIMATE DF THE $S$ ANDART DEVIATIDN DF SINE SOUARED THETA IS 0.0706

AN ESTIMATF OF THE STANIARD DEVIATIDN DF THETA IS 0.0034

AN ESTIMATE OF THF STANDARD DEVIATION OF AZERח IS 0.0247

AN ESTIMATE TFF THE STANDARD DEVIATION DF CZFRI IS 0.1100

AHAT IS 0.02672 ? BHAT IS 0.003336

THF LATTICF CONSTAVT AZERD IS 4."II9I ANGSTROMS.

THE LATTICE CONSTANT CZFRO IS 13.33519 ANGSTROMS.

\begin{tabular}{|c|c|c|c|c|c|c|c|c|}
\hline I & TWO THETA & $H H+K K$ & LL & SINE & $\begin{array}{l}\text { OASERVED } \\
\text { SOUARED THETA }\end{array}$ & SINE & $\begin{array}{l}\text { CALCULATFD } \\
\text { SQUARE) THETA }\end{array}$ & DIFFERENCE \\
\hline 1 & 33.620 & 2 & 9 & & 0.08350 & & 0.03347 & 0.00002 \\
\hline 2 & 39.200 & 4 & 0 & & 0.10689 & & 0.10689 & 0.00000 \\
\hline 3 & 40.500 & $n$ & 36 & & 0.12016 & & 0.12011 & 0.00005 \\
\hline 4 & 55.140 & 8 & 0 & & 0.21385 & & $0.2: 378$ & $0.0 \cap 008$ \\
\hline 5 & 56.960 & 4 & 36 & & 0.22701 & & 0.22700 & 0.00001 \\
\hline 6 & 60.120 & 5 & 49 & & 0.29709 & & 0.29709 & -0.00000 \\
\hline 7 & $69.44 \%$ & 9 & 25 & & 0.32386 & & 0.32391 & -0.00005 \\
\hline 8 & 70.660 & 8 & 36 & & 0.33385 & & 0.33389 & -0.00003 \\
\hline
\end{tabular}


EXAMPLE 4. Ice III (Orthorhombic)

The lattice parameters are $a_{o}=1020$ angstroms, $b_{o}=5.87$ angstroms, and $c_{0}=7.17$ angstroms .

Execution time was 199 seconds.

79.95

64.94

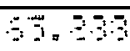

37.94

$89,7+1$

71.713

74.193

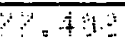

45.117

93.797

74,79

9.995

$79,127.99,49$

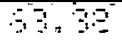

$24 \div 5145$

39.4775

$7+131$

75,153

39.5735

45.515

47.21

1. 1.

1.

11

ISIII

00000000000000000000000000000000000000000000000000000000000000000000000000000000

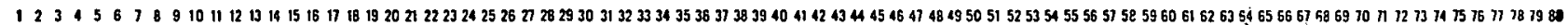
11111111111111111111111111111111111111111111111111111111111111111111111111111111

22222222222222222222222222222222222222222222222222222222222222222222222222222222

3 333333333333333333333333333333333333333333333333333333333333333333333333333333 44444444444444444444444444444444444444444444444444444444444444444444444444444444 5555555555555555555555555555555555555555555555555555555555555555555555555555555

66666666666666666666666666666666666666666666666666666666666666666666666666666666

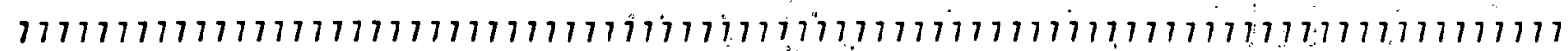
88888888888888888888888888888888888888888888888888888888888888888888888888888888

999 9999999999999999999999999999999999999999999999999999999999999999999999999

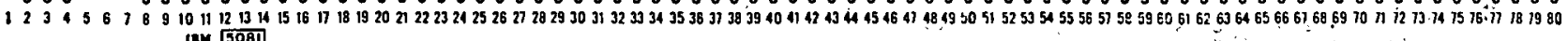
IIM [0.01] 
ICE II I

THE FILLDWING INDEXING IS ON THE BASIS OF THE ORTHORHOMBIC SYSTFM WITH THE ERROR LESS THAN O.04055O

THF LATTICE CONSTANT ATERO IS

3.79319 ANGSTROMS.

THE LATTICE CONSTANT RZFRO IS 2.89702 ANGSTROMS.

THE LATIICE CONSTANT CZERO IS 2.46885 ANGSTROMS.

THE UNRESOLVED WAVELENGTH USED WAS 1.54180 AND THE K-ALPHA-ONE WAVELENGTH USED WAS 1.54051

THE DENSITY IS 1.000 THE FORMULA WEIGHT IS 18.000 , AND THE NUMBER IS 0.91.

THE FIPST O LINES ARE UNRESOLVED. THE REST ARF K-ALPHA-1 LINES.

AN ESTIMATE DF THE STANDARD DEVIATION DF THETA IS 1.02680

AN ESTIMATE TF THE STAMDARD DEVIATION OF SINE SQUARED THETA IS 0.01420

AN ESTIMATE DF THE STANDARD DEVIATION OF AZERO IS 0.04864

AN ESTIMATE DF THE STANIDARD DFVIATION OF RZERO IS 0.03520

AN ESTIMATE OF THE STANDARD DEVIATIDN DF C.ZERO IS 0.03696

KK OBSERVED CALCULATED

$\begin{array}{rrrllllr}1 & 24.81459 & 1 & 0 & 0 & 0.04616 & 0.04123 & 0.00493 \\ 2 & 30.47749 & 0 & 1 & 0 & 0.06909 & 0.07069 & -0.00161 \\ 3 & 34.13100 & 0 & 0 & 1 & 0.08612 & 0.09734 & -0.01122 \\ 4 & 35.16299 & 0 & 1 & 0 & 0.09124 & 0.07069 & 0.02055 \\ 5 & 39.59349 & 1 & 1 & 0 & 0.11471 & 0.11193 & 0.00278 \\ 6 & 43.51599 & 1 & 0 & 1 & 0.13741 & 0.13857 & -0.00116 \\ 7 & 47.26099 & 0 & 1 & 1 & 0.16067 & 0.16803 & -0.00736 \\ 8 & 49.11699 & 4 & 0 & 0 & 0.17274 & 0.16494 & 0.00780 \\ 9 & 50.89899 & 0 & 1 & 1 & 0.18466 & 0.20926 & 0.01663 \\ 10 & 54.75200 & 1 & 1 & 1 & 0.21144 & 0.23563 & 0.00218 \\ 11 & 56.50499 & 4 & 1 & 0 & 0.22407 & 0.26227 & -0.01156 \\ 12 & 58.12700 & 4 & 0 & 1 & 0.23598 & -0.02629 \\ 13 & 60.46599 & 4 & 1 & 0 & 0.25353 & 0.26227 & 0.01790 \\ 14 & 63.31999 & 4 & 0 & 1 & 0.27550 & 0.28277 & 0.01322 \\ 15 & 04.04900 & 0 & 4 & 0 & 0.28120 & 0.26227 & -0.00157 \\ 16 & 65.28799 & 4 & 0 & 1 & 0.32400 & 0.02870 \\ 17 & 67.84499 & 1 & 4 & 0 & 0.29097 & 0.33297 & -0.01256 \\ 18 & 68.94099 & 4 & 1 & 1 & 0.31144 & 0.32400 & -0.01263 \\ 19 & 71.31799 & 1 & 4 & 0 & 0.32034 & 0.37111 & 0.01584 \\ 20 & 74.10899 & 9 & 0 & 0 & 0.33984 & 0.38935 & -0.00801 \\ 21 & 77.40199 & 0 & 0 & 4 & 0.36310 & 0.42134 & 0.00160 \\ 22 & 79.96799 & 1 & 4 & 1 & 0.39095 & & -0.00844\end{array}$

EXECUTION TIME $\quad 2.8 .17 \mathrm{SEC}$.

IHC210I PROGRAM INTERRUPTKPD OLD PSW IS FF0500008201860E OREISTFR CONTAINED OOOOOOOO 


\section{文 ICE III}

THE FOLLOWING INDEXING IS DN THE BASIS OF THE ORTHORHOMBIC SYSTEM WITH THE ERROR LESS THAN O.O2OZTS THE LATTICE CONSTANT AZERO IS

THE LATTICE CONSTANT BZFRO IS 4.61049 ANGSTROMS. 3.06272 ANGSTRQMS.

THE UNRESOLVED WAVELENGTH USED WAS 1.54180 AND THE K-ALPHA-ONE HAVELENGTH USED WAS 1.54051 THE DEVSITY IS 1.030 THE FORMULA WEIGHT IS 18.000 , ANO THE NUMBER IS 1.73 .

THE FIRST C LINES ARE UNRESOLVED. THE REST ARE K-ALPHA-1 LINES.

AN ESTIMATE CF THE STANDARD DFVIATION DF THETA IS 0.51426

AN ESTIMATE CF THE STANDARD DEVIATION OF SINE SQUARED THETA IS 0.00636

AN ESTIMATE GF THE STANDARD DEVIATION OF AZERO IS

AN FSTIMATE CIF THE STANDARD DEVIATION OF BIERO IS 0.04345

AN ESTIMATE TIF THE STANDARD DEVIATIINN OF CZERO.IS 0.02022

OBSERVED CALCULATED

I TWO THETA HH KK LL SINE SOUARED THETA SINE SOUAREO THET

$\begin{array}{ll}1 & 24.81459 \\ 2 & 30.47749 \\ 3 & 34.13100 \\ 4 & 35.16299 \\ 5 & 39.59349 \\ 6 & 43.51599 \\ 7 & 47.26099 \\ 8 & 49.11699 \\ 9 & 50.89899 \\ 10 & 54.75200 \\ 11 & 56.50499 \\ 12 & 58.12700 \\ 13 & 60.46599 \\ 14 & 63.31999 \\ 15 & 64.04900 \\ 16 & 65.28799 \\ 17 & 67.84499 \\ 18 & 68.94099 \\ 19 & 71.31799 \\ 20 & 74.10899 \\ 21 & 77.40199 \\ 22 & 79.96799\end{array}$

EXECUTION TIME $\quad 31.45$ SEC.

IHC?LIOI PROGRAM INTERRUPTEPQ OLD PSW IS

$\begin{array}{lr}0.04424 & 0.00192 \\ 0.06325 & 0.00584 \\ 0.07215 & 0.01397 \\ 0.09116 & 0.00008 \\ 0.10749 & 3.00722 \\ 0.13540 & 0.00201 \\ 0.15588 & 0.00479 \\ 0.17489 & -0.00215 \\ 0.17696 & 0.00769 \\ 0.20487 & 0.00657 \\ 0.21913 & 0.00493 \\ 0.24021 & -0.00423 \\ 0.25300 & 0.00053 \\ 0.26812 & 0.00737 \\ 0.28091 & 0.00029 \\ 0.28861 & 0.00236 \\ 0.31445 & -0.00301 \\ 0.32515 & -0.00481 \\ 0.35186 & -0.01201 \\ 0.36464 & -0.00154 \\ 0.39817 & -0.00722 \\ 0.40888 & 0.00402\end{array}$


ICE II I

THE FOLLOWING INDEXING IS ON THF

THF LATTICE CONSTAVT AZERO IS

BASIS OF THE ORTHORHOMBIC SYSIEM WITH THE ERROR LESS THAN 5.96719 ANG STROMS.

THF LATTICE CONSTANT BLERO IS

5.09124 ANGSTROMS.

THE LATTICE CONSTANT CIFRO IS

3.55584 ANGSTROMS.

THE UNRESOLVE WAVELENGTH USED WAS 1.54180 AND THE K-ALPHA-ONE WAVELENGTH USEO WAS 1.54051

THE DEVSITY IS 1. DOO THE FORMULA WEIGHT IS 18.000 . AND THE NUMBFR IS 3.61.

THE FIRST 0 LINES ARE UNRESOLVFD. THE REST APE K-ALPHA-1 LINES.

AN ESTIMATE OF THE STANDARD DFVIATION OF .THFTA IS 0.15323

A.Y FSTIMAIE OF THE SIANDARD DEVIATION DF SINE SOUARED THETA IS 0.0022

AN ESTIMATE DF THE STANDARD DEVIATION OF AZERO IS 0.01593

AN ESTIMATE IF THE STANDARD DEVIATION DF RZERO IS 0.01031

AN ESTIMATE NTF THE STANDARD DFVIATINN DF CIERO IS 0.00875
CALCULATFD
I TWN THETA HH KK LL SINF SQUARED THETA SINE SQUAREC THETA
DIFFER ENTE

OBSER VED

$\begin{array}{ll}1 & 24.81459 \\ 2 & 30.47749 \\ 3 & 34.13100 \\ 4 & 35.14299 \\ 5 & 39.59349 \\ 6 & 43.51 .599 \\ 7 & 47.26099 \\ 8 & 49.11699 \\ 9 & 50.89899 \\ 10 & 54.75200 \\ 11 & 56.50499 \\ 12 & 58.12700 \\ 13 & 60.46599 \\ 14 & 63.31999 \\ 15 & 64.04900 \\ 16 & 65.28799 \\ 17 & 67.84499 \\ 18 & 63.94099 \\ 19 & 71.31799 \\ 20 & 74.10899 \\ 21 & 77.40199 \\ 22 & 79.96799\end{array}$

$\begin{array}{rrr}0 & 0 & 1 \\ 0 & 1 & 1 \\ 1 & 1 & 1 \\ 4 & 1 & 0 \\ 4 & 0 & 1 \\ 0 & 4 & 1 \\ 4 & 4 & 0 \\ 9 & 1 & 0 \\ 0 & 0 & 4 \\ 0 & 1 & 4 \\ 1 & 9 & 0 \\ 9 & 4 & 0 \\ 0 & 9 & 1 \\ 4 & 1 & 4 \\ 0 & 4 & 4 \\ 9 & 4 & 1 \\ 16 & 0 & 1 \\ .4 & 0 & 1 \\ 3 & 0 & 4 \\ 9 & 1 & 4 \\ 0 & 9 & 4 \\ 0 & 16 & 1\end{array}$

0.04616
0.06909
0.08612
0.09124
0.11471
0.13741
0.16067
0.17274
0.19466
0.21144
0.22407
0.73598
0.25353
0.27550
0.28120
0.29097
0.31144
0.32034
0.33984
0.36310
0.39095
0.41290

0.04692
0.06981
0.08647
0.08954
0.11357
0.13848
0.15820
0.17295
0.18769
0.21058
0.22266
0.24151
0.25292
0.27723
0.27925
0.28844
0.31352
0.31957
0.33765
0.36054
0.39369
0.41314

$-0.00076$

$-0.000 .73$

$-0.0 n n 35$

-0.00135
0.00170

0.00114

$-0.00107$

0.00247

$-0.00011$

-0.00011
-0.00304

0.05304
0.00086

0.00141

$-0.00553$

0.00061

$-0.00173$

0.00195

0.00253

$-0.0020 ?$

$0.0007 ?$

0.00219

0.00256

0.00256
-0.00274

0.41290

0.39369
0.41314

$-0.000 ? 4$

EXECUTION TIMF 36.16 SEC.

IHR 2 INI PRDGRAM INTERRUPTYPA OLD PSW IS

FF0500008201860E

REGISIEP CONTAINED

00000000 
THE FOLLOWING INDEXING IS ON THE EASIS DF THE ORTHORHOMBIC SYSTEM WITH THE ERFOR LESS THAN O.GOSOG9 THE LATTICE CONSTANT AZERO IS 21.13641 ANGSTRDMS.

THE LATTICE CONSTANT BIERD IS 3.59529 ANGSTRIMS.

THE LATTICE CONSTANT CZERO IS 5.23065 ANGSTRDMS.

THE INRESTLV $\equiv$ WAVELENGTH USED HAS 1.54180 ANO THE K-ALPHA-ONE WAVELENGTH USED WAS 1.54051

THF DENSITY IS 1.000 . THE FORMULA. WEIGHT IS 18.000 . AND THE NIJMAER IS $13.3 \mathrm{C}$.

THE FIRST D LINES ARE IINRESDL VE[I. THE REST ARE K-ALPHA-1 LINES.

AN ESTIMATE DF THE STAPDAR? DEVIATION OF THETA IS 0.04926

AN ESTIMATE NF THF STANDAR? DEVIATION OF SINE SQUARED THETA IS 0.00066

AN ESTIMATE DF THF. STAPDARD DEVIATION OF AZFRO IS 0.03948

AN ESTIMATE DF THE STAHDARD DEVIATION OF BIEQO IS 0.00206

AN ESTIMATE DF THE STAHDARD DEVIATION DF C.ZERO IS 0.00646

I TWD THETA HH KK LL SINE SOUARED THETA SINE SOUAREDTHE

\begin{tabular}{|c|c|c|c|c|c|c|c|}
\hline $\mathbf{I}$ & 7.4 .81 .59 & 0 & 1 & 0 & 0.04516 & 0.04590 & 0.00027 \\
\hline 2 & 30.47749 & 1 & 1 & 1 & 0.06909 & 0.06891 & 0.00017 \\
\hline 3 & 34.13100 & 0 & 0 & 4 & 0.08512 & 0.08674 & -0.00002 \\
\hline 4 & $35.16 \geq 99$ & 4 & 0 & 4 & 0.09124 & 0.09205 & -0.00081 \\
\hline 5 & 39.59349 & 36 & 1 & 1 & 0.11471 & 0.11539 & -.0 .00069 \\
\hline 6 & 43.51599 & 4 & 1 & 4 & 0.13741 & 0.13795 & -0.00054 \\
\hline 7 & 47.26099 & 121 & 0 & 0 & 0.16067 & 0.16059 & -0.00002 \\
\hline 8 & 49.11599 & 64 & 0 & 4 & 0.17274 & 0.17173 & 0.00101 \\
\hline 9 & 50.89899 & 1 & 4 & $n$ & 0.18466 & 0.18492 & -0.00027 \\
\hline 10 & $54.75 ? 00$ & 4 & 4 & 1 & 0.21144 & 0.21059 & 0.00085 \\
\hline 11 & 56.50499 & 169 & 0 & 0 & 0.22407 & 0.22444 & -0.00037 \\
\hline 12 & 58.12700 & 144 & 1 & 0 & 0.23598 & 0.23713 & -0.00115 \\
\hline 13 & 60.46599 & 36 & 4 & 1 & 0.25353 & 0.25309 & 0.00044 \\
\hline 14 & 63.31799 & 4 & 4 & 4 & 0.27550 & 0.27565 & -0.00015 \\
\hline 15 & 64.049 ก & 196 & $n$ & 1 & 0.28120 & 0.28198 & -0.00078 \\
\hline 16 & 65.23779 & 91 & 4 & 0 & 0.29097 & 0.29117 & -0.00019 \\
\hline 17 & 67.84499 & 169 & 0 & 4 & 0.31144 & 0.31118 & 0.000 .77 \\
\hline 18 & 68.94 .799 & 2.25 & 0 & 1 & 0.32 .034 & 0.32049 & -0.00016 \\
\hline 19 & 71.31799 & 255 & 0 & 0 & 0.33984 & 0.33997 & $-0.00 C 13$ \\
\hline $2 n$ & 74.10399 & 256 & 0 & 1 & 0.36310 & 0.36166 & 0.00144 \\
\hline 21 & 77.40199 & 9 & 4 & 9 & 0.39 .795 & 0.39071 & $0.00 \cap 23$ \\
\hline 22 & 79.96799 & $n$ & 9 & 0 & 0.41290 & 0.41309 & -0.00019 \\
\hline
\end{tabular}

EXECUTION TIMF $\quad 44.50 \mathrm{SEC}$. 
ICE III

THE FDLLOWING IND=XING IS TN THE BASIS OF THE ORTHORHOMBIC SYSTEM WITH THE ERROR LESS THAN O.OO2534 THE LATTICE CONSTINT. AZERO IS 3.59543 ANGSTROMS.

THF LATTICE CONSTANT BZERO IS 17.78845 ANGSTROMS.

THE IJNRESDLVED WAVELENGTH USED WAS 1.54180 ANO THE K-ALPHA-DNE WAVELENGTF USED HAS 1.54052

THE DEVSITY IS 1.000 THE FRRMULA WEIGHT IS 18.000, AND THE NUMBER IS 1.1.3?.

THE FIRST O LINES ARE UNRFSOLVFD. THE REST ARF K-ALPHA-1 LINES.

AN ESTIMATE OF THE STANDARD DEVIATION DF THETA IS O.)5B43

AN ESTIMATF OF THE STANDARD DEVIATION DF SINE SOUARED THETA IS 0.00082

AN ESTIMATE DF TH= STANIARD DEVIATION OF AZERO IS 0.02267

AN ESTIMATE DF THE STANDARD DEVIATION DF BZERO IS 0.01270

AN ESTIMATE OF THE STANDARD DEVIATION RF CIERO IS 0.07463

DRSFRVED CALCULATED

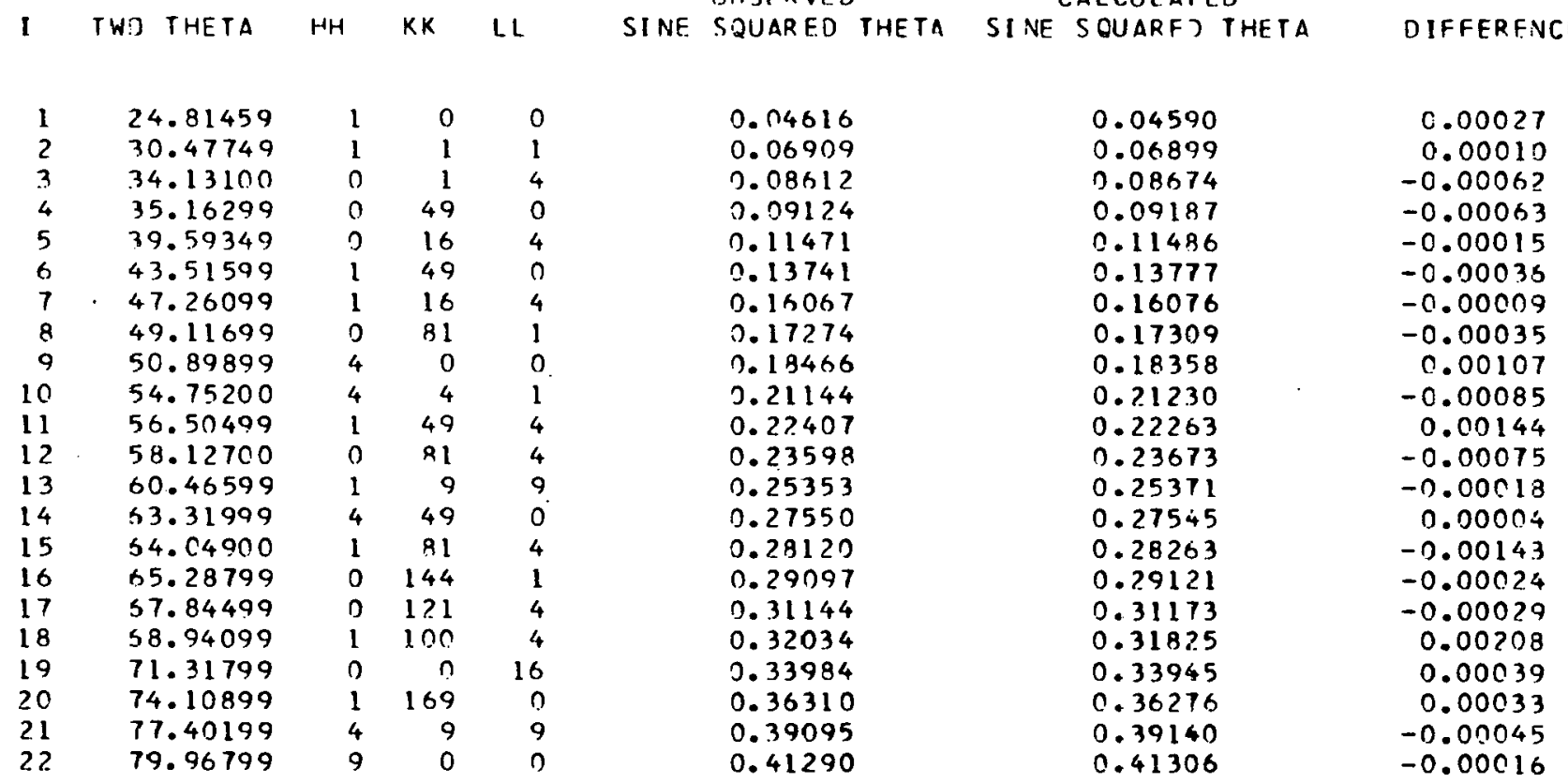

EXECUTION TIME $53.53 \mathrm{SEC}$.

IHC $210 I$ PROGRAM INTERRUPTEPO OLD PSH IS

FF05000D8201860E

REGISTER CONTAINED

00000000 
THF LATTISF CONSTANT AIERT IS 10.1998 A ANGSTRJMS.

\begin{tabular}{l} 
THF LATTICE CONSTANT RZFRO IS \\
THE LATIICE CONSTANT CTIFRO IS \\
\hline .86994
\end{tabular}

THE UNRESTLVEO WAVELENGTH USEN WAS 1.54180 AND THE K-ALPHA-ONE WAVELENGTH USED WAS 1.54051 THF DENSITY IS 1.030 THE FORMULA WEIGHT IS 18.000 , AND THF NUMBER IS $14.3 \mathrm{H}$.

THE FIRST ? LINFS ARE UNRESTLVED. THE REST ARE K-ALPHA-1 LINES.

AN ESTIMATE DF THE STAMDAR! DEVIATIDN DF THETA IS 0.00016

AN FSTIMATE OF THF STAIMARD DEVIATION OF SINF SJUARED THETA IS 0.00000

AN ESTIMATE TF THE STAMIDARD DEVIATION OF AZERT IS 0.00003

AN ESTIMATE DF THE STAPIDARD DEVIATION DF BZERO IS * 0.00001

AN FSTIMATE OF THE STAHARD DEVIATIOM OF CIERT IS 0.03001

OBSERVED
I TWM THFTA HH KIK LL SINE SOUARED THETA SINE SOUARED THETA

$\begin{array}{rrrrr}1 & 24.81459 & 0 & 4 & 0 \\ 2 & 30.47749 & 1 & 4 & 1 \\ 3 & 34.13100 & 1 & 1 & 4 \\ 4 & 35.16299 & 16 & 0 & 0 \\ 5 & 39.59349 & 9 & 4 & 1 \\ 6 & 43.51599 & 16 & 4 & 0 \\ 7 & 47.26099 & 1 & 0 & 9 \\ 8 & 49.11599 & 0 & 9 & 4 \\ 9 & 50.89399 & 0 & 16 & 0 \\ 10 & 54.75200 & 25 & 0 & 4 \\ 11 & 56.50409 & 9 & 9 & 4 \\ 12 & 58.12700 & 9 & 16 & 0 \\ 13 & 50.46599 & 9 & 16 & 4 \\ 14 & 63.31799 & 9 & 0 & 16 \\ 15 & 64.04700 & 1 & 0 & 16 \\ 16 & 55.28799 & 49 & 1 & 0 \\ 17 & 67.84499 & 1 & 25 & 1 \\ 19 & 68.94799 & 36 & 4 & 4 \\ 19 & 71.31799 & 9 & 25 & 0 \\ 20 & 74.10399 & 1 & 25 & 4 \\ 21 & 77.40199 & 9 & 16 & 9 \\ 22 & 79.96799 & 16 & 4 & 16\end{array}$

[IFFERENCE

EXECUTION TIME 109. 32 SEC.

$$
\begin{aligned}
& 0.04616 \\
& 0.06909 \\
& 0.08612 \\
& 0.09124 \\
& 0.11471 \\
& 0.13741 \\
& 0.16967 \\
& 0.17274 \\
& 0.18466 \\
& 0.21144 \\
& 0.22497 \\
& 0.23598 \\
& 0.25353 \\
& 0.27550 \\
& 0.28120 \\
& 0.29097 \\
& 0.31144 \\
& 0.32034 \\
& 0.33994 \\
& 0.36310 \\
& 0.39995 \\
& 0.41290
\end{aligned}
$$

0.00000

0.00000

0.00000

$-0.00000$

0.00000

.0 .00000

0.00000

0.00000

0.00000

0.00000

0.00000

0.00000

0.00000

0.00000

ก. 00000

$-0.00000$

0.00000

0.00000

$-0.00000$

$-0.00000$

0.00000

$-0.00000$

IHC?IOI PQOGRAM IOTERREPTYPA OLD PSW IS 
ICE II I

THE FOLLOWING INDEXING IS ON THE BASIS OF THE ORTHORHOMBIC SYSTEM. WITH THE ERROR. LESS THAN O.0OOG34

THE LATTICE CONSTANT AZERO IS 10.19988 ANGSTROMS

THF LATTICE CONSTAVT BIFRO IS 7.16994 ANGSTROMS.

THE LATTICE CONSTINT CIERO IS 5.86998 ANGSTROMS.

THF IJNRESOLVED WAJELENGTH USED WAS 1.54180 ANO THE K-ALPHA-ONE WAVELENGTH USED WAS 1.54051 THE DEVSITY IS 1.000 THE FORMULA WEIGHT IS 18.000, AND THE NUMBER IS 14.36.

THF FIRST O LIN=S ARF UNRESOLVED. THE REST ARE K-ALPHA-1 LINES.

AN ESTIMATE DF THE STANMAR? DEVIATION OF THETA IS 0.00016

AN ESTIMATE DF THE STANDART DEVIATION OF SINE SQUARED THETA IS 0.00000

AN ESTIMATE OF THE STANDART DEVIATION OF AZERO IS 0.00003

AN ESTIMATE OF THE STANDART DEVIATION DF BLERO IS 0.00001

AN ESTIMATE OF THE STANIART DFVIATION OF CLFRD IS 0.00001

I THO THETA HH KK LL SINF SQUARED THETA SINE SQUARED THETA DIFFERENCE

$\begin{array}{rrrrrrrr}1 & 24.81459 & 0 & 4 & 0 & 0.04616 & 0.04616 & 0.00000 \\ 2 & 30.47749 & 1 & 4 & 1 & 0.06909 & 0.06908 & 0.00000 \\ 3 & 34.13100 & 1 & 1 & 4 & 0.08612 & 0.08612 & 0.00000 \\ 4 & 35.16299 & 16 & 0 & 0 & 0.09124 & 0.09124 & -0.00000 \\ 5 & 39.59349 & 9 & 4 & 1 & 0.11471 & 0.11471 & 0.00000 \\ 6 & 43.51599 & 16 & 4 & 0 & 0.13741 & 0.13741 & 0.00000 \\ 7 & 47.26099 & 1 & 0 & 9 & 0.16067 & 0.160 .57 & 0.00000 \\ 8 & 49.11699 & 0 & 9 & 4 & 0.17274 & 0.18465 & 0.00000 \\ 9 & 50.89899 & 0 & 16 & 0 & 0.18466 & 0.21144 & 0.00000 \\ 10 & 54.75200 & 25 & 0 & 4 & 0.21144 & 0.22407 & 0.00000 \\ 11 & 56.50499 & 9 & 9 & 4 & 0.22407 & 0.23598 & 0.00000 \\ 12 & 58.12700 & 9 & 16 & 0 & 0.23598 & 0.25353 & 0.00000 \\ 13 & 60.46599 & 0 & 16 & 4 & 0.25353 & 0.27550 & 0.00000 \\ 14 & 63.31999 & 0 & n & 16 & 0.27550 & 0.29097 & 0.00000 \\ 15 & 54.04900 & 1 & 0 & 16 & 0.28120 & 0.31144 & 0.00000 \\ 16 & 65.28799 & 49 & 1 & 0 & 0.29097 & 0.32033 & 0.00000 \\ 17 & 67.84499 & 1 & 75 & 1 & 0.31144 & 0.33995 & 0.00000 \\ 18 & 68.94099 & 36 & 4 & 4 & 0.32034 & 0.36310 & 0.00000 \\ 19 & 71.31799 & 9 & 25 & 0 & 0.33984 & 0.39094 & -0.00000 \\ 20 & 74.10899 & 1 & 25 & 4 & 0.36310 & 0.41290 & 0.00000 \\ 21 & 77.40199 & 9 & 16 & 9 & 0.39095 & 0.00000 \\ 22 & 79.96799 & 16 & 4 & 16 & 0.41290 & & -0.00000\end{array}$

FXELUTIDN TIME 154.19 SEC.

IHC?IOI PROGRAM IVTERRUPIgPa OLO PSW IS 
ICE III

THE FOLLOWING INDEXING IS DN THE BASIS OF THE ORTHORHOMBIC SYSTEM WITH THE ERROR LESS THAN 0.000634 THE LATTICE CONSTANT AZERO IS 10.19988 ANGSTROMS.

THE LATTICE CONSTANT RZERO IS 7.16994 ANGSTROMS.

THE LATTICE CONSTANT LZERO IS 5.86998 ANGSTROMS.

THE UNRESOLVED WAVELENGTH USED WAS 1.54180 AND THE K-ALPHA-ONE WAVELENGTH USED HAS 1.54051 THE DENSITY IS 1.000 THE FDRMULA. HEIGHT IS 18.000, AND THE NUMBER IS 14.36 .

THE FIRST O LINES ARE UNRE SOL Ved. THE REST ARE K-ALPHA-1 LINES.

AN ESTIMATE DF THE STA VIARD DEVIATION OF THETA IS 0.00016

AN ESTIMATE DF THE STA VDARD DEVIATION OF SINE SQUARED THETA IS 0.00000

AN ESTIMATE TF THE STA VIARD DEVIATIDN OF AZERO IS 0.00003

AN ESTIMATE DF THE STAVIDARD DEVIATION OF BLERI IS 0.00001

AN FSTIMATE DF THE STANDARD OEVIATION OF CZERn IS 0.00001

I TWR THETA OBSERVED CALCULATED

I TWM THETA HH KK LL SINE SQUARED THETA SINE SQUARED THETA OIFFERENCE

\begin{tabular}{|c|c|c|c|c|c|c|c|c|}
\hline 1 & 24.81459 & 0 & 4 & 0 & & 0.04616 & 0.04616 & $0.000 n 0$ \\
\hline 2 & 30.47749 & 1 & 4 & 1 & & 0.06909 & 0.06908 & 0.00000 \\
\hline 3 & 34.13100 & 1 & 1 & 4 & & 0.08612 & 0.08612 & 0.000100 \\
\hline 4 & 35.16299 & 16 & 0 & 0 & & 0.09124 & 0.09124 & -0.000100 \\
\hline 5 & 39.59349 & 9 & 4 & 1 & & 0.11471 & 0.11471 & 0.00000 \\
\hline 6 & 43.51599 & 16 & 4 & 0 & & 0.13741 & 0.13741 & 0.00000 \\
\hline 7 & 47.26099 & 1 & 0 & 9 & & 0.16067 & 0.16067 & .0 .00000 \\
\hline 8 & 49.11599 & 0 & 9 & 4 & & 0.17274 & 0.17274 & 0.00000 \\
\hline 9 & 50.89399 & 0 & 16 & 0 & & 0.13466 & 0.18465 & 0.00000 \\
\hline 10 & 54.75200 & 25 & 0 & 4 & & 0.21144 & 0.21144 & 0.00000 \\
\hline 11 & 56.50499 & 9 & 9 & 4 & & 0.22407 & 0.22407 & 0.00000 \\
\hline 12 & 58.12700 & 9 & 16 & $n$ & & $0.2359 \mathrm{~B}$ & 0.23598 & 0.00000 \\
\hline 13 & 60.46599 & 0 & 16 & 4 & & 0.25353 & 0.25353 & 0.00000 \\
\hline 14 & 63.31999 & 0 & 0 & 16 & & 0.27550 & 0.27550 & 0.00000 \\
\hline 15 & 64.047800 & l & 0 & 16 & : & 0.28120 & 0.28120 & 0.00000 \\
\hline 16 & 65.28799 & 49 & 1 & 0 & & 0.29097 & 0.29097 & -0.00000 \\
\hline 17 & $67.84 \div 99$ & l & 25 & 1 & & 0.31144 & 0.31144 & 0.00000 \\
\hline 18 & 58.94099 & 36 & 4 & 4 & & 0.32034 & 0.32033 & 0.00000 \\
\hline 19 & 71.31799 & 9 & 25 & 0 & & 0.33984 & 0.33985 & -0.00000 \\
\hline 20 & 74.10899 & 1 & 25 & 4 & & 0.36310 & 0.36310 & -0.00000 \\
\hline 21 & 77.40199 & 9 & 16 & 9 & & 0.39095 & 0.39094 & 0.00000 \\
\hline 22 & 79.96799 & 16 & 4 & 16 & & 0.41290 & 0.41290 & -0.00000 \\
\hline
\end{tabular}

EXECUTION TIME $199 .: 6 \mathrm{SEC}$. 
EXAMPLE 5. Magnesium Silicate $\left(\mathrm{Mg}_{2} \mathrm{SiO}\right)$ (Orthorhom bic)

The correct lattice parameters are $a_{o}=4.7524$ angstroms, $b_{o}=5.9853$ angstroms, and $c_{o}=10.213$ angstroms. Execution time was 144 seconds.

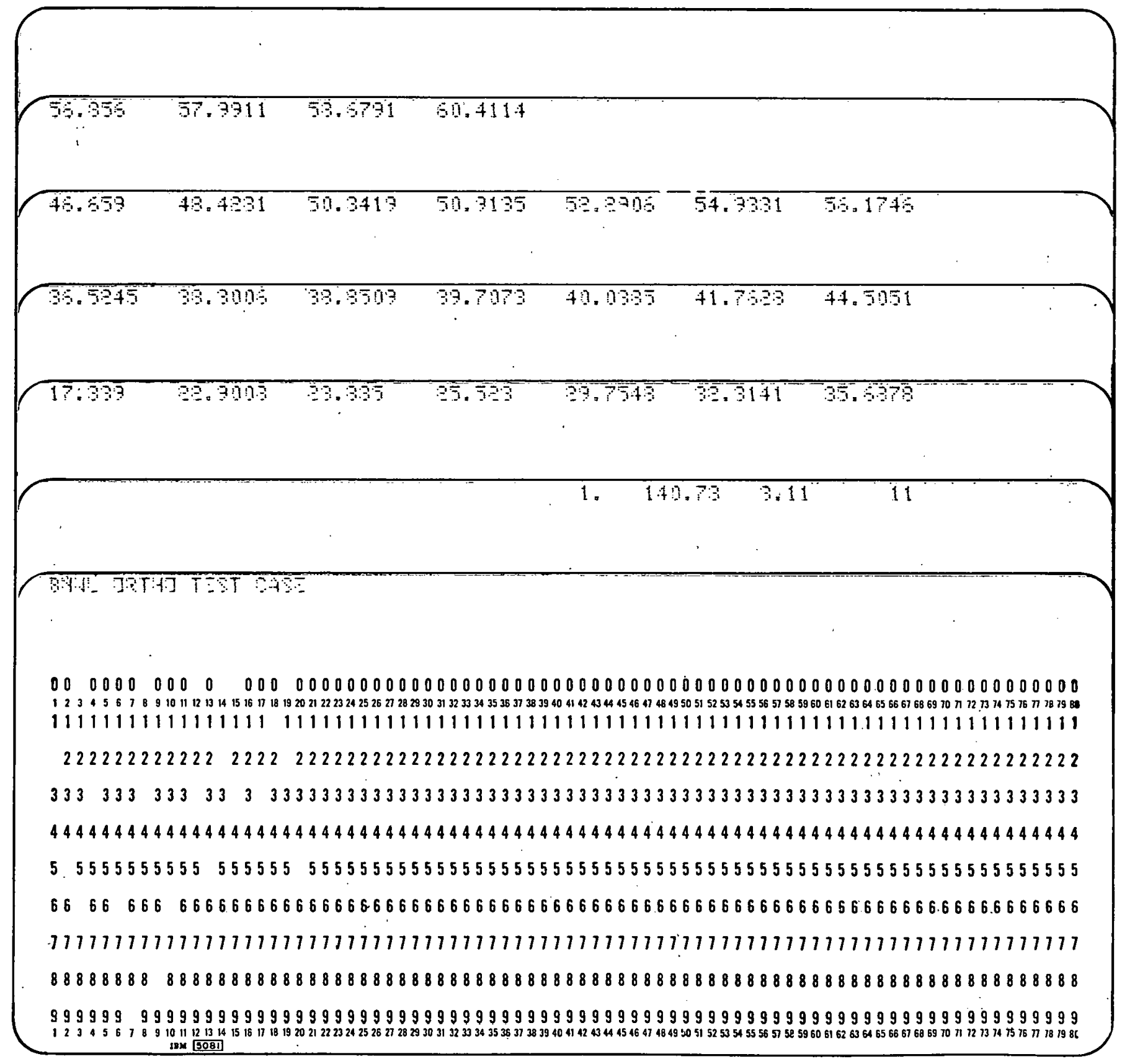


THE FDLLOWING INDEXING IS ON THE BASIS DF THE ORTHORHOMBIC SYSTEM WITH THE ERROR LESS THAN O.OL4GT5

THE LATTICE CONSTANT AIERO IS

5.12133 ANGSTROMS.

THE LATTICE CONSTANT BZERO IS 13.91784 ANGSTROMS.

THE LATTICE CONSTANT CIERO IS 3.90160 ANGSTROMS.

THE UNRESOLVED WAVELENISTH USED MAS 1.54180 AND THE K-ALPHA-ONE HAVELENGTH USED WAS 1.54051

THE OENSITY IS 3.110 THE FORMULA HEIGHT IS 140.730. AND THE NUMBER IS 3.70.

THE FIRST 0 LINES ARE UNRESOLVED. THE REST ARE K-ALPHA-I LINES.

AN EST IMATE OF THE STAMDARD DEVIATION DF THETA IS 0.10996

AN ESTIMATE OF THE STANOARO DEVIATION OF SINE SOUARED THETA IS

AN ESTIMATE OF THE STANDARD DEVIATION OF AZERO IS 0.01148

AN ESTIMATE OF THE STANDARO DEVIATION OF BIERO IS 0.02127

AN ESTIMATE OF THE STANDARD DEVIATION OF CZERO IS 0.00250

I THO theta HH KK Ll. SINE SOUARED theta SINE SOUARED theta

OIFFER ENCE

$\begin{array}{ll}1 & 17.33899 \\ 2 & 22.90079 \\ 3 & 23.83499 \\ 4 & 25.52299 \\ 5 & 29.75479 \\ 6 & 32.31409 \\ 7 & 35.68779 \\ 8 & 36.52449 \\ 9 & 38.30060 \\ 10 & 38.85089 \\ 11 & 39.70729 \\ 12 & 40.03850 \\ 13 & 41.76279 \\ 14 & 44.50510 \\ 15 & 46.65900 \\ 16 & 48.42809 \\ 17 & 50.34189 \\ 18 & 50.91350 \\ 19 & 52.29059 \\ 20 & 54.93309 \\ 21 & 56.17459 \\ 22 & 56.85599 \\ 23 & 57.99109 \\ 24 & 58.67909 \\ 25 & 60.41139\end{array}$

$\begin{array}{rr}1 & 0 \\ 0 & 0 \\ 0 & 1 \\ 0 & 16 \\ 1 & 1 \\ 0 & 25 \\ 4 & 1 \\ 1 & 25 \\ 0 & 36 \\ 1 & 16 \\ 0 & 25 \\ 4 & 9 \\ 4 & 0 \\ 4 & 4 \\ 4 & 9 \\ 0 & 4 \\ 1 & 1 \\ 0 & 9 \\ 0 & 64 \\ 1 & 49 \\ 1 & 64 \\ 1 & 16 \\ 0 & 64 \\ 4 & 49 \\ 9 & 16\end{array}$

0
1
1
0
1
0
0
0
0
1
1
0
1
1
1
4
4
4
0
1
0
4
1
0
0

0.02272
0.03941
0.04264
0.04879
0.06592
0.07743
0.09390
0.09820
0.10761
0.11061
0.11534
0.11719
0.12705
0.14341
0.15683
0.16822
0.18090
0.18475
0.19417
0.21273
0.22167
0.22663
0.23497
0.24008
0.25312

0.02262
0.03897
0.04204
0.04901
0.06466
0.07657
0.09354
0.09919
0.11026
0.11060
0.11555
0.11805
0.12946
0.14171
0.15702
0.16815
0.18158
0.18346
0.19602
0.21167
0.21864
0.22753
0.23500
0.24056
0.25259

0.00010

0.00044

$-0.00021$

0.00126

0.00086

0.00035

$-0.00099$

$-0.00265$

0.00001

$-0.00021$

$-0.00085$

$-0.00241$

0.00170

$-0.00019$

0.00007

$-0.00069$

0.00129

$-0.00185$

0.00106

0.00303

$-0.00090$

$-0.00002$

$-0.00048$

0.00052 
RNWL ORTHO TEST CASE

THF FOLLOWING INDEXING IS DN THE BASIS OF THE ORTHORHOMBIC SYSTEM WITH THE FRROR LFSS THAN O.OTI337

THE LATTICE CINSTANT AZFRO IS

5.12133 ANGSTROMS.

THE LATTICE CONSTINT BZERO IS 13.91784 ANGSTROMS.
THE LATTICE CONSTINT CZERE IS 3.90160 ANCSTROMS.

THF UNRESTLVFO WA'JFLENGTH USED WAS 1.54180 AND THE K-ALPHA-IINE WAVFI.ENGTH USED WAS 1.54051

THE DEVSITY IS 3.110 THE FDPMULA WEIGHT IS 140.730 , AND THF NUMBER IS 3.70 .

THE FIRST O LINES ARF UNRESTLVED. THE REST $\triangle R E$ K-AL. PHA-1 LINES.

AN ESTIMATE DF THE STANMART DEVIATION DF THETA IS 0.10996

AN ESTIMATE OF THE STANITARI DEVIATINN OF SINE SQUARED THFTA IS 0.00131

AN ESTIMATE OF THE. STANIARD DEVIATION DF AZERO IS 0.01148

AN FSTIMATE TF THF STANIARI DFVIATION OF BIERT IS 0.02127

AN ESTIMATE DF THF. STANDAPD DEVIATION OF CZERO IS, $0.0025 ?$

I TWC THETA HH KK LL SINF SQUARED THETA SINE SOUAPFD THET

SINF SQUARED THETA SINE SOUAPFD THFTA DIFFERENCE

$\begin{array}{rrrllrr}17.33899 & 1 & 0 & 0 & 0.02272 & 0.02262 & 0.00010 \\ 22.90079 & 0 & 0 & 1 & 0.03941 & 0.03897 & 0.00044 \\ 23.83499 & 0 & 1 & 1 & 0.04264 & 0.04204 & 0.00061 \\ 25.52299 & 0 & 16 & 0 & 0.04879 & 0.04901 & -0.000 ? 1 \\ 29.75479 & 1 & 1 & 1 & 0.06592 & 0.06466 & 0.00126 \\ 32.31409 & 0 & 25 & 0 & 0.07743 & 0.07657 & 0.00086 \\ 35.68779 & 4 & 1 & 0 & 0.09390 & 0.09354 & 0.00035 \\ 36.52449 & 1 & 25 & 0 & 0.09820 & 0.09919 & -0.00099 \\ 38.30060 & 0 & 36 & 0 & 0.10761 & 0.11026 & -0.00265 \\ 38.85089 & 1 & 16 & 1 & 0.11061 & 0.11060 & 0.00001 \\ 39.70729 & 0 & 25 & 1 & 0.11534 & 0.11555 & -0.00021 \\ 40.03850 & 4 & 9 & 0 & 0.11719 & 0.12946 & -0.00085 \\ 41.76279 & 4 & 0 & 1 & 0.12705 & 0.14171 & -0.00241 \\ 44.50510 & 4 & 4 & 1 & 0.14341 & 0.15702 & 0.00170 \\ 46.65900 & 4 & 9 & 1 & 0.15683 & 0.16815 & -0.00019 \\ 48.42809 & 0 & 4 & 4 & 0.16822 & 0.18158 & 0.00007 \\ 50.34189 & 1 & 1 & 4 & 0.18090 & 0.18346 & -0.00040 \\ 50.91350 & 0 & 9 & 4 & 0.18475 & 0.19602 & 0.00129 \\ 52.29059 & 0 & 64 & 0 & 0.19417 & 0.21137 & -0.0018 .5 \\ 54.93309 & 1 & 49 & 1 & 0.21273 & 0.21864 & 0.0106 \\ 56.17459 & 1 & 64 & 0 & 0.22167 & 0.22753 & 0.00303 \\ 56.85599 & 1 & 16 & 4 & 0.22663 & 0.23500 & -0.00090 \\ 57.99109 & 0 & 64 & 1 & 0.23497 & 0.24056 & -0.00002 \\ 58.67909 & 4 & 49 & 0 & 0.24008 & 0.25259 & -0.00048 \\ 60.41139 & 9 & 16 & 0 & 0.25312 & & 0.00052\end{array}$


B BNHL. ORTHO TEST CASE

THE FOLL OWING INDEXING IS ON THE

THE LATTICE CONSTANT AZERT IS

THE LATTICE CONSTANT BIERO IS

THE LATTICE CONSTANT CLERO IS

5.50461 ANGSTROMS.

13.86447 ANG STROMS.

THE IJNRESOLVEn HAVELENGTH USED HAS 1.54180 AND THE K-ALPHA-ONE HAVELENGTH USED HAS 1.54051

THE DENSITY IS 3.110 THE FORMULA WEIGHT IS 140.730, AND THE NUMAER. IS 4.0 .0$.

THE FIRST 0 LINES ARE UNRESUEVED. THE REST ARE K-ALPHA-1 LINES.

AN ESTIMATE OF THE STANDARD DEVIATION OF THETA IS 0.11674

AN ESTIMATE DF THE STANDARD DEVIATION OF SINF. SQUARED THETA IS 0.00122

AN ESTIMATE OF THE STANDARD DEVIATION DF AZERO IS 0.00799

AN ESTIMATE OF T.HE STANOARD DFVIATION OF BZERO IS

0.00799

0.00759

OBSERVED CALCULATED

I TWM THETA HH KK LL SINE SOUARED THETA SINE SQUARED THETA

DIFFER ENCE

$\begin{array}{rrrrr}1 & 17.33899 & 1 & 1 & 0 \\ 2 & 22.90079 & 0 & 0 & 1 \\ 3 & 23.83499 & 0 & 1 & 1 \\ 4 & 25.52299 & 1 & 9 & 0 \\ 5 & 29.75479 & 0 & 9 & 1 \\ 6 & 32.31409 & 0 & 25 & 0 \\ 7 & 35.68779 & 4 & 4 & 0 \\ 8 & 36.52449 & 1 & 25 & 0 \\ 9 & 38.30060 & 1 & 16 & 1 \\ 10 & 38.85089 & 0 & 36 & 0 \\ 11 & 39.70729 & 0 & 25 & 1 \\ 12 & 40.03850 & 4 & 0 & 1 \\ 13 & 41.76279 & 4 & 16 & 0 \\ 14 & 44.50510 & 4 & 9 & 1 \\ 15 & 46.65900 & 0 & 1 & 4 \\ 16 & 48.42809 & 1 & 36 & 1 \\ 17 & 50.34189 & 9 & 1 & 0 \\ 18 & 50.91350 & 1 & 4 & 4 \\ 19 & 52.29059 & 4 & 25 & 1 \\ 20 & 54.93309 & 9 & 0 & 1 \\ 21 & 56.17459 & 1 & 16 & 4 \\ 22 & 56.85599 & 9 & 16 & 0 \\ 23 & 57.99109 & 4 & 1 & 4 \\ 24 & 58.67909 & 9 & 9 & 1 \\ 25 & 60.41139 & 9 & 25 & 0\end{array}$

$$
\begin{aligned}
& 0.02272 \\
& 0.03941 \\
& 0.04264 \\
& 0.04879 \\
& 0.06592 \\
& 0.07743 \\
& 0.09390 \\
& 0.09820 \\
& 0.10761 \\
& 0.11061 \\
& 0.11534 \\
& 0.11719 \\
& 0.12705 \\
& 0.14341 \\
& 0.15683 \\
& 0.16822 \\
& 0.18090 \\
& 0.18475 \\
& 0.19417 \\
& 0.21273 \\
& 0.22167 \\
& 0.22663 \\
& 0.23497 \\
& 0.24008 \\
& 0.25312
\end{aligned}
$$$$
\begin{aligned}
& 0.02267 \\
& 0.03827 \\
& 0.04136 \\
& 0.04736 \\
& 0.06605 \\
& 0.07716 \\
& 0.09067 \\
& 0.09674 \\
& 0.11723 \\
& 0.11111 \\
& 0.11543 \\
& 0.11659 \\
& 0.12770 \\
& 0.14437 \\
& 0.15617 \\
& 0.16896 \\
& 0.17931 \\
& 0.18501 \\
& 0.19375 \\
& 0.21449 \\
& 0.22205 \\
& 0.22560 \\
& 0.23449 \\
& 0.24227 \\
& 0.25338
\end{aligned}
$$

0.00005

0.00114

0.00129

0.00144

$-0.00013$

0.00027

0.00323

0.00033

0.00050

-0.00050
-0.00009

-0.00009
0.00050

$-0.00060^{\circ}$

$-0.00096$

0.00066

$-0.00074$

0.00159

$-0.00026$

0.00042

$-0.00176$

$-0.00038$

D. 00102

$0.0004 E$

$-0.00210$ 
BNWL ORTHO TEST CASE

THE FOLLOWING INDEXING IS DN THF BASIS IF THE ORTHOPHOMHIC SYSTFM WITH THE FRROR LESS THAN O.ODI834

THE LATTICE CONSTAVT AZFRO IS

6.27274 ANGSTROMS.

THE LATTICE CONSTANT RZFRO IS

5.10133 ANGSTROMS.

THE LATTICF CONSTANT C.ZFRO IS 22.12798 ANGSTROMS.

THE UNRESOLVED WAVELENGTH USED WAS 1.54180 AND THE K-ALPHA-ONE WAVELFNGTH USED WAS 1.54051

THE DENSITY IS 3.110 THE FORMULA WEIGHT IS 140.730, AND THF NUMBEP IS 9.4?.

THE FIRST $O$ LINES ARE UNRESOLVFD. THE REST ARF K-ALPHA-1 LINES.

AN FSTIHATE OF THF STANDARD DEVIATION DF THETA IS. 0.03371

$A^{A}$ ESTIMATE DF THE STANDAPD REVIATION OF SINF SQUARED THFTA IS 0.0003C

AN ESTIMATE OF THF STANDARD DEVIATION OF AIFRD IS 0.00660

AN ESTINATE OF THE STANDARD DEVIATION DF BZERT IS 0.00143

AN ESTIMATE DF THF STANDARD DEVIATICN MF CTERO IS 0.01143

I TWD THETA HH KK LL SINE SQUARED THETA SINE SQUIAREN THFTA

DIFFEP ENCE

$\begin{array}{rrrr}17.33809 & 0 & 1 & 0 \\ 22.90079 & 1 & 1 & 1 \\ 23.83499 & 1 & 1 & 4 \\ 25.57299 & 1 & 1 & 9 \\ 29.75479 & 4 & 0 & 4 \\ 32.31409 & 0 & 0 & 64 \\ 35.68779 & 4 & 1 & 9 \\ 36.52449 & 0 & 0 & 81 \\ 38.30060 & 1 & 4 & 1 \\ 38.85089 & 0 & 4 & 16 \\ 39.70729 & 1 & 1 & 64 \\ 40.03850 & 1 & 4 & 9 \\ 41.76279 & 4 & 1 & 36 \\ 44.57510 & 0 & 1 & 100 \\ 46.65900 & 4 & 4 & 14 \\ 48.42809 & 0 & 4 & 64 \\ 50.34199 & 4 & 1 & 81 \\ 50.91350 & 1 & 1 & 121 \\ 52.29059 & 4 & 4 & 36 \\ 54.93309 & 1 & 1 & 144 \\ 56.17459 & 1 & 9 & 1 \\ 56.85599 & 9 & 4 & 0 \\ 57.99109 & 4 & 0 & 144 \\ 58.67909 & 1 & 9 & 16 \\ 60.41139 & 1 & 4 & 121\end{array}$

0.02272
0.03941
0.04264
0.04879
0.05592
0.07743
0.09390
0.09820
0.10761
0.11061
0.11534
0.11719
0.12705
0.14341
0.15683
0.16822
0.18090
0.19475
0.19417
0.21273
0.22167
0.22663
0.23497
0.24008
0.25312

0.02280
0.03929
0.04272

0.04272

0.04878

0.06516

0.07755

$0.094 \div 2$

0.09815

0.10748

0.11058

0.11542

0.11718

0.12673

0.14397

0.15635

0.16874

0.18126

0.18449

c. 10513

0.21236

0.22147

0.22690

0.23479

0.239 .65

$0.2528 B$

-0.00008
0.00032
-0.00008
0.00001
0.00076
-0.00011
-0.00012
0.00005
0.00013
0.00003
-0.00008
0.00007
0.00031
-0.00056
0.00048
-0.00052
-0.00036
0.00026
-0.00096
0.00038
0.00019
-0.00027
0.00018
0.00044
0.00023


BNWL DRTHO TEST CASE

THE FOLLOHING INDEXING IS ON THE BASIS OF THE ORTHORHOMBIC SYSTEM HITH THE ERROR LESS THAN O.OOOSIT THE LATTICE CONSTANT AZERO IS

THE LATTICE CONSTANT BLERC IS

5.98530 ANGSTROMS.

10.21133 ANGSTROMS

THE UNRF.SOLVED WAVELENGTH USED WAS 1.54180 ANO THE K-ALPHA-ONE HAVELENGTH USED HAS 1.54051 THE DEVSITY IS 3.110 THE FORMULA WEIGHT IS 140.730, AND THE NUMBFR IS 7.74 .

THE FIRST 0 LINES ARF UNRESOLVFD. THE REST ARE K-ALPHA-I LINES.

AN ESTIMATE OF THE STANDARD DEVIATION OF THETA IS

AN ESTIMATE TF THE STANDARD DEVIATION OF SINE SQUARED THFIA IS 0.00024

AN ESTIMATE OF THE STANDARD DEVIATION TF AZERO IS 0.00249

AN FSTIMATE OF THE STANDARD DEVIATION DF BZERO IS 0.00163

AN ESTIMATE DF THE STANDARD DEVIATION OF CZERT IS 0.00436

I THO THETA HH KK Ll SINE SOUARFD THETA SINE SOUARED The

\begin{tabular}{|c|c|c|c|c|c|c|c|}
\hline 1 & $\begin{array}{l}17.33899 \\
22.9 n n 79\end{array}$ & 1 & $\frac{1}{4}$ & $\begin{array}{l}0 \\
0\end{array}$ & $\begin{array}{l}0.0227 ? \\
0.03941\end{array}$ & $\begin{array}{r}0.02225 \\
0.03932\end{array}$ & $\begin{array}{l}0.00047 \\
0.00009\end{array}$ \\
\hline 3 & 23.83499 & 1 & 0 & 4 & 0.04264 & 0.04281 & -0.00017 \\
\hline 4 & 25.52799 & 1 & 1 & 4 & 0.04879 & 0.04850 & 0.00029 \\
\hline 5 & 29.75479 & 1 & 4 & 4 & 0.06592 & 0.06557 & $0.00 \cap 35$ \\
\hline 6 & $32.314 ? 9$ & 0 & 9 & 4 & 0.07743 & 0.07746 & -0.00002 \\
\hline 7 & 35.68779 & 1 & 9 & 4 & 0.09390 & 0.09402 & -0.00012 \\
\hline 8 & 36.52449 & 1 & 4 & 9 & 0.09820 & 0.09838 & -0.00018 \\
\hline 9 & 38.300 .50 & 1 & 16 & 0 & 0.10761 & 0.10 .760 & 0.00002 \\
\hline 10 & 38.850 .79 & ? & 1 & 16 & 0.11061 & 0.11068 & -0.00008 \\
\hline 11 & $39.707 \geq 9$ & 4 & 4 & 4 & 0.115 .34 & 0.11525 & 0.00009 \\
\hline 12 & 40.03850 & $?$ & 16 & 4 & 0.11719 & 0.11729 & -0.00009 \\
\hline 13 & 41.76279 & 1 & 1 & 16 & 0.12705 & 0.12725 & $-0.00 \div 20$ \\
\hline 14 & 44.50510 & 4 & 9 & 4 & 0.14341 & 0.14370 & -0.00030 \\
\hline 15 & 46.65900 & 4 & 16 & ? & 0.15633 & 0.15728 & -0.00045 \\
\hline 16 & 48.42809 & 0 & 25 & 4 & 0.16922 & 0.16850 & -0.00028 \\
\hline 17 & 50.34189 & 9 & 1 & 4 & 0.19090 & 0.18099 & $-0.00 \cap 09$ \\
\hline 18 & 50.91350 & 1 & 25 & 4 & 0.18475 & 0.18506 & -10.00030 \\
\hline 19 & 52.29059 & 4 & 4 & 16 & 0.19417 & 0.19400 & 0.00017 \\
\hline 20 & 54.93309 & 1 & 16 & 16 & 0.21273 & 0.21259 & 0.00014 \\
\hline 21 & 56.17459 & 1 & 36 & 0 & 0.22167 & 0.22140 & 0.00027 \\
\hline 22 & 56.85599 & 9 & 9 & 4 & 0.22663 & 0.22651 & 0.00012 \\
\hline 2.3 & 57.99109 & 4 & 25 & 4 & 0.23497 & 0.23474 & 0.00023 \\
\hline 24 & 58.67909 & 3 & 16. & 0 & 0.24008 & 0.24009 & -0.00001 \\
\hline 25 & 60.41139 & 4 & 4 & 25 & 0.25312 & 0.25306 & 0.00006 \\
\hline
\end{tabular}


BNWL MQTHC TEST CASF.

THF FOLL OWING INDEXING IS IIN THE BASIS RF THE CRTHIRHOMBIC SYSTFM WITH THE ERROR LESS THAN O.OOJ9IT

THE LATTICE CONSTANT ALERO IS 5.98530 ANSS STRDMS.

THF I AITICE CONSTANT CIFRO IS 9.50845 ANGSTROMS.

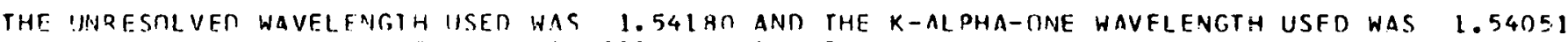
THF TENSITY IS 3.1 IN THE FORMULA WEITHT IS 140.730, AND THE NUMRER IS 7.74 .

THE FIRST O LINES AOF UMRF SRLVED. THE REST ARE K-ALPHA-I LINES.

AN FSIIMAIE DF THF STANMARO OFVIATION DF THFTA IS 0.0276 I

AN FSIIMATF ITF THF TIANIIARI DFVIATION DF SINE SOIJARED THFTA IS $0.000 ?$

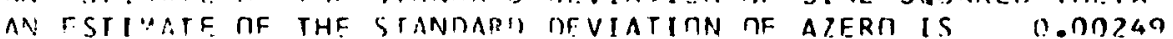

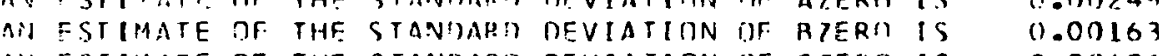

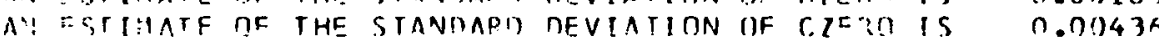

CALCUTATED

\begin{tabular}{|c|c|c|c|}
\hline 1 & 17.33899 & 1 & 1 \\
\hline 2 & 22.90079 & 1 & 4 \\
\hline 3 & ?3.83409 & 1 & $n$ \\
\hline 4. & 25.52299 & 1 & 1 \\
\hline 5 & 29.75479 & 1 & 4 \\
\hline 6 & 32.31409 & 0 & 4 \\
\hline 7 & 35.68779 & 1 & $\eta$ \\
\hline 8 & 36.52449 & -1 & 4 \\
\hline n & 38.30060 & 1 & 16 \\
\hline 10 & 39.85089 & n & 1 \\
\hline 11 & 39.70779 & 4 & 4 \\
\hline 12 & 40.03850 & 0 & 16 \\
\hline 3 & 41.74 .779 & 1 & 1 \\
\hline 14 & 44.5 .9510 & 4 & 9 \\
\hline 15 & 46.659000 & $4+$ & 16 \\
\hline 16 & 48.47809 & ) & 25 \\
\hline 17 & $50.34+189$ & ? & 1 \\
\hline 18 & $50.9 ! 350$ & l & 75 \\
\hline 19 & 52.29059 & 't & 4 \\
\hline 0 & 54.93309 & 1 & 16 \\
\hline$?$ & 56.17450 & l & 36 \\
\hline$?$ & 56.85599 & $?$ & 7 \\
\hline 23 & 57.99109 & 4 & $? 5$ \\
\hline 24 & 58.67909 & 9 & 16 \\
\hline & 60.41139 & & \\
\hline
\end{tabular}

SINE SOJUARFi PHF: TA SINF SOUARED THFTA

DIFFER FNCE

60.41139

0.02272
0.03341
0.04264
0.04879
0.06597
0.07743
0.19390
0.04920
0.10761
0.11061
0.11534
0.11719
0.12705
0.14341
0.15693
0.16927
0.18090
0.19475
0.19417
0.21273
0.22167
0.22663
0.23497
0.21009
0.25312

0.02275
0.03932
0.04281
0.04850
0.06557
0.07746
0.09402
0.09838
0.10760
0.11068
0.11525
0.11729
0.12725
0.14370
0.15728
0.15850
0.18099
0.18506
0.19400
0.21259
0.22140
0.22651
0.23474
0.24019
0.25306

0.00047

0.00009

$-0.00017$

0.00029

0.00035

-0.0000 ?

$-0.00012$

$-0.00018$

0.00002

$-0.00008$

0.00009

$-0.000 n 9$

$-0.00030$

-

-0.00045
-0.00029

$-0.00009$

$-0.00030$

$0.00 n 17$

0.00014

0.00027

$0.00 n 12$

$0.00 n \geq 3$

.0 .00001

$0.0 n n c 6$ 


\section{THIS PAGE}

\section{WAS INTENTIONALLY \\ LEFT BLANK}




\section{APPENIIX B. EXAMPIAS OF UNSUCCESSFUL INDIXING}

'The computer output for hafnium and ice III using inadequate data are on the following pages. The 20 values used herc should be compared with those in Appendix A which produced a correct indexing for the same materials. The ice III values here are calculated directly from the ASTM card for ice III. A successful indexing could only be achicved by calculating where the reflections should be from the experimental lattice parameters and in turn using these reflections as input to INDEX. 
EXAMPLE 1. Hafnium (hexagonal)

The correct lattice parameters are $a_{o}=3.1967$ angstroms and $b_{o}=5.0578$ angstroms.

Execution time was 284 seconds.

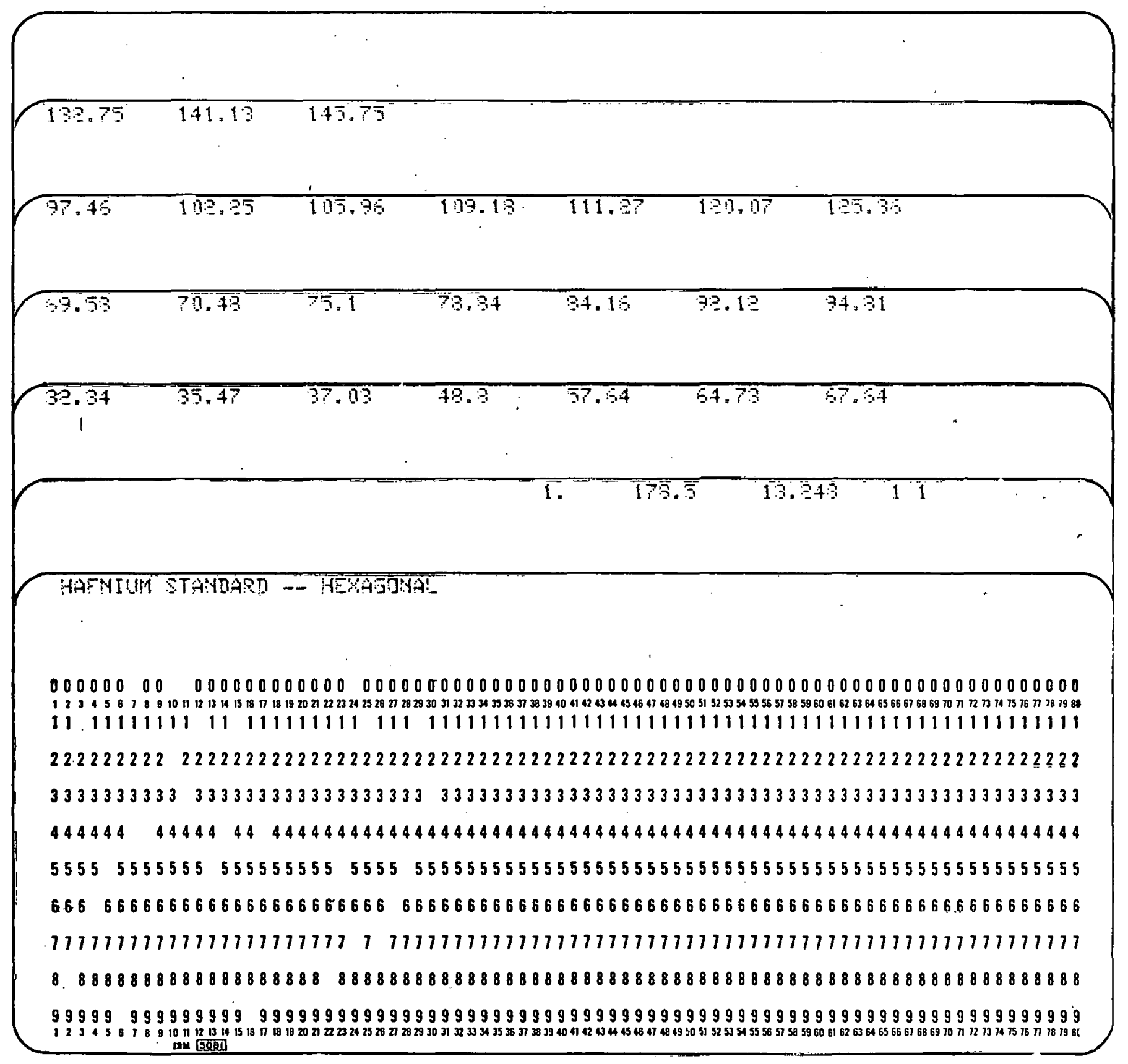


THE :OLL THING INDEXIN: IS ISN THE RASIS DF THE HEXAGONAL SYSTFN, WITH THE ERROR LESS THAN O.OOT234

THE IJVRESTLVED WAVELENGTH USFD WAS 1.54180 AND THE K-ALPHA-DNE WAVELENGTH USED WAS 1.54051

THF JENSITY IS 13.248, THE FORMULA WEIGHT IS 178.500, AND THF NUMAER IS 17.396.

THE = IRST D LINES ARE UNRF.SHLVFD. THE REST ARE K-ALPHA-I LINES.

AN ESTIMATE DF THF STANDARN DEVIATION DF SINE SQIJARED THETA IS 0.0008

AN ESTIMATE TF THE STANDARD DEVIATIIIN OF THETA IS 0.0609

AN ESTIMATE TF THE STANDARD DEVIATION OF AZFRO IS 0.1994

AN ESTIMATE DF THE STANDARD DEVIATION OF C.IERT IS 0.0847

AHAT IS 0.004846 RHAT IS $0.078 ? 98$

THE LATIICE CONSTANT AZFRT IS 12.77685 ANGSTROMS.

THE LATIICE CONSTANT CZERO IS 2.75270 ANGSTROMS.

OASERVED CALCULATFD

I TWR THFTA $\quad H H+K K+H K$ LL SINE SQUARED THETA SINE SOUARED THETA
0.00002
-0.00005
-0.00092
0.00029
-0.00021
-0.00011
-0.00034
0.00089
0.00036
0.00009
0.00026
0.00025
-0.00076
-0.00080
-0.00025
-0.00039
-0.00037
-0.00036
-0.00009
-0.00133
-0.00050
0.00032
0.00252
0.00025
DIFFFRFNCE
0.07753
0.09284
0.10176
0.17037
0.23260
0.28666
0.31013
0.32466
0.33258
0.37134
0.49296
0.44887
0.51926
0.54272
0.56517
0.50648
0.63786
0.66463
0.68147
0.75186
0.78985
0.83908
0.98677
0.91305

35.470

37.030

$57.64 C$

34.730

67.640

69.580

70.480

75.100

78.840

$84.16 ?$

9 ?. 12 ?

94.810

97.460

$10 ? .250$

105.960

109.180

111.270

125.360

132.750

141.130

145.750

16
3
21
19
48
43
64
67
4
12
67
28
91
112
52
109
67
121
76
139
163
157
183
43

0.09270

0.10084

0.17066

0.28656

0.30979

0.32555

0.37143

0.40323

0.44912

0.51850

.54193

0.63748

0.66427

0.68138

0.75053

0.83940

0.88929

0.91329 
THE FOLLOWIN- INDEXING IS ON THE BASIS OF THE HEXAGONAL SYSTEM WITH THE ERROR LESS THAN 0.003617

THE IJNRESOLVED WAVELENGTH USEO WAS 1.54180 AND THE K-ALPHA-ONE HAVELENGTH USFD WAS 1.54051 THE DENSITY IS 13.248 , THE FOPMULA WEIGHT IS 173.500 , AND THE NUMBER IS 17.396.

THE FIRST, D LINES ARE UNRESOLVED. THE REST ARE K-ALPHA-1 LINES.

AN ESTIMATE DF THE STANOARD DEVIATION TF SINE SQUARED THETA IS 0.0008

AN ESTIMATE DF THE STAMIARD DEVIATION OF THETA IS 0.0609

AN ESTIMATE OF THE STAPDARD DEVIATION OF AZERO IS 0.1994

AN ESTIMATE OF THE STANDARD DEVIATION OF CIERT IS 0.0840

AHAT IS 0.004846 RHAT IS 0.078298

THE LATTICE CONSTANT AiERO IS 12.77685 ANGSTROMS.

THE LATTICE CONSTANT CiERO IS 2.75270 ANGSTRÖMS.

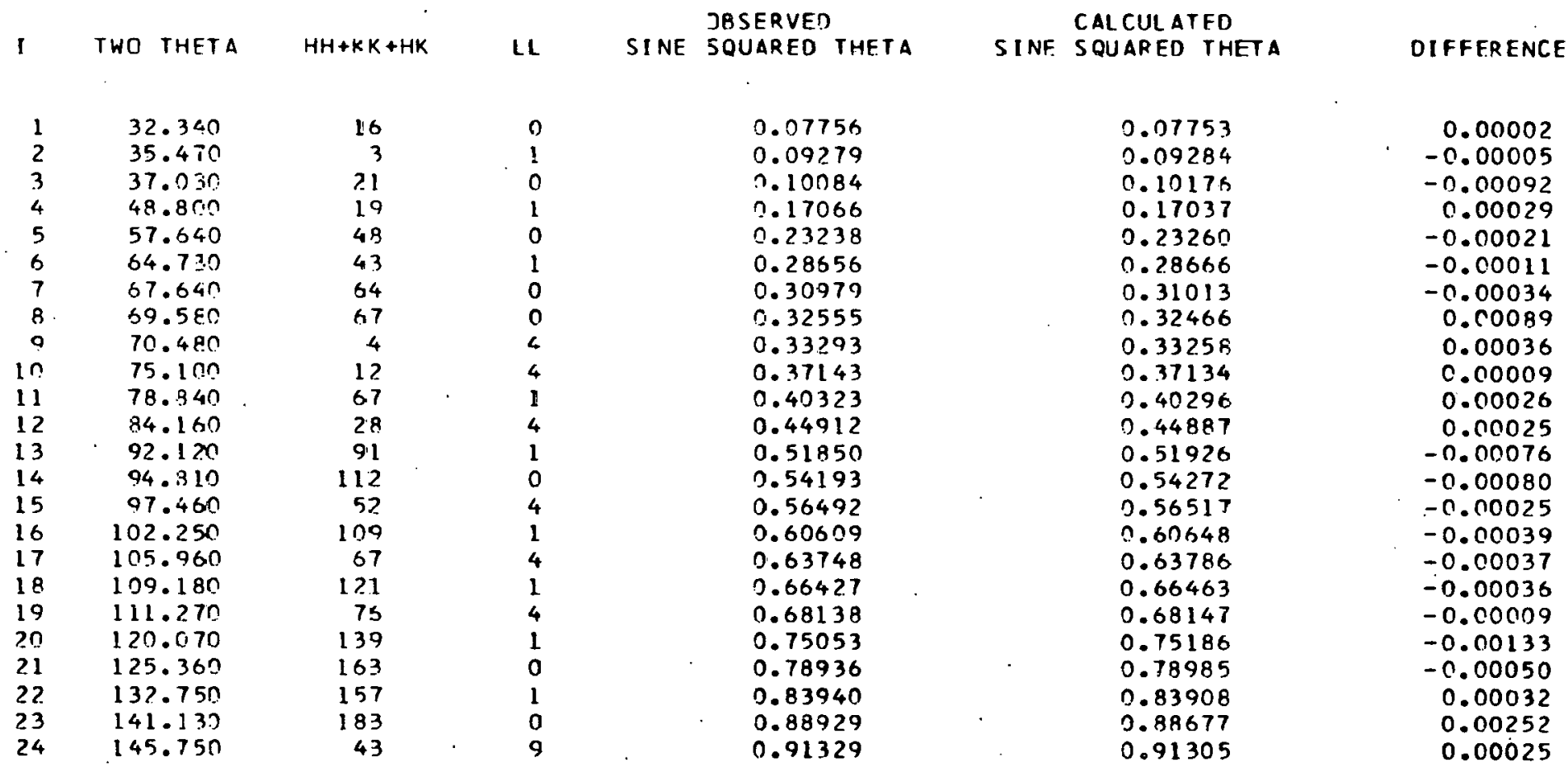


THE TOLLONING INCEXING IS DN THF BASIS OPF THE HFXAGONAL SYSTEM WITH THE ERRDP LESS THAN O. OOIBOG

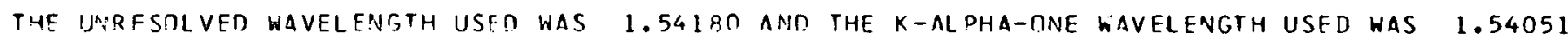

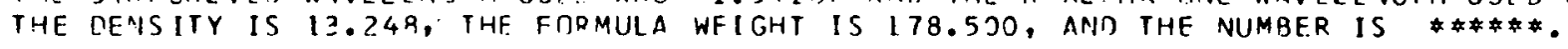

THE FIQST O LINES ARE UNRESOLVED. THE REST ARE K-ALPHA-1 LINES.

AN FSTIMATF DF THE STANDARD DEVIATION OF SINE SQUARFD THFTA IS 0.0003

AN ESTIMATE TF THE STANDART DFVIATION DF THETA IS 0.2211

AN FSTIMATE OF THE STANDAFD DEVIATION OF AZERT IS 0.1115

AN ESIIMATE DF THE STINDARD DEVIATION OF C.ZERO IS O.JS28

$A H A^{-}$IS $0.002150^{\circ}$ BHAT IS 0.008637

THE LATTICE CONSTANT AZERO IS 19.18207 ANGSTROMS.

THE IATTICE CONSTANT C.ZERT IS R.?RRI2 ANGSTROMS.

I TWO THETA HH+KK+HK LL SINE SQUARED THETA SINIF SQUARED THETA DATERERENCE

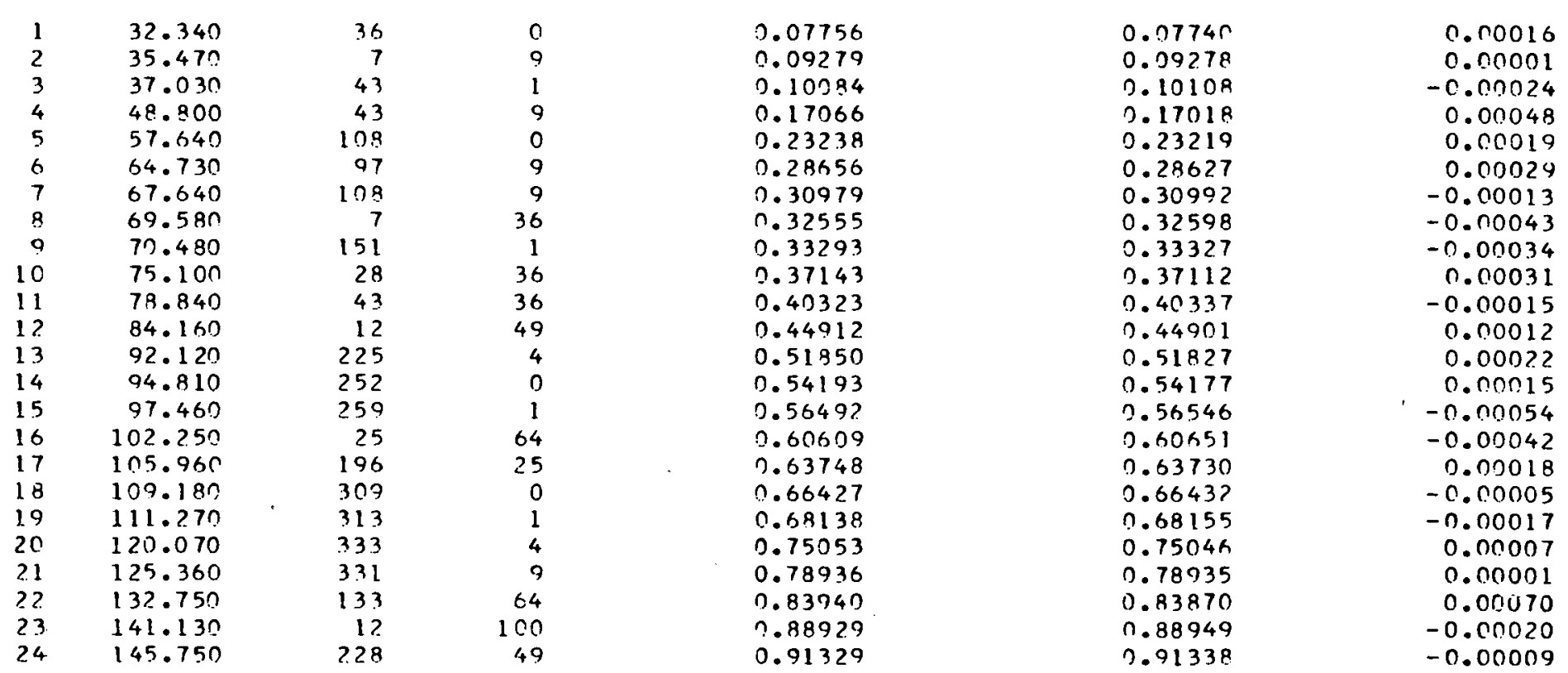


THE FOLLOWING INDEXING IS ON THE BASIS OF THE HEXAGONAL SYSTEM WITH THE ERROR LESS THAN 0.001809

THE UNRESOLVED WAVEL ENGTH USED HAS 1.54180 AND THE K-ALPHA-ONE WAVELENGTH USFD has 1.54051

THE DENSITY IS 13.248, THE FORMULA HEIGHT IS 178.500, AND THE NUMBER IS ******.

THE FIRST 0 LINES ARE UNRFSOLVED. THE REST ARE R-ALPHA-I LINES.

AN ESTIMATE DF THE STAYOARD DEVIATION OF SINE SQUARED THETA IS 0.0003

AN FSTIMATE JF THE STAVDARD DEVIATION DF THETA IS 0.0211

AN ESTIMATE DF THE STAYDARD DEVIATION OF AZERD IS 0.1115

AN ESTIMATE DF THE STANDARD DEVIATION OF CZERT IS 0.0628

AHAT IS 0.002150 B BAT IS 0.008637

THE LATTICE CONSTANT A?ERO IS 19.18207 ANGSTROMS.

THE LATTICE EONSTANT CPERO IS 8.28812 ANGSTROMS.

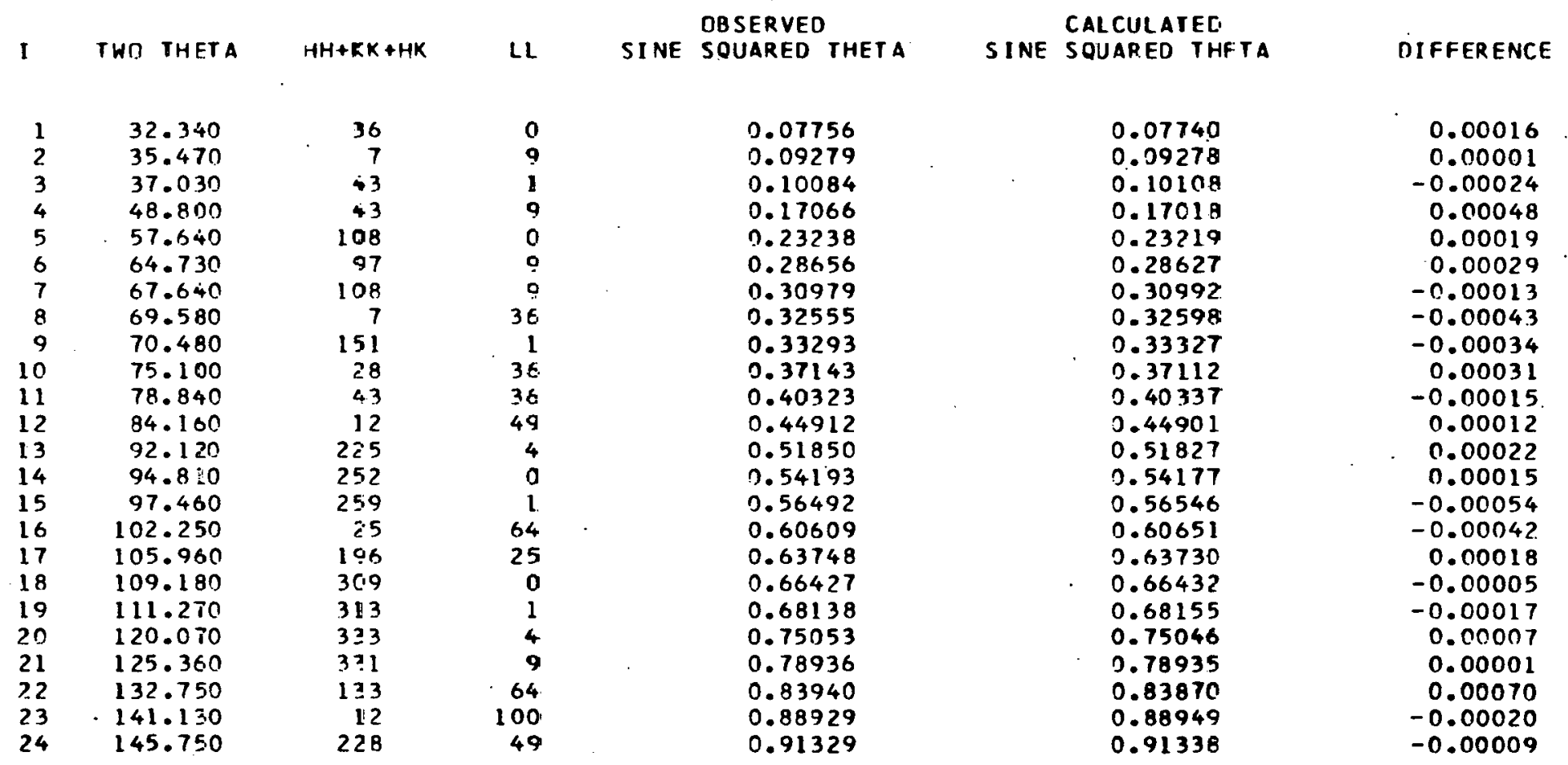


HAFNIUM STANDARD -- HEXAGONAL

THE FDLLOWING INGEXING IS ON THE BASIS OF THE HEXAGONAL SYSTEM WITH THE ERROR LESS THAN O. DOIBO9

THE UNEESOLVED WAVELENGTH USEO WAS 1.54180 AND THE K-ALPHA-ONE WAVELENGTH USED WAS 1.54051

THE DENSITY IS 13.248 , THE FORMULA WEIGHT IS 178.500 . AND THE NUMBER IS \#\#\#\#.

THE FIRST O LINES ARE UNRESOL VED. THE REST ARE K-ALPHA-1 LINES.

AN EST IMATE DF THE STANDARD DEVIATION DF SINE SQUARED THETA IS 0.0003

AN ESTIMATE TF THE SIANDARD DEVIATION OF THETA IS 0.0237

AN ESTIMATE OF THE STANDARD DEVIATION OF AZERO IS 0.1000

AN ESTIMATE DF THE STANDARD DEVIATIINN DF CZERT IS 0.1205

AHAT IS 0.002533 RHAT IS 0.009331

THE LATTICE CONSTANT AZFRO IS 17.67236 ANGSTROMS.

THE LATTICE CONSTANT CZERO IS 8.43887 ANGSTROMS.

\begin{tabular}{|c|c|c|c|c|c|c|c|c|}
\hline & & & & & NBSERVED & & CALCUL TTED & \\
\hline I & TWO THETA & $H H+K K+H K$ & $\mathrm{LL}$ & SINF & SOUARED THETA & SINF & SQUAREJ THFTA & DIFFFRENCE \\
\hline
\end{tabular}

$\begin{array}{ll}1 & 32.340 \\ 2 & 35.470 \\ 3 & 37.030 \\ 4 & 49.800 \\ 5 & 57.640 \\ 6 & 64.730 \\ 7 & 67.640 \\ 8 & 69.580 \\ 9 & 70.480 \\ 10 & 75.100 \\ 11 & 78.840 \\ 12 & 84.160 \\ 13 & 92.120 \\ 14 & 94.810 \\ 15 & 97.460 \\ 16 & 102.250 \\ 17 & 105.960 \\ 18 & 109.180 \\ 19 & 111.270 \\ 20 & 120.070 \\ 21 & 125.360 \\ 22 & 132.750 \\ 23 & 141.130 \\ 24 & 145.750\end{array}$

$\begin{array}{rrr}1 & 9 & 0.07756 \\ 7 & 9 & 0.09279 \\ 27 & 4 & 0.10084 \\ 64 & 1 & 0.17066 \\ 39 & 16 & 0.23238 \\ 100 & 4 & 0.28656 \\ 4 & 36 & 0.30979 \\ 76 & 16 & 0.32555 \\ 13 & 36 & 0.33293 \\ 117 & 9 & 0.37143 \\ 156 & 1 & 0.40323 \\ 16 & 49 & 0.44912 \\ 175 & 9 & 0.51850 \\ 201 & 4 & 0.54193 \\ 223 & 0 & 0.56492 \\ 157 & 25 & 0.60609 \\ 199 & 16 & 0.63748 \\ 259 & 1 & 0.66427 \\ 256 & 4 & 0.68138 \\ 293 & 4 & 0.75053 \\ 259 & 16 & 0.78936 \\ 121 & 64 & 0.83940 \\ 351 & 0 & 0.88929 \\ 331 & 9 & 0.91329\end{array}$

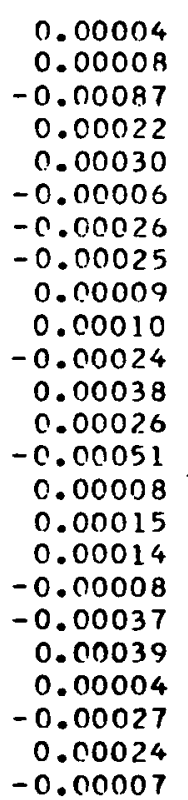


THE FOLLOWING INDEXING IS ON THE BASIS OF THE HEXAGONAL SYSTEM WITH THE ERROR LESS THAN O.OOIBO9 THE IJNRESOLVED WAVELENISTH USED WAS 1.54180 AND THE K-ALPHA-ONE WAVELENGTH USED WAS 1.54051 THE DENSITY IS 13.248 , THF FORMULA WEIGHT IS 178.500 , AND THE NUMBER IS 49.120.

$\begin{array}{llll}\text { THE FIRST D LINES ARE UNRE SOLVED. THE REST ARE K-ALPHA-I LINES. } & \\ \text { AN ESTIMATE JF THE STANDARD DEVIATION OF SINE SOUARED THETA IS } & 0.0004 \\ \text { AN ESTIMATE JF THE STANDARD DEVIATION OF THETA IS } & 0.0249 & \\ \text { AN ESTIMATE JF THE STANOARD DEVIATION DF AZERO IS } & 0.0804 & \\ \text { AN ESTIMATE JF THE STANDARD DEVIATION OF CZERT IS } & 0.0976 & \end{array}$

AN ESTIMATE JF THE STANDARD DEVIATION OF CZERT IS 0.0976

AHAT IS 0.006302 BHAT IS 0.005806

THE LATTICE CONSTANT AIERD IS 11.20364 ANGSTROMS.

THE LATTICE EONSTANT CIFRO IS 10.10840 ANGSTRDMS.

OBSERVED
I TWR THETA HH+KK+HK LL SINE SQUARED THETA SANG SQUARED THET

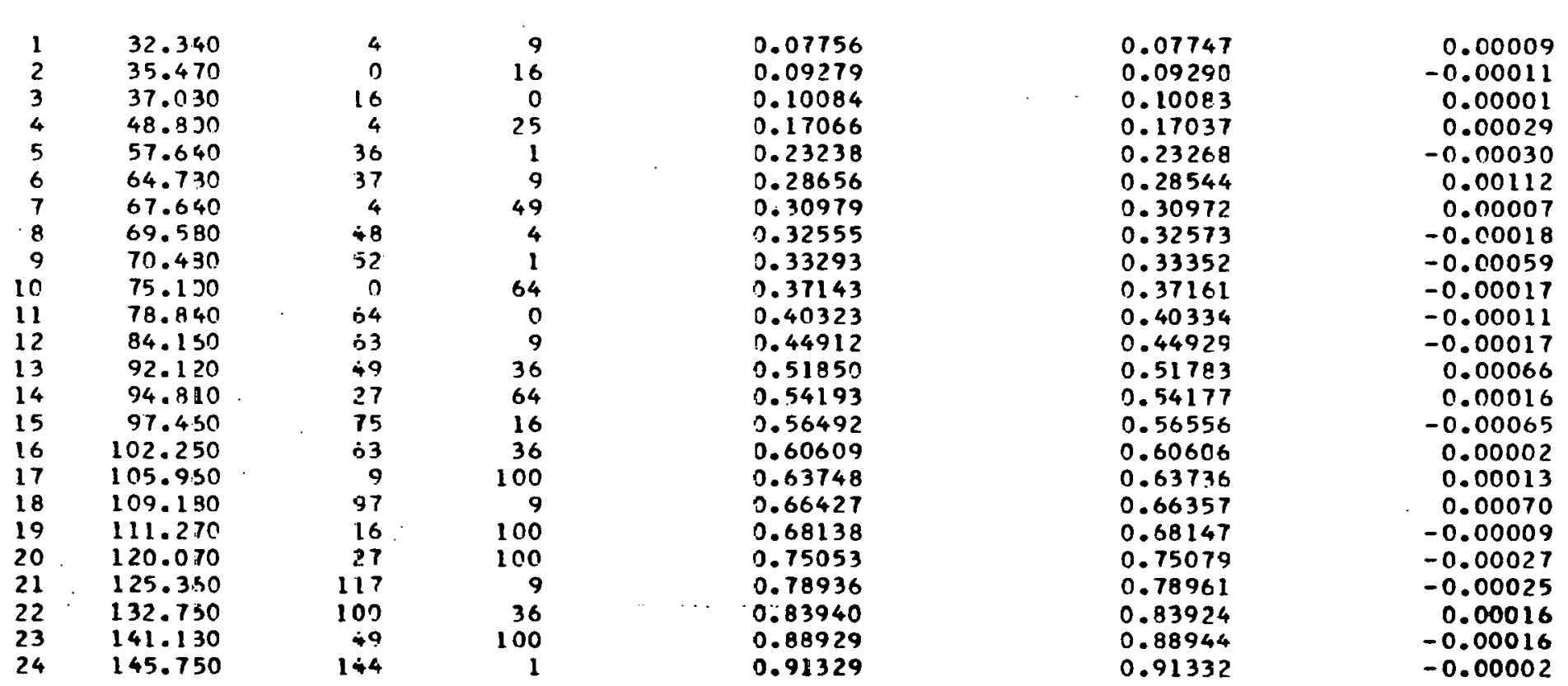


THE FOLLOWING INCEXING IS TN THE BASIS OF THE HFXAGONAL SYSTEM WITH THE ERROR LESS THAN O. OOI8O9

THF UNRESOLVED WAVELENGTH USFO WAS 1.54180 AND THE K-ALPHA-ONE WAVELENGTH USED HAS 1.54051

THE DENSITY IS 13.248 , THE FORMULA WEIGHT IS 178.500 , AND THE NUMBER IS 66.745.

THE FIRST 0 LINES ARE UNRESOLVED. THE REST ARE K-ALPHA-1 LINFS.

AN ESTIMATE OF THE STANDARD DEVIATION NF SINE SQUARED THETA IS 0.0005

AN ESTIMATE OF THF STANDARD DEVIATION OF THETA IS

AN ESTIMATE OF THE STANDARD DEVIATICN OF AZSRO IS

AN ESTIMATE OF THE STANDARD DEVIATICN OF AZSRO IS
AN ESTIMATE OF THE STANDARD DEVIATIIIN DF CZERT IS

AHAT IS . 0.005080 BHAT IS 0.004840

THE LATTICE CONSTANT AZERO IS 12.47865 ANGSTROMS.

THE LATTICE CONSTANT CZERD is 11.0.7208 ANGSTROMS.

$H H+K K+H K$

OBSERVED

CALCULATED
SINE SOUARED THETA

$1 \quad 32.340$

35.470

37.030

48.800

57.640

64.730

67.640

69.580

70.480

75.100

78.840

84.160

92.120

94.810

97.460

102.250

105.960

109.180

111.270

120.070

125.360

132.750

141.130

O

LL

SINE SOUARED THETA

DIFFERENCE

.145 .750

$$
\begin{aligned}
& 0.07756 \\
& 0.79279 \\
& 0.10084 \\
& 0.17066 \\
& 0.23238 \\
& 0.28656 \\
& 0.30979 \\
& 0.32555 \\
& 0.33293 \\
& 0.37143 \\
& 0.40323 \\
& 0.44912 \\
& 0.51850 \\
& 0.54193 \\
& 0.56492 \\
& 0.60609 \\
& 0.63748 \\
& 0.66427 \\
& 0.68138 \\
& 0.75053 \\
& 0.78936 \\
& 0.83940 \\
& 0.88929 \\
& 0.91329
\end{aligned}
$$

$$
\begin{aligned}
& 0.07743 \\
& 0.09267 \\
& 0.10064 \\
& 0.17056 \\
& 0.23152 \\
& 0.23740 \\
& 0.39974 \\
& 0.32513 \\
& 0.33312 \\
& 0.37085 \\
& 0.40256 \\
& 0.44828 \\
& 0.51901 \\
& 0.54261 \\
& 0.56524 \\
& 0.60591 \\
& 0.63793 \\
& 0.66453 \\
& 0.68157 \\
& 0.75089 \\
& 0.78892 \\
& 0.83915 \\
& 0.88902 \\
& 0.91349
\end{aligned}
$$

$$
\begin{array}{r}
0.00012 \\
0.00012 \\
0.00020 \\
0.00010 \\
0.00086 \\
-0.00084 \\
0.00005 \\
0.00042 \\
-0.00019 \\
0.00059 \\
0.00066 \\
0.00084 \\
-0.00051 \\
-0.00068 \\
-0.00033 \\
0.00018 \\
-0.00045 \\
-0.00026 \\
-0.00019 \\
-0.00036 \\
0.00044 \\
0.00025 \\
0.00027 \\
-0.00019
\end{array}
$$


THE FOLL DWING INDEXING IS DN THE BASIS DF THE HEXAGONAL SYSTEM WITH THE ERRMR LESS THAN O. OOIBO9

THE UNRESOLVED WAVELFNiTH USED HAS 1.54180 AND THE K-ALPHA-ONE WAVELENGTH USED WAS 1.54051

THE DENSITY IS 13.248 , THE FORMULA WEIGHT IS 178.500. ANI THE NUMAER IS 88.015 .

THE FIRST O LINES ARE UNRFSOLVED. THE REST ARE K-ALPHA-1 LINES.

AN ESTIMATE DF THF STANDARD DEVIATINN DF SINE SOUARED THETA IS 0.0004

AN FSTIMATE DF THE STANDARD DEVIATIDN DF THETA IS 0.0261

AN ESTIMATE JF THE STANDARD DFVIATIDN OF AZFRO IS 0.1467

AN ESTIMATE TF THE STANDARD DEVIATINN OF CZERD IS 0.3961

AHAT IS 0.003853 BHAT IS 0.004837

THE LATTICE CONSTANT A?ERT IS 14.37806 ANGSTROMS.

THF LATTICE CONSTANT CZERT IS 11.07453 ANGSTROMS.

I THO THETA HH+FK+HK LL SINE SQUARED THETA S SINE SOUARED THETALATED

SINF SQUARED THETA DIFFERENCE

$$
\begin{aligned}
& 32.340 \\
& 35.470 \\
& 37.030 \\
& 48.800 \\
& 57.640 \\
& 64.730 \\
& 67.640 \\
& 69.580 \\
& 70.480 \\
& 75.100 \\
& 73.840 \\
& 84.160 \\
& 92.120 \\
& 94.810 \\
& 97.460 \\
& 102.250 \\
& 105.960 \\
& 109.180 \\
& 111.270 \\
& 120.070 \\
& 125.360 \\
& 132.750 \\
& 141.130
\end{aligned}
$$

$H H+H K+H K$

0.07756
0.09779
0.10984
0.17966
0.23238
0.28656
0.30979
0.32555
0.33293
0.37143
0.40323
0.44912
0.51850
0.54193
0.56492
0.60609
0.63748
0.66427
0.68138
0.75053
0.78936
0.83940
0.88729
0.91329


THE FOLLOWING INDEXING IS DN THE BASIS DF THE HEXAGONAL SYSTEM WITH THE ERPDR LESS THAN O.OOIBO9

THE UNRESTLVED WAVELFNGTH USEO WAS $\therefore 54180$ AND THE K-AL OHA-ONE WAVELENGTH USED WAS 1.54051

THE DEYSITY IS 13.248, THE FDRMULA WEIGHT IS $178.50 ?$, AND THE NUMRER IS 68.082 .

THE FIPST O LINES ARF IJNRFSOLVFD. THE REST AP.E K-ALPHA-1 I INES.

AN ESTIMATE DF THE STANDAR? DEVIATION OF SINF SQUARFD THFTA IS 0.0007

AN ESTIMATE TF THE STINIARN DEVIATINW OF THFTA IS 0.0477

AN ESTIMATE DF THE STINNARD DEVIATIDH DF AZERD IS 0.1710

AN ESTIMATE OF THE STGNIAARD DFVIATION OF CZERO IS C.2.2OI

AHAT IS 0.005114 BHAT IS 0.004590

THF. LATIICF CONSTAVT AZERO IS 12.43698 ANGSTRTMS.

THE LATIICE CONSTAVT CZERO IS 11.35970 ANSSTRTMS.

I TWO THETA HH+KK+HK LL SINF SQUARFD THFTA SINE SOIJAPED THF

$\begin{array}{ll}1 & 32.340 \\ 2 & 35.470 \\ 3 & 37.030 \\ 4 & 48.800 \\ 5 & 57.640 \\ 6 & 64.730 \\ 7 & 67.640 \\ 8 & 69.580 \\ 9 & 70.480 \\ 10 & 75.100 \\ 11 & 78.840 \\ 12 & 84.160 \\ 13 & 92.120 \\ 14 & 94.810 \\ 15 & 97.460 \\ 16 & 102.250 \\ 17 & 105.960 \\ 18 & 109.180 \\ 19 & 111.270 \\ 20 & 120.070 \\ 21 & 125.360 \\ 22 & 132.750 \\ 23 & 141.130 \\ 24 & 145.750\end{array}$

$\begin{array}{rl}9 & 0.07756 \\ 16 & 0.09279 \\ 4 & 0.10084 \\ 16 & 0.17066 \\ 16 & 0.23238 \\ 9 & 0.28656 \\ 4 & 0.30979 \\ 1 & 0.32555 \\ 9 & 0.33293 \\ 81 & 0.37143 \\ 0 & 0.40323 \\ 4 & 0.44912 \\ 25 & 0.51950 \\ 100 & 0.54193 \\ 100 & 0.56492 \\ 64 & 0.60609 \\ 81 & 0.53748 \\ 1 & 0.66427 \\ 144 & 0.68138 \\ 100 & 0.75053 \\ 64 & 0.73936 \\ 9 & 0.83940 \\ 100 & 0.83929 \\ 4 & 0.91329\end{array}$

0.07711
0.09389
0.10919
0.17060
0.23197
0.28679
0.30987
0.32678
0.33282
0.37175
0.40402
0.44795
0.51876
0.54078
0.56635
0.60576
0.63769
0.66432
0.63135
0.75047
0.73981
0.83912
0.88855
0.91334

DIFFFRENCE

0.00045

$-0.00110$

0.00065

0.00005

0.00041

$-0.00023$

$-0.00008$

$-0.00123$

0.00012

- r. .00032

$-0.00050$

0.00117

$-0.00026$

0.00114

$-0.00144$

0.00039

$-0.00021$

$-0.00005$

0.00003

0.00006 .

$-0.00045$

$0.0002 B$

0.00074

84
175

0.91329

$-0.00005$ 


\section{EXAMPLE 2. Ice III}

The correct lattice parameters are supposed to be $a_{0}=10.20$ angstroms, $b_{0}=5.87$ angstroms, and $c_{o}=7.17$ angstroms. Execution time was 311 seconds.

\subsection{9}

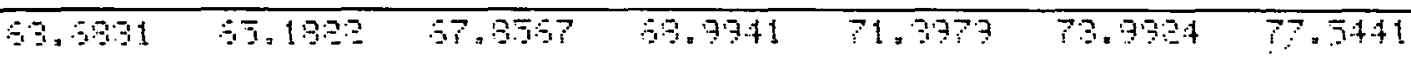

49.927

50.974 .3

54,573

96.7794

59,753

31.455

58.799

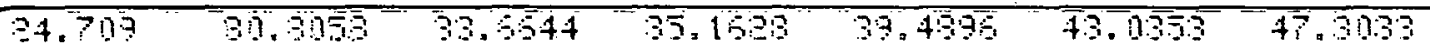

1.

$1 ;$

1.

11

I:E III

00000000000000000000000000000000000000000000000000000000000000000000000000000000

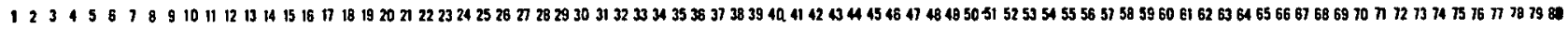
111111111111111111111111111111111111111111111111111111111111111111111111111111

22222222222222222222222222222222222222222222222222222222222222222222232332222222

$3 \quad 333333333333333333333333333333333333333333333333333333333333333333333333333333$ 44444444444444444444444444444444444444444444444444444444444444444444444444444444 5555555555555555555555555555555555555555555555555555555555555555555555555555555 66666666666666666666666666666666666666666666666666666666666666666666666666666666  8888888888888888888888888888888888888888888888888888888888888888888888888888888888 999 9999999999999999999999999999999999999999999999999999999999999999999999999

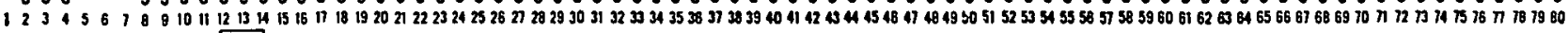
13x [09] 
ICE III

THE FILLOWING INDEXING IS TN THF BASIS TF THF ORTHORHDMBIC SYSTEM WITH THE FRPOR LESS THAN

THE LATTICE CONSTANT AZERO IS 3.93607 ANSSTRMMS.

THE LATTICE CONSTANT RTFRE IS 7.90371 ANGSTROMS.

THE LATTICE CONSTANT C.IFRO IS 2.70246 ANGSTRMMS.

THE IJNRFSDLVFD WAVELENGTH USFN WAS $1.5 \$ 180$ AND THE K-ALPHA-ONF WAVFLENGTH USFD WAS 1.54051 THE DEVSITY IS 1.000 THE FIRMULA WFIGHT IS 18.000 , AND THE NUMBER IS 1.03 .

THE FI SST O LIVFS ARE UVRFSTLVED. THE RFST AP.E K-ALPHA-1 LINES.

AN FSTIYATE RF THE STANDARD DEVIATION DF THFIA IS 0.35895

AN. FST IMATE DF THE STANDARD DEVIATION DF SIVE SQUARED THETA IS 0.01252

AN ESTIMATE DF THF STANDARD TEVIATION DF AZERO IS 0.03990

AN ESTIMATE NF THE STANMARD DEVIATINN OF RZERO IS 0.03147

AV SSTIMATE OF THE STANMARD DFVIATIDN RF CIERD IS 0.04396
TBSFR VED
CAECULATFD

TWN THETA

$H H \quad K K \quad L L$

$\begin{array}{ll}1 & 24.70900 \\ 2 & 30.80579 \\ 3 & 33.66440 \\ 4 & 35.16280 \\ 5 & 39.48959 \\ 6 & 43.03529 \\ 7 & 47.30330 \\ 8 & 48.92729 \\ 9 & 50.97449 \\ 10 & 54.57880 \\ 11 & 56.77939 \\ 12 & 58.35320 \\ 13 & 60.45499 \\ 14 & 62.72389 \\ 15 & 63.68309 \\ 16 & 65.18219 \\ 17 & 57.85669 \\ 18 & 68.99409 \\ 19 & 71.39789 \\ ? 0 & 73.99239 \\ 21 & 77.54410 \\ 22 & 79.86420\end{array}$

$\begin{array}{lll}1 & 0 & 0 \\ 0 & 1 & 0 \\ 0 & 0 & 1 \\ 0 & 1 & 0 \\ 1 & 1 & 0 \\ 1 & 0 & 1 \\ 0 & 1 & 1 \\ 4 & 0 & 0 \\ 1 & 1 & 1 \\ 4 & 1 & 0 \\ 4 & 0 & 1 \\ 4 & 1 & 0 \\ 4 & 0 & 1 \\ 7 & 4 & 0 \\ 4 & 1 & 1 \\ 0 & 4 & 0 \\ 4 & 1 & 1 \\ 1 & 4 & 0 \\ 9 & 0 & 0 \\ 0 & 4 & 1 \\ 0 & 1 & 4 \\ 9 & 1 & 0\end{array}$

SINF SQUARED THETA

SINE SQUARED THETA

CIFFER FNCE

EXFCUTEON TIME

28.27 SEC.

0.03830

0.07037

0.08124

0.07037

1. 10866

ก.11953

D. 15160

0.15318

0.18990

D. 22355

$? .23442$

2. 22355

0.23442

0.28146

0. 30478

0.28146

0.30478

0.31976

C. 34466

0.36270

0.39531

0.41502 
ICE III

THE FOLLOWING INDEXING IS ON THE
THE LATTICE CONSTANT A?ERO IS THE LATTICE CONSTANT RIERO IS

THF LATTICE EONSTANT C,?ERO IS

BASIS DF THE ORTHORH
3.58882 ANGSTROMS.
7.42102 ANGSTROMS.
2.88835 ANGSTROMS.

2.88835 ANGSTROMS.

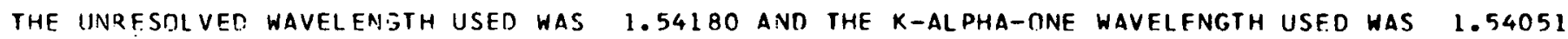
THE DEVSITY IS 1.000 THE FRRMULA. WEIGHT IS 18.000, AND THE NUMBER IS 2.5.

THE FIRST ? LINES ARE UNRESDLVEO. THE REST ARE K-ALPHA-1 LINES.

AN FSTIMATE TF THE STANDARD DFVIATION OF THETA IS 0.283 .3

AN ESTIMATE ITF THF STANDARD DEVIATION DF SINF SQUARED THETA IS 0.00412

AN ESTIMATE DIF THE STAPIDARD DEVIATINN: OF ATERO IS 0.01240

AN SSTIMATF DF THE STANDARO DEVIATION OF RZERO IS 0.03342

AN ESTIMATF NF THE STANDARD DEVIATIDN OF CZFRD IS 0.01128
TWO THETA HH RK LL SINE SQUARED THETA
CALCULATED

$\begin{array}{ll}1 & 24.70900 \\ 2 & 30.80579 \\ 3 & 37.66440 \\ 4 & 35.16280 \\ 5 & 39.48959 \\ 6 & 43.03529 \\ 7 & 47.30330 \\ 8 & 48.92729 \\ 9 & 50.97449 \\ 10 & 54.57880 \\ 11 & 56.77939 \\ 12 & 58.35320 \\ 13 & 60.45499 \\ 14 & 62.72389 \\ 15 & 63.68309 \\ 16 & 65.18219 \\ 17 & 67.85669 \\ 18 & 68.99409 \\ 19 & 71.39799 \\ 20 & 73.99239 \\ 21 & 77.54410 \\ 22 & 79.86420\end{array}$

$\begin{array}{rrr}1 & 0 & 0 \\ 0 & 0 & 1 \\ 0 & 1 & 1 \\ 1 & 4 & 0 \\ 1 & 0 & 1 \\ 1 & 1 & 1 \\ 1 & 4 & 1 \\ 0 & 0 & 1 \\ 4 & 0 & 0 \\ 1 & 9 & 1 \\ 4 & 4 & 0 \\ 0 & 16 & 1 \\ 4 & 0 & 1 \\ 4 & 1 & 1 \\ 4 & 9 & 0 \\ 0 & 0 & 4 \\ 1 & 25 & 0 \\ 0 & 4 & 4 \\ 1 & 1 & 4 \\ 4 & 16 & 0 \\ 1 & 25 & 1 \\ 9 & 0 & 0\end{array}$

$$
\begin{aligned}
& 0.04578 \\
& 0.07055 \\
& 0.08385 \\
& 0.09124 \\
& 0.11413 \\
& 0.13453 \\
& 0.16094 \\
& 0.17149 \\
& 0.18517 \\
& 0.21021 \\
& 0.22607 \\
& 0.23766 \\
& 0.25345 \\
& 0.27086 \\
& 0.27833 \\
& 0.29013 \\
& 0.31154 \\
& 0.32077 \\
& 0.34050 \\
& 0.36212 \\
& 0.39216 \\
& 0.41201
\end{aligned}
$$

0.07112

0.08199

0.11718

0.12795

0.16027

0.16807

0.18426

0.21414

0.22735

0.24349

0.25537

0. 26615

c. 28122

0.28446

0. 31539

0.32756

0. 34130

0.35663

0.38651
0.41458

\section{DIFFER ENCE}

$$
\begin{array}{r}
-0.00029 \\
-0.00057 \\
0.00196 \\
0.00208 \\
-0.00305 \\
0.00658 \\
0.00067 \\
0.00342 \\
0.00091 \\
-0.00393 \\
-0.00128 \\
-0.00583 \\
-0.00193 \\
0.00471 \\
-0.00289 \\
0.00567 \\
-0.00365 \\
-0.00679 \\
-0.00080 \\
0.00549 \\
0.00565 \\
-0.00257
\end{array}
$$


IC.E III

THF FOLLOWING INDEXING IS TN THE

THE LATTICE CONSTANT ALFRO IS

THF T.ATTICE CONSTAVT R?ERT IS

BASIS DF THE ORTH()RH
3.58382 ANGSTROMS:
$7.4210 ?$ ANGSTROMS.

THE LATTICF CONSTANT CIFRO IS 2.88335 ANGSTROMS.

THF IJVRESILVEO WAVELFNGTH USFO WAS 1.54180 AND THE K-ALPHA-ONE WAVFLFNGTH USFD WAS 1.54051 THE DENSITY IS l.ODO THF FlIPMULA WE I.TH IS 18.000, AND THE NIJMBF. IS 2.57 .

THF FIQST 0 LINFS ADE UNRF SCLVED. THE REST ARE K-NLPHA-I LINES.

AN FSTIMATE RF THE STANDARO DFVIATION DF THETA IS 0.28325

AV ESTIYATE DF THE STAVIAR? DEVIATION MF SINF SOUAREN THETA IS 0.00412

AN ESTIMATE DF THE STANDARO DEVIATION OF AZFRO IS 0.01240

AN ESTIMATE DF THE STAVDARD DEVIATIDN OF RZERD IS 0.03342

AN CSTIMATE DF THF STANDAPN OFVIATION OF CIERO IS 0.01128

TRSERVFD CALCULATED

\begin{tabular}{|c|c|c|c|c|c|c|c|}
\hline 1 & 24.70900 & 1 & 0 & 0 & 0.04578 & 0.04606 & -0.00029 \\
\hline 2 & 38.80579 & 0 & $n$ & 1 & 0.07055 & 0.07112 & -0.00057 \\
\hline 3 & 33.65440 & ? & 1 & 1 & 0.08385 & 0.08189 & 0.00196 \\
\hline 4 & 35.16280 & 1 & 4 & 0 & 0.09124 & 0.08916 & 0.00208 \\
\hline 5 & 39.48959 & 1 & 0 & 1 & 0.11413 & 0.11718 & -0.00305 \\
\hline 6 & 43.03529 & 1 & 1 & 1 & 0.13453 & 0.12795 & 0.00658 \\
\hline 7 & 47.30330 & 1 & 4 & 1 & 0.16094 & 0.16027 & $0.0006 \mathrm{~J}$ \\
\hline$R$ & 48.92729 & o & 9 & 1 & 0.17149 & 0.16897 & $0.0034 ?$ \\
\hline 9 & 50.97449 & 4 & $n$ & $n$ & 0.18517 & 0.18426 & 0.00091 \\
\hline $1^{n}$ & 54.57880 & 1 & 9 & 1 & 0.21021 & 0.21414 & -0.00303 \\
\hline 11 & 56.77939 & 4 & 4 & 0 & 0.22507 & 0.22735 & -0.00128 \\
\hline $1 ?$ & 58.35370 & 0 & 16 & 1 & 0.23766 & 0.24349 & -0.00583 \\
\hline 13 & 60.45499 & 4 & 0 & 1 & 0.25345 & 0.25537 & -0.00193 \\
\hline 14 & 52.72399 & 4 & 1 & l & 0.27086 & 0.26615 & 0.00471 \\
\hline 15 & 63.68309 & 4 & 9 & 0 & 0.27833 & 0.28122 & -0.00289 \\
\hline 16 & 65.182 .19 & n & 0 & 4 & 0.29013 & 0.28446 & 0.00567 \\
\hline 17 & 57.85669 & 1 & 2.5 & 0 & 0.31154 & 0.31539 & -0.00385 \\
\hline $1 a$ & 58.99409 & 0 & 4 & 4 & 0.32077 & 0.32756 & -0.00679 \\
\hline 19 & 71.39789 & 1 & i & 4 & 0.34050 & 0.34130 & -0.00080 \\
\hline$? 0$ & 73.99239 & 4 & 16 & 0 & 0.36212 & 0.35663 & 0.00549 \\
\hline 21 & 77.54410 & 1 & 25 & 1 & 0.39216 & 0.38651 & 0.00565 \\
\hline 22 & 79.8642 .0 & 9 & 0 & 0 & 0.41201 & 0.41458 & -0.00257 \\
\hline
\end{tabular}

EXECUTION TIME 35.38 SEC. 
ICE II I

THE FOLLOW ING INDFXING IS ON THE

THE LATTICE CONSTANT BZFRO IS

BASIS DF THE CRTHOR
6.39762 ANGSTROMS
4.46583 ANG STROMS

THF LATTICE CONSTANT CZFRO IS 3.35988 ANGSTROMS.

THE UNRESOLVED WAVELENGTH USED WAS 1.54180 AND THE K-ALPHA-ONE WAVELENGTH USED WAS 1.54051

THE DENSITY IS 1.000 THE FORMULA WEIGHT IS IB.000, AND THE. NUMBER IS 3.21.

THE FIRST O LINES ARE UNRESOLVFD. THE REST ARE K-ALPHA-1 LINES.

AN ESTIMATE DF THE STANDARD DEVIATION OF THETA IS 0.21065

AN ESTIMATE OF THE STANDARI DEVIATION OF SINE SQUARED THETA IS

AN ESTIMATE DF THE STANDARD DEVIATION OF AZERO IS 0.01174

AN ESTIMATE OF THE STANDARD DEVIATION OF BZFRD IS 0.01211

AN ESTIMATE DF THE STANDARO DEVIATION OF CZFRO IS 0.01046

I TWO THETA HH KK LBSERVED. CALCULATEO

I TWO THETA HH KK LL SINE SQUARED THETA SINE SQUARED THFT

DIFFERENCE

$\begin{array}{lrlll}24.70900 & 1 & 1 & 0 & 0.04578 \\ 30.80579 & 1 & 0 & 1 & 0.07055 \\ 33.66440 & 0 & 1 & 1 & 0.08385 \\ 35.16780 & 4 & 1 & 0 & 0.09124 \\ 39.48959 & 4 & 0 & 1 & 0.11413 \\ 43.03579 & 1 & 4 & 0 & 0.13453 \\ 47.30330 & 9 & 1 & 0 & 0.16094 \\ 48.92729 & 0 & 4 & 1 & 0.17149 \\ 50.97449 & 9 & 0 & 1 & 0.18517 \\ 54.57880 & 9 & 1 & 1 & 0.21021 \\ 56.77939 & 1 & 0 & 4 & 0.22607 \\ 58.35320 & 0 & 1 & 4 & 0.23766 \\ 60.45499 & 1 & 1 & 4 & 0.25345 \\ 62.72389 & 0 & 9 & 0 & 0.27086 \\ 63.68309 & 1 & 9 & 0 & 0.27833 \\ 65.18219 & 16 & 0 & 1 & 0.29013 \\ 67.85659 & 16 & 1 & 1 & 0.31154 \\ 68.99409 & 0 & 9 & 1 & 0.32077 \\ 71.39789 & 9 & 0 & 4 & 0.34050 \\ 73.99239 & 25 & 0 & 0 & 0.36212 \\ 77.54410 & 25 & 1 & 0 & 0.39216 \\ 79.86420 & 25 & 0 & 1 & 0.41201\end{array}$

0.04424
0.06705
0.08230
0.08773
0.11054
0.13349
0.16021
0.17155
0.18301
0.21276
0.22472
0.23997
0.25447
0.26774
0.28223
0.28448
0.3142 .3
0.32029
0.34068
0.36239
0.39213
0.41494

0.00153

0.00349

0.00351

0.00351

0.00104

0.00104
0.00073

$-0.00006$

0.00215

$-0.00255$

0.00135

$-0.00231$

$-0.00102$

0.00312

$-0.00390$

0.00565

$-0.00269$

$0.0004 \mathrm{~B}$

$-0.00018$

$-0.00027$

0.00002

$-0.00293$

EXECUTION TIMF 39.70 SEC. 
ICE III

THE FOLLOWING INDEXING IS ON THE BASIS OF THE ORTHORHOMBIC SYSTEM WITH THE FRROR LESS THAN O.OO3G58

THE LATTICE CONSTANT AZFRM IS 17.93768 ANGSTROMS.

THE LATTICE CONSTANT B?ERC IS 2.89716 ANGSTRCMS.

THE IJNRESOLVED WAVELENGTH USED WAS 1.54180 AND THE K-ALPHA-ONF WAVELENGTH USEO WAS 1.54051

THE DENSITY IS 1. IOก THE FRRMULA WEIGHT IS 18.000 . AND THE NUMBFR IS $: 2.34$.

THE FIRST O LINES ARF UNRESOLVFD. THE P.EST ARE K-ALPHA-1 LINFS.

AN ESTIMATE DF THE STANDAR? DEVIATION RF THETA IS 0.05451

AN ESTIMATE DF THE SIANDARD DFVIATION OF SINE SQUARED THETA IS 0.00671

AN ESTIMATE DF THE STANDARD DEVIATION DF AZERO IS 0.01103

AN ESTIMATE TF THF STAMTARD DFVIATION OF BZERT IS 0.00200

AN ESTIMATE DF THE STANDARJ DEVIATION DF CZERO IS 0.00477

I THI THETA HH KK LL SINE SOUARED THETA SINE SOUARED THET

SINE SQUARED THETA SINE SQUARED THETA DIFFERENEE

$\begin{array}{rrrr}24.70900 & 0 & 0 & 4 \\ 30.80579 & 0 & 1 & 0 \\ 33.66440 & 1 & 1 & 1 \\ 35.16280 & 49 & 0 & 0 \\ 39.43959 & 36 & 0 & 4 \\ 43.03529 & 16 & 0 & 9 \\ 47.30330 & 49 & 1 & 0 \\ 48.92729 & 36 & 0 & 9 \\ 50.97449 & 0 & 0 & 16 \\ 54.57980 & 49 & 1 & 4 \\ 56.77939 & 121 & 0 & 0 \\ 58.35320 & 121 & 0 & 1 \\ 60.45499 & 36 & 0 & 16 \\ 62.72389 & 121 & 0 & 4 \\ 63.68309 & 49 & 0 & 16 \\ 65.18219 & 4 & 4 & 0 \\ 67.85669 & 9 & 4 & 1 \\ 68.99409 & 16 & 0 & 25 \\ 71.39789 & 25 & 4 & 1 \\ 73.99239 & 100 & 1 & 9 \\ 77.54410 & 16 & 1 & 25 \\ 79.86420 & 196 & 0 & 4\end{array}$

0.04578
0.07055
0.08395
0.09124
0.11413
0.13453
0.16094
0.17149
0.18517
0.21021
0.22607
0.23766
0.25345
0.27086
0.27833
0.29013
0.31154
0.32077
0.34050
0.36212
0.39216
0.41201

0.04657

0.07058

0.08419

0.09137

0.11370

0.13462

0.16205

0.17191

0.18629

0.20862

0.22562

0.23776

0.25342

0.27719

0.27766

0.20020

0.31116

0.32071

0.34100

0.36194

0.39160

0.41204

EXECUTION TIMF $50.80 \mathrm{SEC}$. 
IC.E III

THE FDLLOWING INDEXING IS ON THF BASIS OF THE ORTHORHOMBIC SYSTEM WITH THE ERROR LFSS THAN O.OOI829 THE LATTICE CONSTANT A?ERO IS 17.80865 ANGSTROMS. .

THE LATTICE CONSTANT B?ERO IS 7.14896 ANGSTROMS.

THE LATTICE CONSTANT CZERO IS 5.80120 ANGSTROMS.

THE UNRESחLVED WAVELEN JTH USED WAS 1.54180 AND. THE K-ALPHA-ONE WAVELENGTH USED WAS 1.54051

THE DENSITY IS 1.JOO THE FORMULA. WE IGHT IS 18.000 , AND THE NUMBER IS 24.71 .

THE FIRST D LINES AR E UNRESOLVED. THE REST ARE K-ALPHA-I LINES.

AN ESTIMATE DF THE STANDARD DEVIATION OF THETA IS

AN ESTIMATE JF THE STANDARD DEVIATION DF SINE SQUARED THETA IS 0.00037

AN ESTIMATE DF THE STANDARO DEVIATION OF AZERO IS 0.01006

AN SSTIMATE JF THE STANDARD DEVIAEION OF BIER! IS 0.00293

AN ESTIMATF DF THE STANDARD DEVIATION OF CZERD IS 0.00210

I TWD THETA OBSERVED CALCULATED

I TWO THETA HH LK LL SINE SQUARED THETA SINE SQUARED THETA DIFFERENCE

$\begin{array}{rrrrrrr}24.70900 & .0 & 4 & 0 & 0.04578 & 0.04643 & -0.00056 \\ 30.30579 & 0 & 0 & 4 & 0.07055 & 0.07052 & 0.00003 \\ 33.66440 & 1 & 1 & 4 & 0.08385 & 0.08400 & -0.00015 \\ 35.16280 & 49 & 0 & 0 & 0.09124 & 0.09166 & -0.00042 \\ 39.48959 & 36 & 4 & 0 & 0.11413 & 0.11378 & 0.00035 \\ 43.03529 & 16 & 9 & 0 & 0.13453 & 0.13441 & 0.00012 \\ 47.30330 & 1 & 0 & 9 & 0.16094 & 0.16053 & 0.00041 \\ 48.92729 & 36 & 9 & 0 & 0.17149 & 0.17182 & -0.00033 \\ 50.97449 & 0 & 16 & 0 & 0.18517 & 0.18574 & -0.00057 \\ 54.57880 & 4 & 16 & 1 & 0.21021 & 0.21085 & -0.00064 \\ 56.77939 & 36 & 0 & 9 & 0.22607 & 0.22601 & 0.00006 \\ 58.35320 & 36 & 1 & 9 & 0.23766 & 0.23762 & 0.00004 \\ 60.45499 & 36 & 16 & 0 & 0.25345 & 0.25308 & 0.00036 \\ 62.72389 & 4 & 9 & 9 & 0.27086 & 0.27062 & 0.00024 \\ 63.68309 & 64 & 0 & 9 & 0.27833 & 0.27839 & -0.00006 \\ 65.18219 & 64 & 1 & 9 & 0.29013 & 0.312000 & 0.00014 \\ 67.85569 & 16 & 0 & 16 & 0.31154 & 0.32015 & -0.00046 \\ 68.99409 & 16 & 25 & 0 & 0.32077 & 0.34044 & 0.00062 \\ 71.39789 & 25 & 1 & 16 & 0.34050 & 0.36207 & 0.00006 \\ 73.99239 & 100 & 9 & 4 & 0.36212 & 0.39217 & 0.00005 \\ 77.54410 & 100- & 4 & 9 & 0.39216 & 0.41209 & -0.00001 \\ 79.86420 & 121 & 16 & 0 & 0.41201 & & -0.00009\end{array}$

EXERUTION TIME 96.06 SEC. 
ICE III

THE FOILOWING INCEXING, IS ON THE BASIS DF THE ORTHORHOMBIC SYSTEM WITH THE FRROR LESS THAN O.OOBG5B

THE LATTICE CONSTANT AZFR IS 17.33768 ANGSTROMS.

THE LATTICE CONSTANT BIERO IS 2.89716 ANGSTRCMS.

THE LATTICE CINSTANT CZFRO IS T.13838 ANGSTROMS.

THE IJNRESOLVED WAVELENGTH USED WAS 1.54180 AND THE K-ALPHA-ONF WAVELENGTH USED WAS I.5405I THE DENSITY IS 1. NDS THE FRRMULA WEIGHT IS 18.000. AND THE NUMBER IS 12.34 .

THE FIRST O LINES ARF UNRESDLVFD. THE REST ARE K-ALPHA-1 LINFS.

AN ESTIMATE DF THE STANDART DEVIATION OF THETA IS 0.35451

AN ESTIMATE DF TIE SIANDARD DFVIATION DF SINE SOUARED THETA IS 0.0067 :

AN ESTIMATE OF THF STANDARD DEVIATION DF AZERO IS 0.01103

AN ESTIMATE TF THF STANIIARD DFVIATINN OF BZERT IS 0.00200

AN ESTIMATE DF THE STANDARJ DEVIATION DF CZERO IS 0.00477

I IWD THETA HH KK LL SINE SQUARED THETA SINE SQUARED THETA DIFFERENCE

$\begin{array}{rrrr}24.70900 & 0 & 0 & 4 \\ 30.80579 & 0 & 1 & 0 \\ 33.66440 & 1 & 1 & 1 \\ 35.16280 & 49 & 0 & 0 \\ 39.49959 & .36 & 0 & 4 \\ 43.03529 & 16 & 0 & 9 \\ 47.30330 & 49 & 1 & 0 \\ 48.92729 & 36 & 0 & 9 \\ 50.97449 & 0 & 0 & 16 \\ 54.57880 & 49 & 1 & 4 \\ 56.77939 & 121 & 0 & 0 \\ 58.35320 & 121 & 0 & 1 \\ 60.45499 & 36 & 0 & 16 \\ 62.72389 & 121 & 0 & 4 \\ 53.68309 & 49 & 0 & 16 \\ 65.18219 & 4 & 4 & 0 \\ 67.85659 & 9 & 4 & 1 \\ 68.99409 & 16 & 0 & 25 \\ 71.39789 & 25 & 4 & 1 \\ 73.99239 & 100 & 1 & 9 \\ 77.54410 & 16 & 1 & 25 \\ 79.86420 & 196 & 0 & 4\end{array}$

0.04578
0.07055
0.08395
0.09124
0.11413
0.13453
0.16094
0.17149
0.18517
0.21021
0.22607
0.23766
0.25345
0.27086
0.27833
0.29013
0.31154
0.32077
0.34050
0.36212
0.39216
0.41201

0.04657

0.07058

0.08419

0.09137

0.11370

0.13462

0.16205

0.17191

0.18629

0.20862

0.22562

0.23776

0.25342

0.27719

0.27766

0.20020

0.31116

0.32091

0.34100

0.36194

0.30160

0.41204

DIFFERENCE

EXEEUTION TIME $50.80 \mathrm{SEC}$. 
IC.E II I

THE FDLLOWING INDEXING IS ON THF EASIS OF THE ORTHORHOMBIC SYSTEM WITH THE ERROR LFSS THAN O.OOI829 THE LATTICE CONSTANT AZERO IS 1 T.80B65 ANGSTROMS.

THE LATTICE CONSTANT BIERO IS 7.14896. ANGSTROMS.

THE LATTICE CONSTANT CZERO IS 5.80120 ANGSTROMS.

THE UNRESOLVED WÁVELENGTH USED WAS 1.54180 AND THE K-ALPHA-ONE WAVELENGTH USED HAS 1.54051 THE DENSITY IS 1.000 THE FORMULA. WE IGHT IS 13.000, AND THE NUMBER IS 24.71.

THE FIRST D LINES ARE UNRESOLVED. THE REST ARE K-ALPHA-1 LINES.

AN ESTIMATE DF THE STANDARD DEVIATION DF THETA IS 0.03235

AN ESTIMATE OF THF STANDARD DEVIATION DF SINE SQUAREO THETA IS 0.00037

AN FSTIMATE DF THE STANDARO DEVIATION OF AZERO IS 0.01006

AN CSTIMATE DF THE STANDARD DEVIATION OF BZERT IS. 0.00293

AN ESTIMATF OF THE STANDARD DEVIATION OF CZERD IS 0.00210

I TWO THETA HH KK LL SINE SQUARED THETA SINE SQUARED THET
CALCULATED

$\begin{array}{rrrr}24.70900 & 0 & 4 & 0 \\ 30.80579 & 0 & 0 & 4 \\ 33.66440 & 1 & 1 & 4 \\ 35.16280 & 49 & 0 & 0 \\ 39.48959 & 36 & 4 & 0 \\ 43.03529 & 16 & 9 & 0 \\ 47.30330 & 1 & 0 & 9 \\ 48.92729 & 36 & 9 & 0 \\ 50.97449 & 0 & 16 & 0 \\ 54.57880 & 4 & 16 & 1 \\ 56.77939 & 36 & 0 & 9 \\ 58.35320 & 36 & 1 & 9 \\ 60.45499 & 36 & 16 & 0 \\ 62.72389 & 4 & 9 & 9 \\ 63.68309 & 64 & 0 & 9 \\ 65.18219 & 64 & 1 & 9 \\ 67.85669 & 16 & 0 & 16 \\ 68.99409 & 16 & 25 & 0 \\ 71.39789 & 25 & 1 & 16 \\ 73.99239 & 100 & 9 & 4 \\ 77.54410 & 100 & 4 & 9 \\ 79.86420 & 121 & 16 & 0\end{array}$

0.04578
0.07055
0.08385
0.09124
0.11413
0.13453
0.16094
0.17149
0.18517
0.21021
0.22607
0.23766
0.25345
0.27086
0.27833
0.29013
0.31154
0.32077
0.34050
0.36212
0.39216
0.41201

0.07052

0.08400

0.09166

0.11378

0.13441

0.16053

0.17182

0.18574

0.21085

0.22601

0.23762

0.25308
0.27062

0.27839

0.29000

0.31200

0.32015

0.34044

0.36207

0.39217

OIFFERENCE

EXECUTION TIME

96.06 SEC. 
ICE II I

THE FOLLOWING INDEXING IS ON THF BESIS OF THE ORTHORHOMBIC SYSTEM WITH THE FRROR LESS THAN O.OOOGI

THE LATTICE CONSTANT AZERC IS 13.92603 ANGSTROAS.

THE LATTICE CONSTANT BZFPO IS 8.87462 ANGSTROMS.

THE LATTICE CONSTANT CIERO IS 6.84152 ANGSTROMS.

THE UNRESTLVE WAVELENGTH USED WAS 1.54180 AND THE K-ALPHA-DNE WAVELENGTH USFD WAS 1.54051

THE DEMSITY IS 1.000 THE FOFMULA HEIGHT IS 18.000, AND THE NUPBER IS 28.29.

THE FIRST 0 LINES ARF UNRESOLVED. THE REST ARE K-ALPHA-1 LINES.

AN ESTIMATE OF THF STANOARD DEVIATION OF THETA IS 0.02203

AN ESTIMATE RF THF STANOARO DEVIATION OF SINE SQUARED. THETA IS 0.00031

AN FSTIMAIE TF THE CTANDARO DEVIATION DF AZERO IS $0.0 \cap 365$

AN FSETMATE TF THE SIANDARD OEVIATION OF BZERD IS 0.00434

AN ESIIMATE OF THE STANDARD DEVIATION DF CZERO. IS 0.00225

I TNO THETA HH KK LL SINE SOUARED THETA SINE SQUARED IHETA DIFFERFNCE

$\begin{array}{rrrrrrr}24.7 n 900 & 1 & 4 & 1 & 0.04578 & 0.04587 & -0.00009 \\ 30.80579 & 4 & 1 & 4 & 0.07055 & 0.07047 & 0.00007 \\ 33.66440 & 1 & 4 & 4 & 0.08385 & 0.08389 & -0.00004 \\ 35.16780 & 16 & 4 & 1 & 0.09124 & 0.09173 & -0.00051 \\ 39.48959 & 0 & 0 & 9 & 0.11413 & 0.11408 & 0.00005 \\ 43.03579 & 25 & 1 & 4 & 0.13453 & 0.13472 & -0.00018 \\ 47.30330 & 36 & 0 & 4 & 0.16094 & 0.16083 & 0.00011 \\ 48.92729 & 9 & 4 & 9 & 0.17149 & 0.17174 & -0.00025 \\ 50.97449 & 1 & 9 & 9 & 0.18517 & 0.18494 & 0.00023 \\ 54.57880 & 0 & 1 & 16 & 0.21021 & 0.21034 & -0.00013 \\ 56.77939 & 64 & 4 & 0 & 0.22607 & 0.22592 & 0.00014 \\ 58.35320 & 1 & 16 & 9 & 0.23766 & 0.23767 & -0.00001 \\ 60.45499 & 64 & 1 & 4 & 0.25345 & 0.25403 & -0.00058 \\ 62.72389 & 1 & 9 & 16 & 0.27086 & 0.27060 & 0.00026 \\ 63.68309 & 8 ! & 4 & 0 & 0.27833 & 0.27793 & 0.00040 \\ 65.18219 & 81 & 4 & 1 & 0.29013 & 0.29061 & -0.00047 \\ 67.85669 & 9 & 36 & 1 & 0.31154 & 0.31140 & 0.00014 \\ 68.99409 & 49 & 16 & 4 & 0.32077 & 0.32113 & -0.00037 \\ 71.39789 & 54 & 4 & 9 & 0.34050 & 0.34000 & 0.00050 \\ 73.99239 & 91 & 0 & 9 & 0.36212 & 0.36188 & 0.00024 \\ 77.54410 & 91 & 4 & 9 & 0.39216 & 0.30201 & 0.00015 \\ 79.86420 & 9 & 9 & 25 & 0.41201 & 0.41222 & -0.00021\end{array}$

EXECUTION TIME 233.26 SEC. 
THE FOLLOWING INDEXING IS ON THE BASIS OF THE ORTHORHOMBIC SYSTEM HITH THE ERROR LESS THAN O.OOO9I4 THE LATTICE CONSTANT AZFRO IS THE LATTICE CONSTANT BZFRO IS

13.92603 ANGSTROMS.

THE LATTICE CONSTANT CZFRO IS

8.87462 ANGSTROMS.

6.84152 ANGSTROMS.

THE INRESOLVED WAVELENGTH USFD WAS 1.54180 AND THE K-AL PHA-ONE HAVELENGTH USED WAS 1.54051 THE DENSITY IS 1.0ON THE FORMULA WEIGHT IS 18.000, ANO THE NUMBER IS 28.29.

THE FIRST i LINES ARE UNRESOLVED. THE REST ARE K-ALPHA-1 LINES.

AN ESTIMATE DF THE STANDARD DEVIATION OF THETA IS 0.02203

AN ESTIMATE OF THE STANDARD DEVIATION OF SINE SOUARED THETA IS

AN ESTIMATE OF THE STANDARD DEVIATION OF AZERO IS 0.00365

AN ESTIMATE OF THE STANDARD DEVIATINN OF BIERO IS 0.00434

AN ESTIMATE OF THE STANDARD DEVIATION OF CZERO IS 0.00225

MBSERVED THO THETA HH KK LL SINE SQUARED THETA SINE SOUARED THETA
I TWO SULATED

\subsection{1}

$\begin{array}{rrrrr}1 & 24.70900 & 1 & 4 & 1 \\ 2 & 30.85579 & 4 & 1 & 4 \\ 3 & 33.66440 & 1 & 4 & 4 \\ 4 & 35.16230 & 16 & 4 & 1 \\ 5 & 39.48959 & 0 & 0 & 9 \\ 6 & 43.03529 & 25 & 1 & 4 \\ 7 & 47.30330 & 36 & 0 & 4 \\ 8 & 48.92729 & 9 & 4 & 9 \\ 9 & 50.97449 & 1 & 9 & 9 \\ 10 & 54.57830 & 0 & 1 & 16 \\ 11 & 56.77939 & 64 & 4 & 0 \\ 12 & 58.35320 & 1 & 16 & 9 \\ 13 & 60.45499 & 64 & 1 & 4 \\ 14 & 62.72389 & 0 & 9 & 16 \\ 15 & 63.68309 & 91 & 4 & 0 \\ 16 & 65.18219 & 81 & 4 & 1 \\ 17 & 67.85669 & 9 & 36 & 1 \\ 18 & 68.99409 & 49 & 16 & 4 \\ 19 & 71.39789 & 64 & 4 & 9 \\ 20 & 73.99239 & 81 & 0 & 9 \\ 21 & 77.54410 & 81 & 4 & 9 \\ 22 & 79.86420 & 9 & 9 & 25\end{array}$

DIFFEREVCE

EXECUTION TIME $310.57 \mathrm{SEC}$.

$\begin{array}{ll}0.04578 & 0.04587 \\ 0.07055 & 0.07047 \\ 0.08385 & 0.08389 \\ 0.09124 & 0.09176 \\ 0.11413 & 0.11408 \\ 0.13453 & 0.13472 \\ 0.16094 & 0.16083 \\ 0.17149 & 0.17174 \\ 0.18517 & 0.18494 \\ 0.21021 & 0.21034 \\ 0.22607 & 0.22592 \\ 0.23766 & 0.23767 \\ 0.25345 & 0.25403 \\ 0.27086 & 0.27060 \\ 0.27833 & 0.27793 \\ 0.29013 & 0.29061 \\ 0.31154 & 0.31140 \\ 0.32077 & 0.32113 \\ 0.34050 & 0.34000 \\ 0.36212 & 0.36188 \\ 0.39216 & 0.39201 \\ 0.41201 & 0.41222\end{array}$

$$
\begin{array}{r}
-0.00009 \\
0.00007 \\
-0.00004 \\
-0.00051 \\
0.00005 \\
-0.00013 \\
0.00011 \\
-0.00025 \\
0.00023 \\
-0.00013 \\
0.00014 \\
-0.00001 \\
-0.00058 \\
0.00026 \\
0.00040 \\
-0.00047 \\
0.00014 \\
-0.00037 \\
0.00050 \\
0.00024 \\
0.00015 \\
-0.00021
\end{array}
$$


APPENDIX C. PROGRAM LISTING 
C PRMGRAM INDEX

DIMENSION THO TH $(150), S(150), S 2 S 0(1.50)$, NAME 18$)$, EL $(60), E S(530)$

INTE $; E R * 2 . K 9(1256,9)$

COMMON EL, THO TH, MAME,S2SO,NCUT, XLAMDA, YLAMDA, MI, ETFST, TETBLK,

*S, ES, FORMWT, DENSTY, KO, NIICUBE, NOHEX, NONO

1 CONTINUE

CALL TZERO

C GFNERATF THE L LIST OFF ALL LL

ก) $5 \mathrm{I}=1,30$

$5 E L(I)=(I-1) *(I-1)$

$7000 \operatorname{PPAD}(5,7001)((K 9(I L, I C K), I C K=i, 9), I L=1,3.255)$

7001 FORMAT(8011)

10 CONTI INUE

CALL INPIIT

20 CONTINUF.

IF (NOCUSF) $30,25,30$

25 CMNTINUE

CALL CUBIC

30 CONTINUE.

CALL HEXTET

CINT INUF.

IFANONO) $10,40,10$

40 COMTINUUE

CALL ORTHO

(S) TO 10

END 


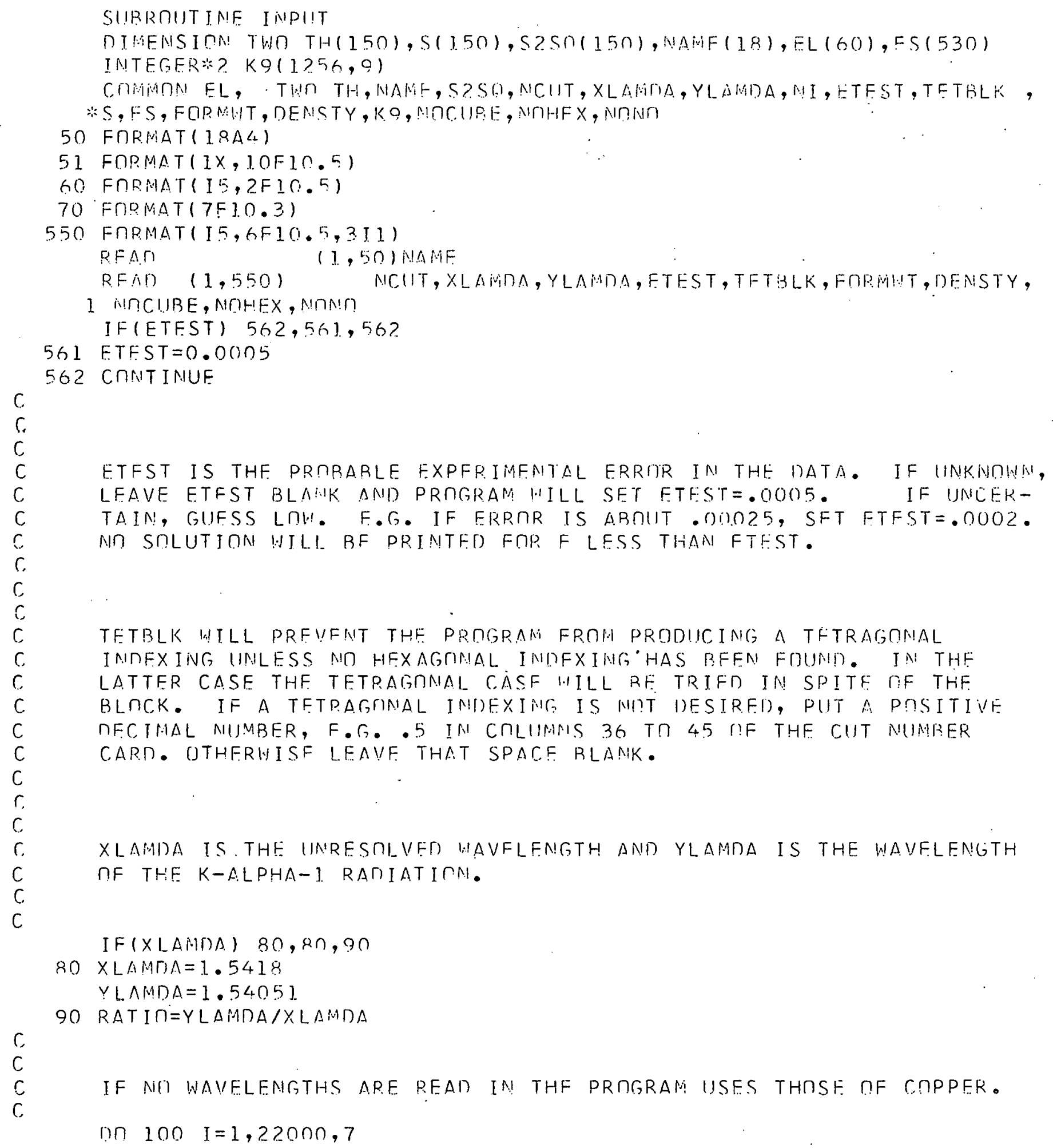


$J=\mathrm{T}+6$

READ $\quad(1,70)(T W \cap T H(K), K=T, J)$

IF(ABS (TWDTH(I) ) + ABS (TWOTH(I+1)) +ABS (TWOTH(I+2)) + ABS (TWOTH(I+3

$X))+\triangle B S(T W O T H(I+4))+A B S(T W O T H(I+5))+A B S$ (TWOTH(J))) I00,150,100

100 CONTINUE

150 Dก $200 \quad \mathrm{~J}=1,7$

$N=I-J$

IF(TWO TH(N)) $250,200,250$

200 CONTINUE

$250 N I=$ MINO $(N, 150)$

IF (NCUTT $300,300,280$

280 DO $290 \mathrm{I}=1, \mathrm{NCUT}$

$S(I)=($ RATIO **2) *SIN (TWO TH(I) *8.726646E-3) **2

S2SO(I) $=$ SIN (TWO TH(I)*1.745329F-2)**2

290 CONTINUE

IF (NCUT E EQ. NI) Gח TO 310

300. NKUT $=\mathrm{N}: \mathrm{CUT}+1$

DO $310 \quad I=$ NKUT, $N I$

$S(I)=S I N$ (TWO TH(I) *8.726646E-3) $* * 2$

S2SO(I) $=$ SIN (TWO TH(I) *1.745329F-2.)*2

310 CONTINIUE

$M A R K=8$

RETURN

END 


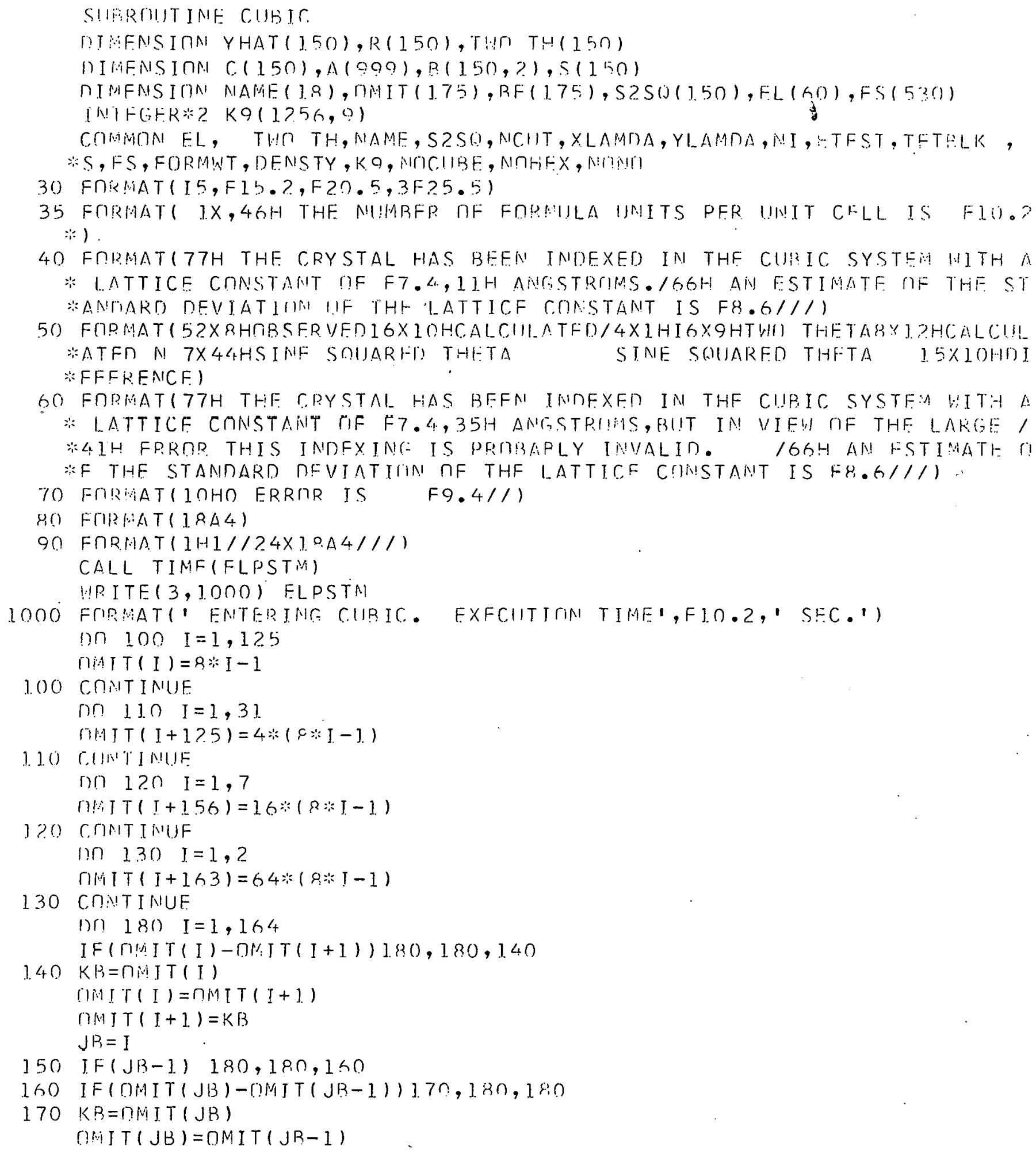




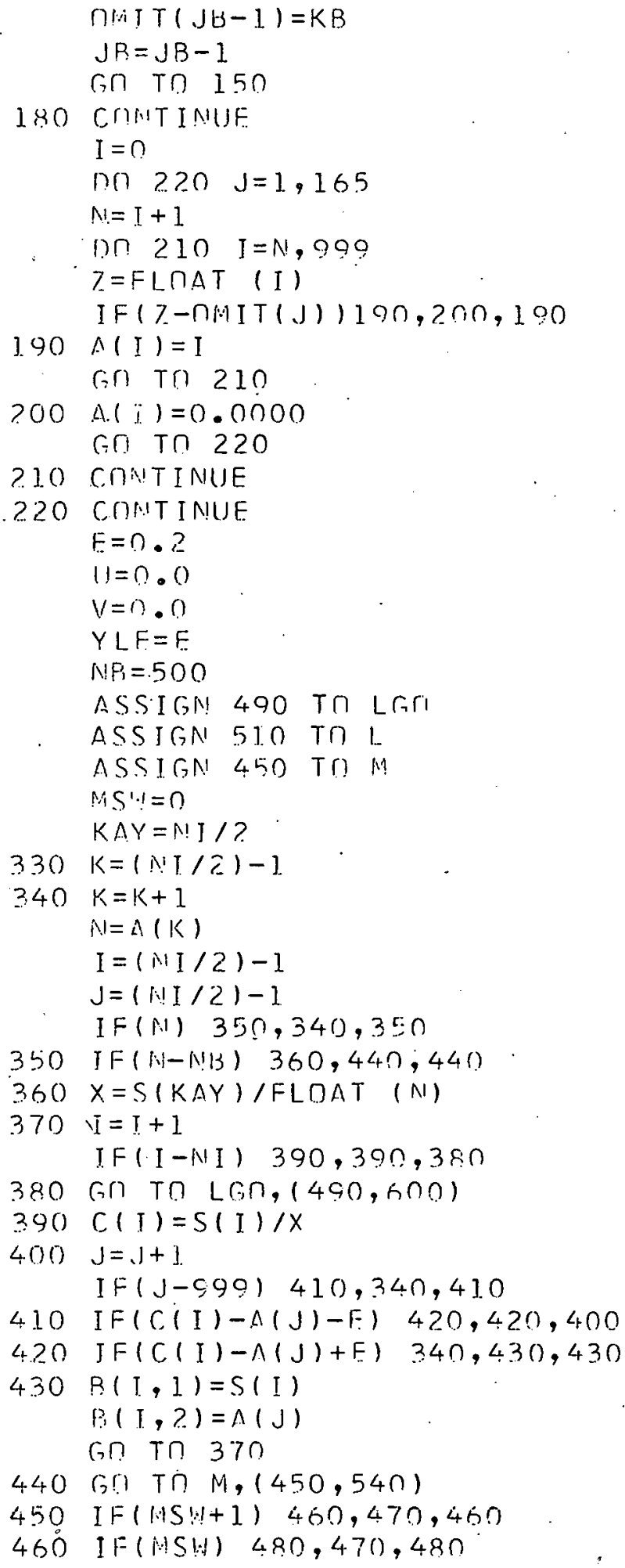




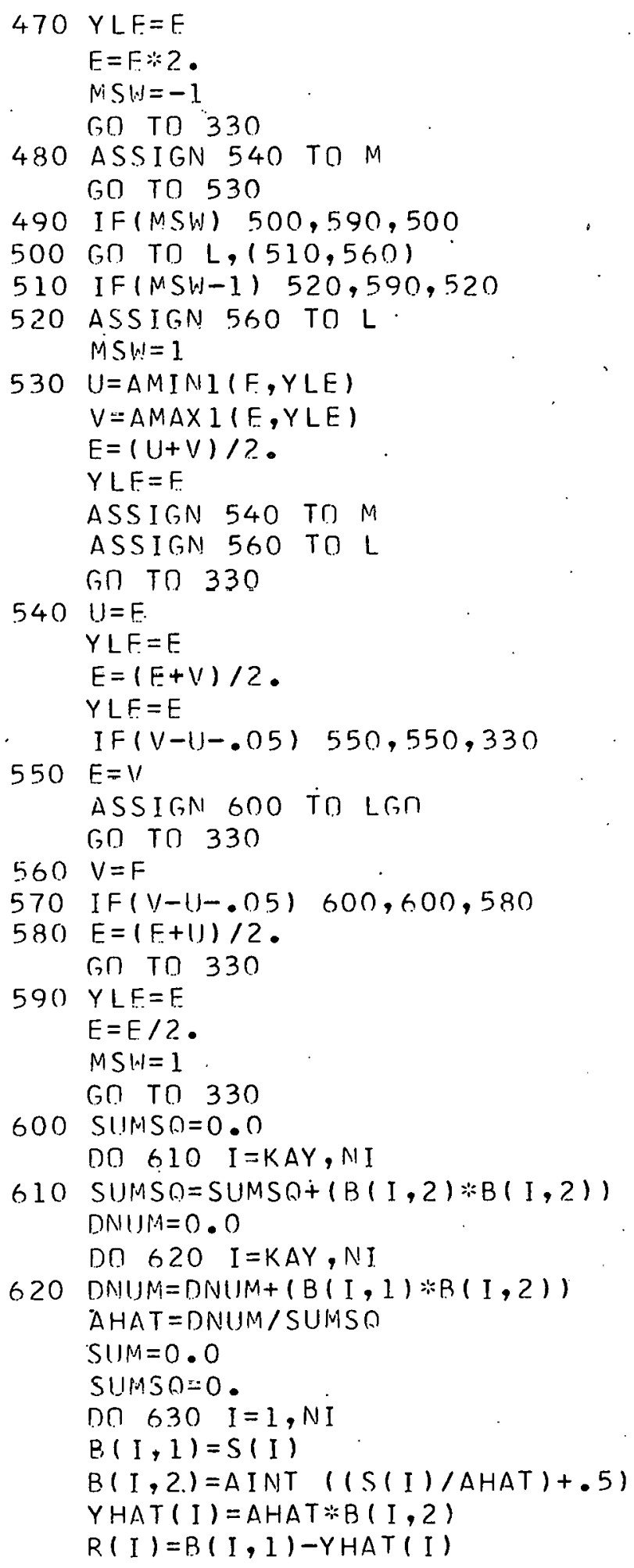




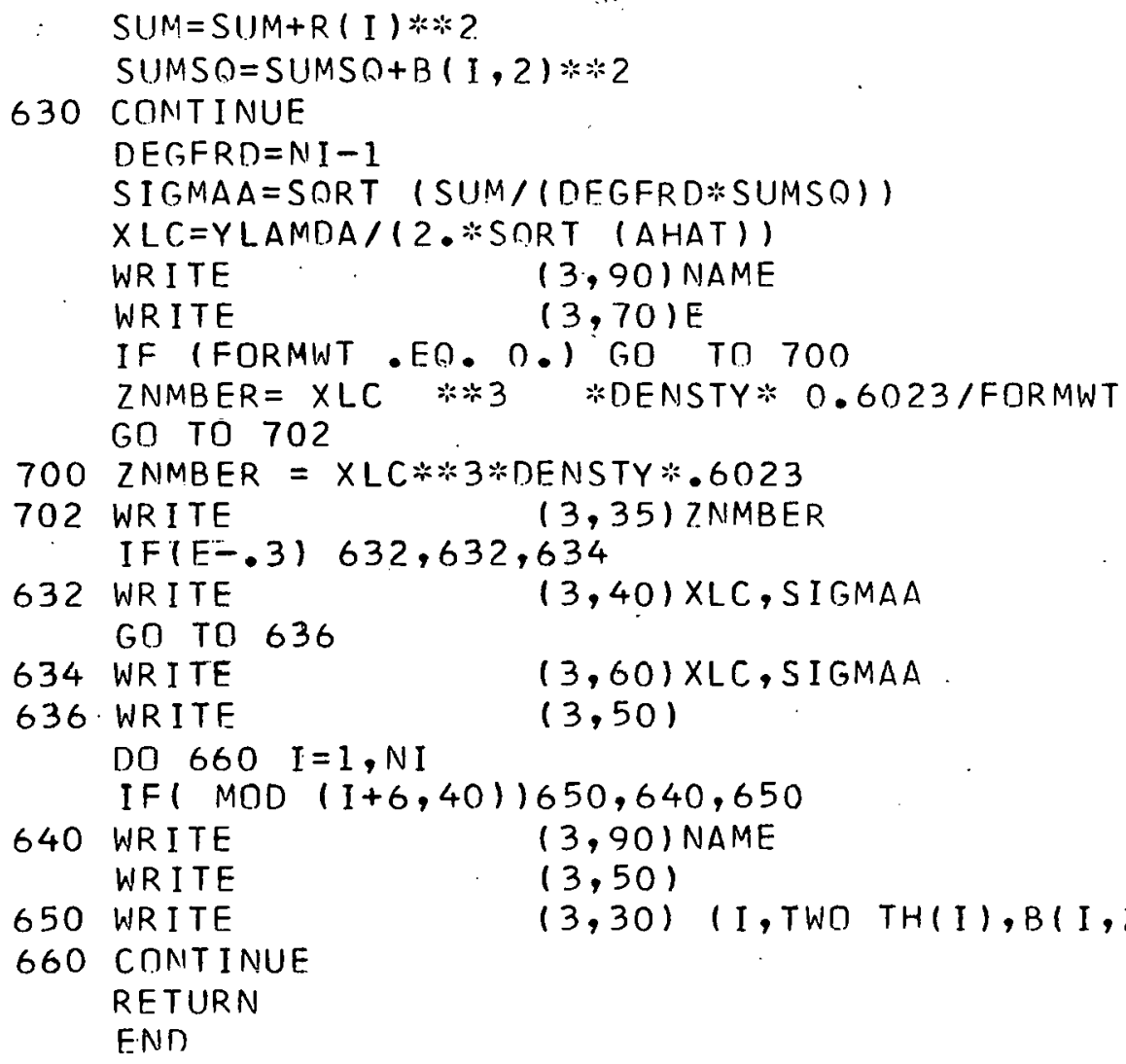


SIIRROIIT INE HEXTFT

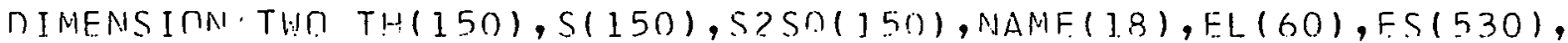
*O(150), D(150), A (150,2),KA $(150,2), A S T \cap R(25), C S T R R(25), F A C T \cap R(25)$, $\because C(150)$

C. PRTGRAM TO DFTFRMINF. CRYSTAL IMIDFXFS, HFXAGIINAL CASE

INTFGFR*2 K9(1256,0)

COMMON FL, .TWO TH, MAMF, S2SG, NCIIT, XLAMIIA, YLAMDA, NI, FTFST, TFTBLK, *S, ES, FORMWT, DENSTY, K 9 , NOCHBE, NOHFX, NONON

500 FORMAT (44X9H ORSFRVFD15X10HCALCULATFD/

*2X 1 HI $4 \times$ OHTWO THFTA $4 \times 8 H H H+K K+H K 5 \times 2 H L L 5 \times 18 H S I M F$ SOUARFO THFTA

$\times 5 \times 18 H S I N F$ SOUARED THETA $8 \times 10 H D I F F F R F N C E / /)$

505 FORMAT (44X9H ORSFRVFD15XIOHCALCIULATED)

$\because 2 \times 1$ III $4 \times 9 H T W I T$ THFTA $4 \times 5 H H H+K K \quad 8 \times 2 H L L 5 \times 18 H S I M F$ SOUIARFD THFTA

$X 5 \times 18 H S I N F$ SOUARFD THETA $8 \times 10 H D I F F I R F N C F / / 1$

510 FחPMAT (1XI 3,F11.3, 2. I I0,F2.0.5,F23.5,F20.5)

511 FMPMAT (ONHOTHF FחLLMWING INDFXING IS ON THE RASIS OF THF TETRAGONA *L. SYSTEM WITH THF FRRMK LESS THAN FB.6)

512 FOPMATI 8ЯHOTHE FחLLOWING INDEXING IS ON THE RASIS IIF THE HFXAGDNAL * SYSTFM WITH THF FRRMR LFSS THAN FR.6)

515 FORIAT $164 H$ AN FSTIMATE OF THE STANDARD DEVIATION OF SINF SOUARFD T *HETA IS F10.4/5.1H AN ESTIMATE MF THF STANDARD DEVIATION OF THETA I *S F10.4/51H AN FSTIMATE IIF THF STAMDARD DEVIATION DF AZERO IS

*F10.4/51H AN FSTIMATF IF THE STAMMARD DEVIATION OF CZFRO IS $\because F 10.4 / 9 H !$ AHAT IS FIO.6,?X9H RHAT IS F10.6/31HOTHE LATTICF CONSTANT * ATFRT IS F10.5, 11H ANGSTRMMS./31HOTHF LATTICF CONSTANT CZFRO IS $\because F 1 \cap .5,11 H$ AN!GSTRMMS.//1

520 FIRPAT (36HOTHE IINRESOLVEN WAVFLENGTH IISEO WAS F8.5,41H AMD THE K-A $\because$ :PHA-ONE WAVELENGTH USED WAS F8.5/16H THE DENSITY IS F6.3, $1 \mathrm{H}, 2.2 \mathrm{H}$ *THF FORMULA HEIGHT IS F8.3,21H, AND THE NUMBER IS F6.3, 1H.)

525 FORMAT (IIHOTHE FIRST I 3,53H LINES ARE UNRESIILVED. THE RFST ARE K-A *LPHA-I LINFS. )

537 FORMAT (97HOTHF DROGRAM IS UNABLE TI INDEX THE CRYSTAL ON A HEXAGTN *AL BASIS IITHIN THF MAXIMIIM FRRחR חF F10.51

538 FORMAT 193 HOTHF PROGRAM IS IJNASLF TRI INDFX THF CRYSTAL ON A TETRAGO :NAL BASIS :ITHJN THF MAXIMUMM ERRIR MF FIO.5I

539 FMRHATI G4HOTHF PRIGRAM IS IINARLF TO INDEX THE CRYSTAL WITHIN THE E :RPIIR ITF FR. 6$)$

558 FORMAT( 1 HI/24X1PA4//)

CALL TIMF(FLPSTM)

WR. ITF $(3,1010)$ FLPSTM

1010 FOIRMATI// FNTFRING HEXTFT. FXFCUTION TIME',FIO.2, SEC.'

NSTOR, $=0$

NSTORE $=0$

$K K K K=0$

C GFI SFT FOR THE HEXAGUNAL CASE.

$R=1$. 0

$K T=1$

C GFNERATF THE $S$ LIST OTF ALL HH+KK+HK 
IF (NOHEX) $702,584,702$

$584 \mathrm{I}=0$

$M A Y=1$

$K A Y=1$

DO .592 $M=1,32$

Dก $591 \mathrm{~K}=1, \mathrm{M}$

$I=I+I$

$E S(I)=(M-1) *(M-])+(K-1) *(K-1)+K T *(M-1) *(K-1)$

591 CONTINUF

592 CONTINUF.

DO $593 \mathrm{~K}=1,25$

$A S T \cap R(K)=0$.

$\operatorname{CSTRR}(K)=0$.

593 CONTINUE

ASSIGN 727 TO KSKIP

C ORDER. THF S LIST

DO $12117=1,527$

$I Z I=I Z+1$

Dก $121 \mathrm{JZ}=\mathrm{IZI}, 5 ? 8$

$I F(E S(I Z)$. LT. FS (JZ)) GO TO 1?.I

$T E M P=F S(I Z)$

$E S(I Z)=E S(J Z)$.

$E S(J 7)=$ TEMP

121 CONTINUF

$L P=0$

DO $3 \quad I=2,277$

$594 \operatorname{IF}(E S(I-1)-E S(I)) 3,1,800$

1. $L P=L P+1$

$M=529-L P$

$n \cap 2 \mathrm{~J}=\mathrm{I}, \mathrm{M}$

$E S(J-1)=E S(J)$

2 CONTINUE

GO TI 594

3 CONTINUE.

COIMMANDS 594 TO 3 DELFTE DUPLICATE INTFGERS.

NIES $=277$

NFI. $=30$

$B=1.0$

- $\quad \Pi \pi \quad I=2, N I$

$D(I)=A B S(S(I)-S(I-1))$

$B=A M I N I(B, D(I))$

4 CONTINUE

C B IS THF MINIMIM DIFFERENCE BLIWEEN SII) AND $S(I+1)$. $5 E=.49 * B$

CTIMMANDS TO HERE FIX THE MAXIMUM ERROR E $Y L F=4 . * E$

$\mathrm{KAT}=0$

C KAT IS INCREASED BY 1 WHEN WE FAIL TO INDEX THE CRYSTAL. 


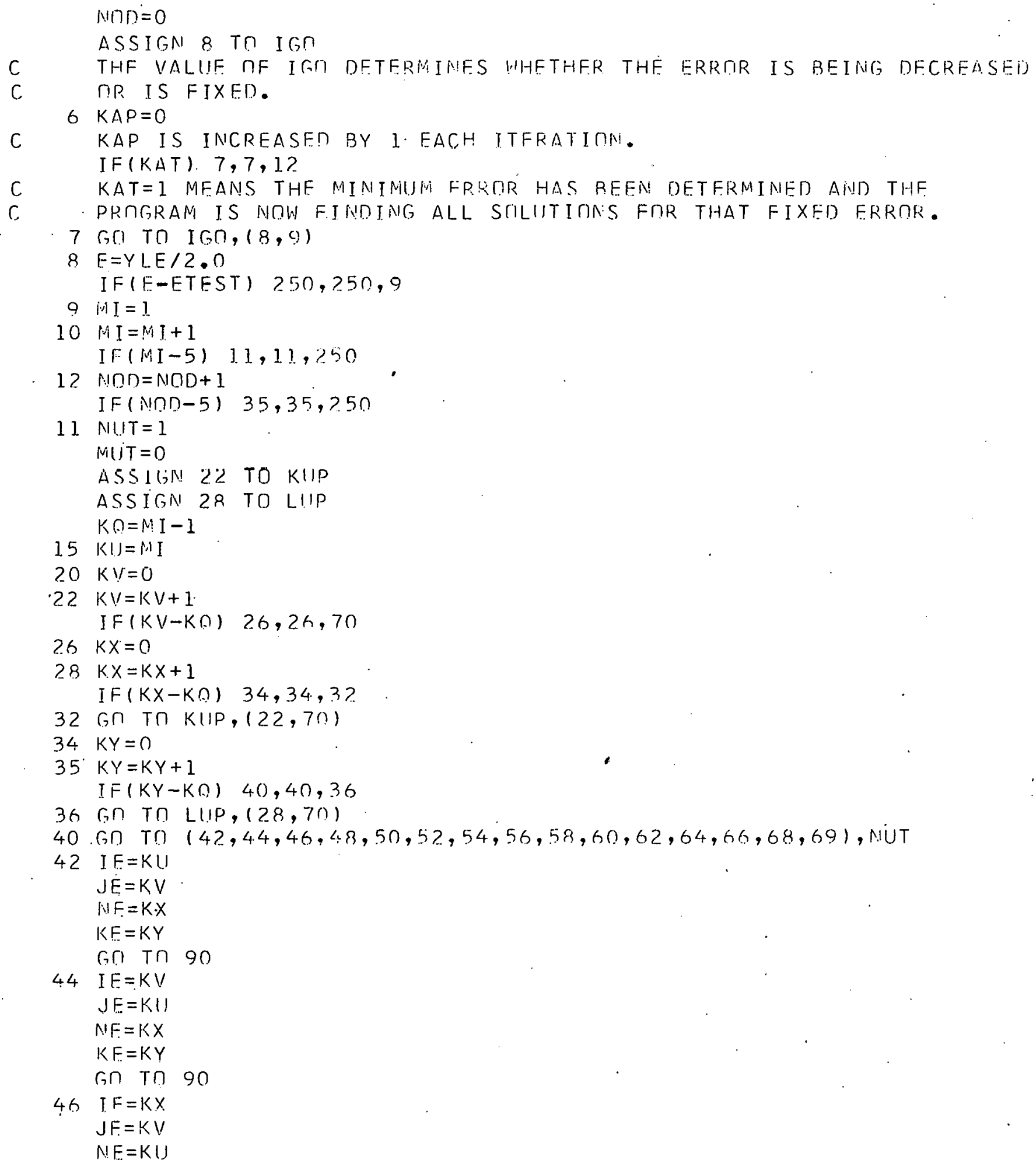




$$
\begin{aligned}
& K F=K Y \\
& \text { GD TO } 90 \\
& 48 \text { I } E=K V \\
& J F=K X \text {. } \\
& N F=K Y \\
& K E=K U \\
& \text { GO TO } 90 \\
& 50 \mathrm{~J} E=K U \\
& J F=K V \\
& N E=K X \\
& K E=K Y \\
& \text { SO TO } 90 \\
& J F=K U \\
& N E=K Y \\
& K E=K V \\
& \text { GO TO } 90 \\
& 54 \text { I } F=K U \\
& J F=K X \\
& N E=K V \\
& K E=K Y \\
& \text { GI TO } 90 \\
& 56 \text { I } E=K X \\
& J F=K Y \\
& N E=K U \\
& K E=K V \\
& \text { Gח TO } 90 \\
& 58 \quad I F=K X \\
& J F=K U \\
& N F=K V \\
& K E=K Y \\
& \text { GO TO } 90 \\
& 60 \text { I } E=K U \\
& J F=K X \\
& N E=K Y \\
& K E=K V \\
& \text { GO TO } 90 \\
& 62 I E=K U \\
& J E=K V \\
& N E=K X \\
& K E=K Y \\
& 60 \text { TO } 90 \\
& 64 \mathrm{IE}=K \mathrm{~J} \mathrm{~J} \\
& J E=K V \\
& N F=K Y \\
& K E=K X \\
& \text { GD TO } 90 \\
& 66 \mathrm{IF}=\mathrm{K}(\mathrm{I}
\end{aligned}
$$




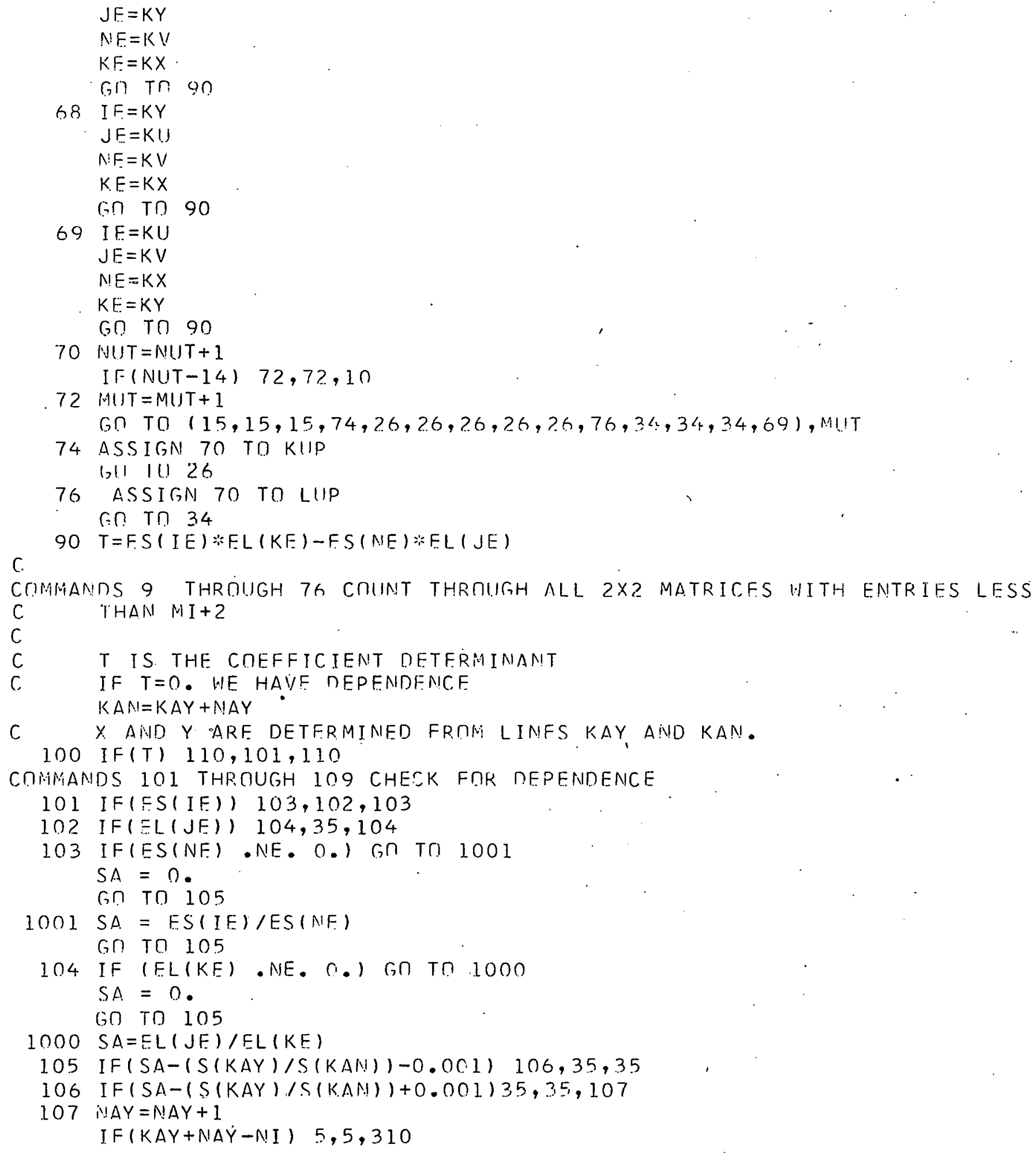




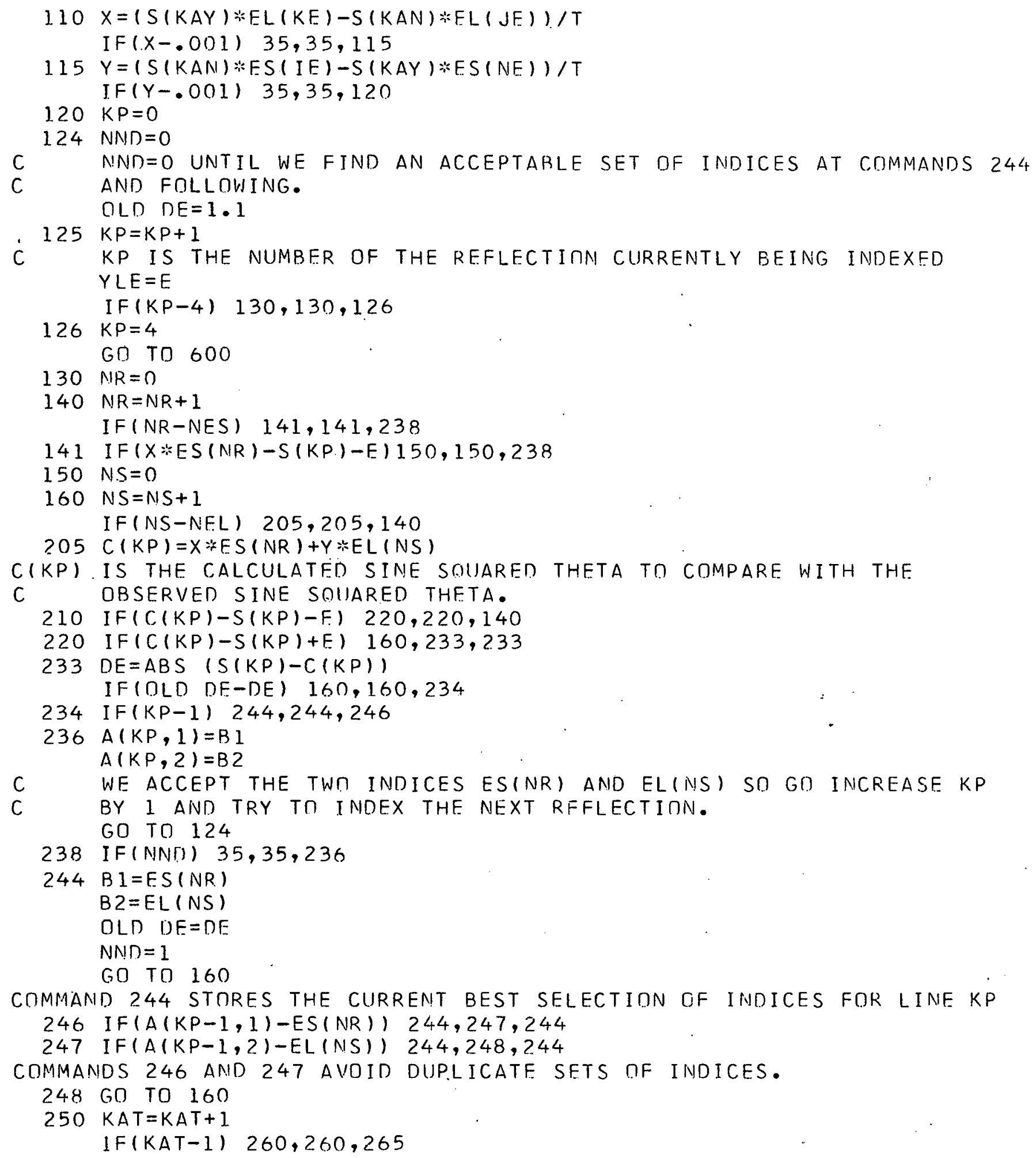




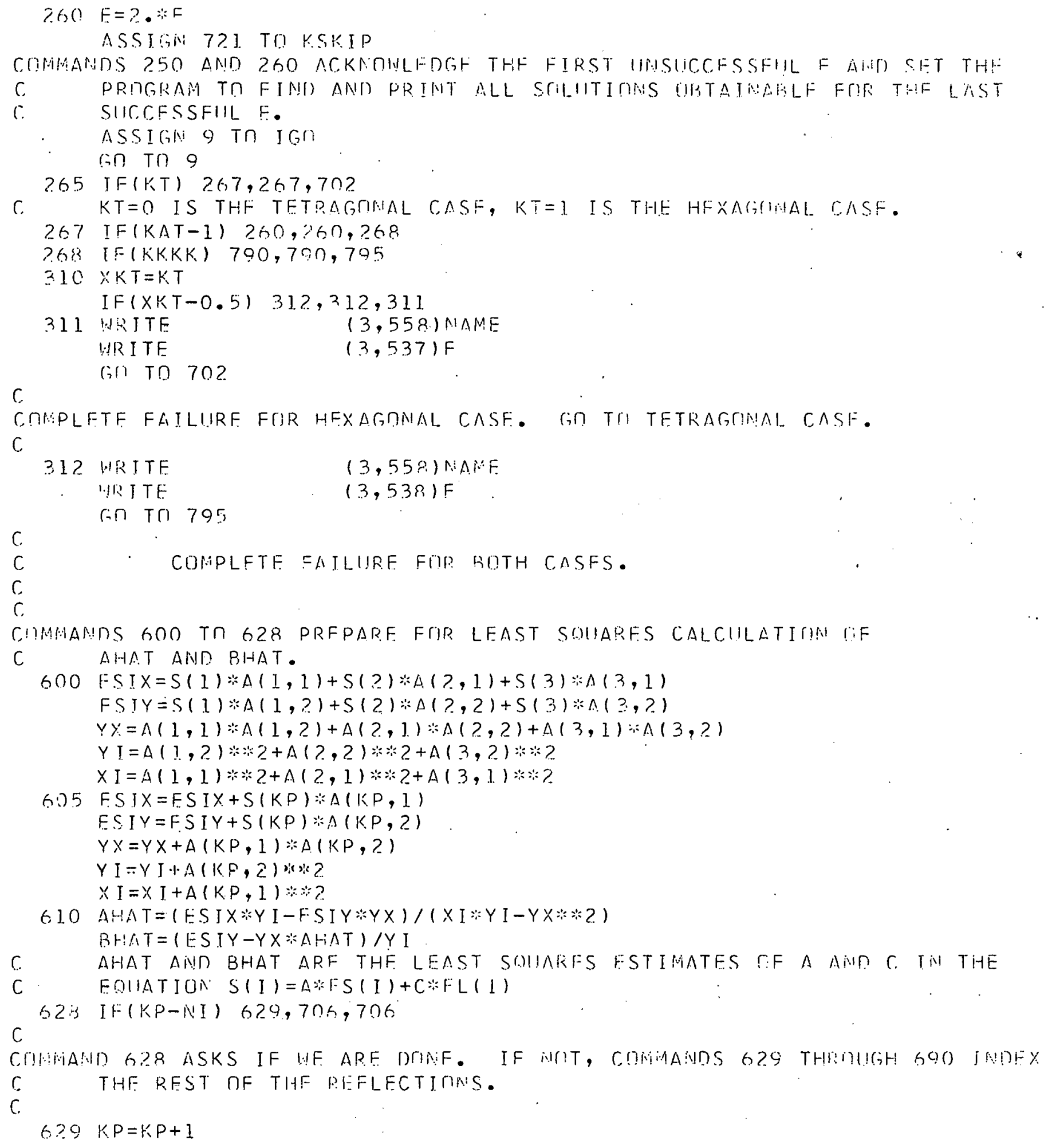




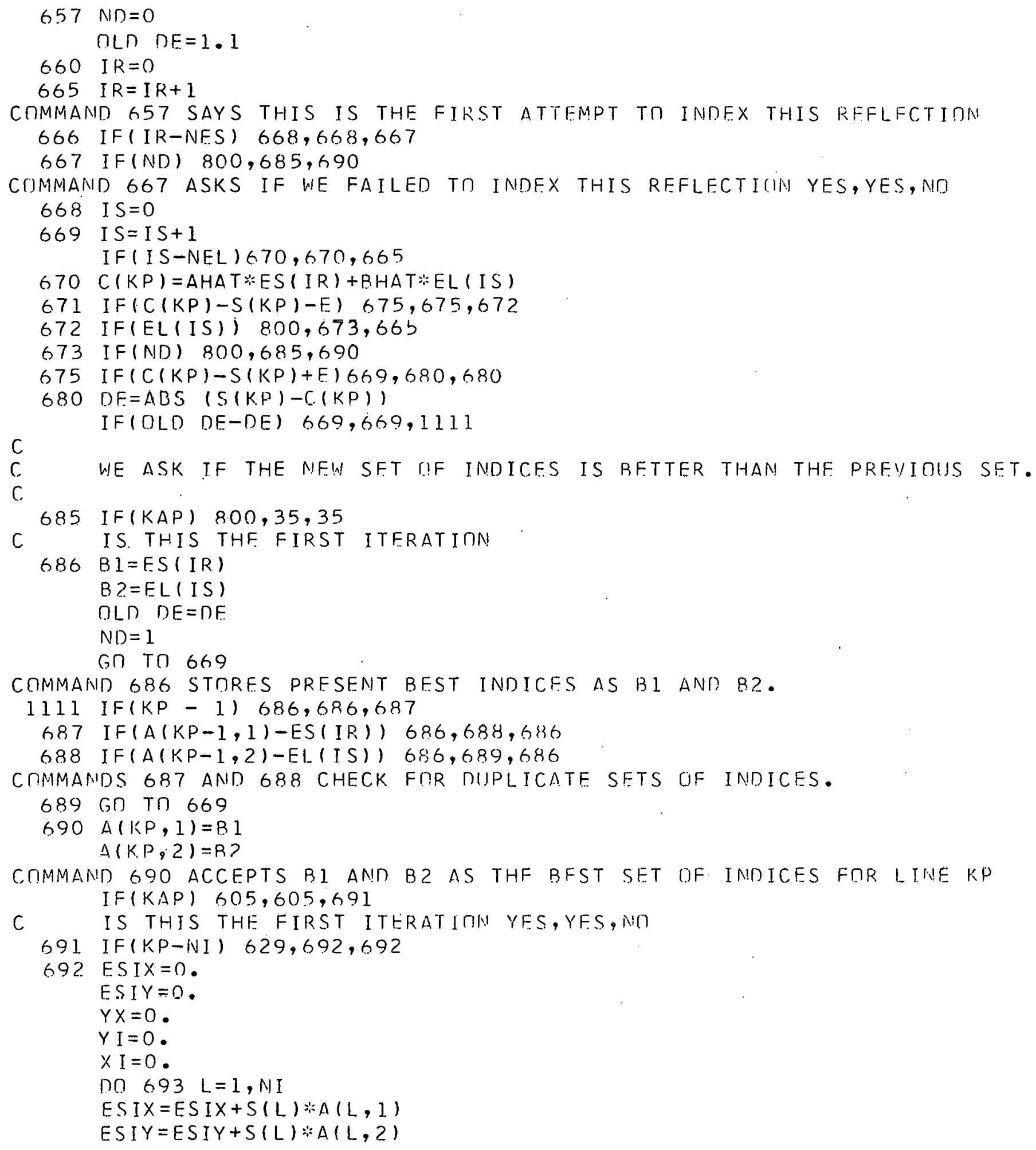




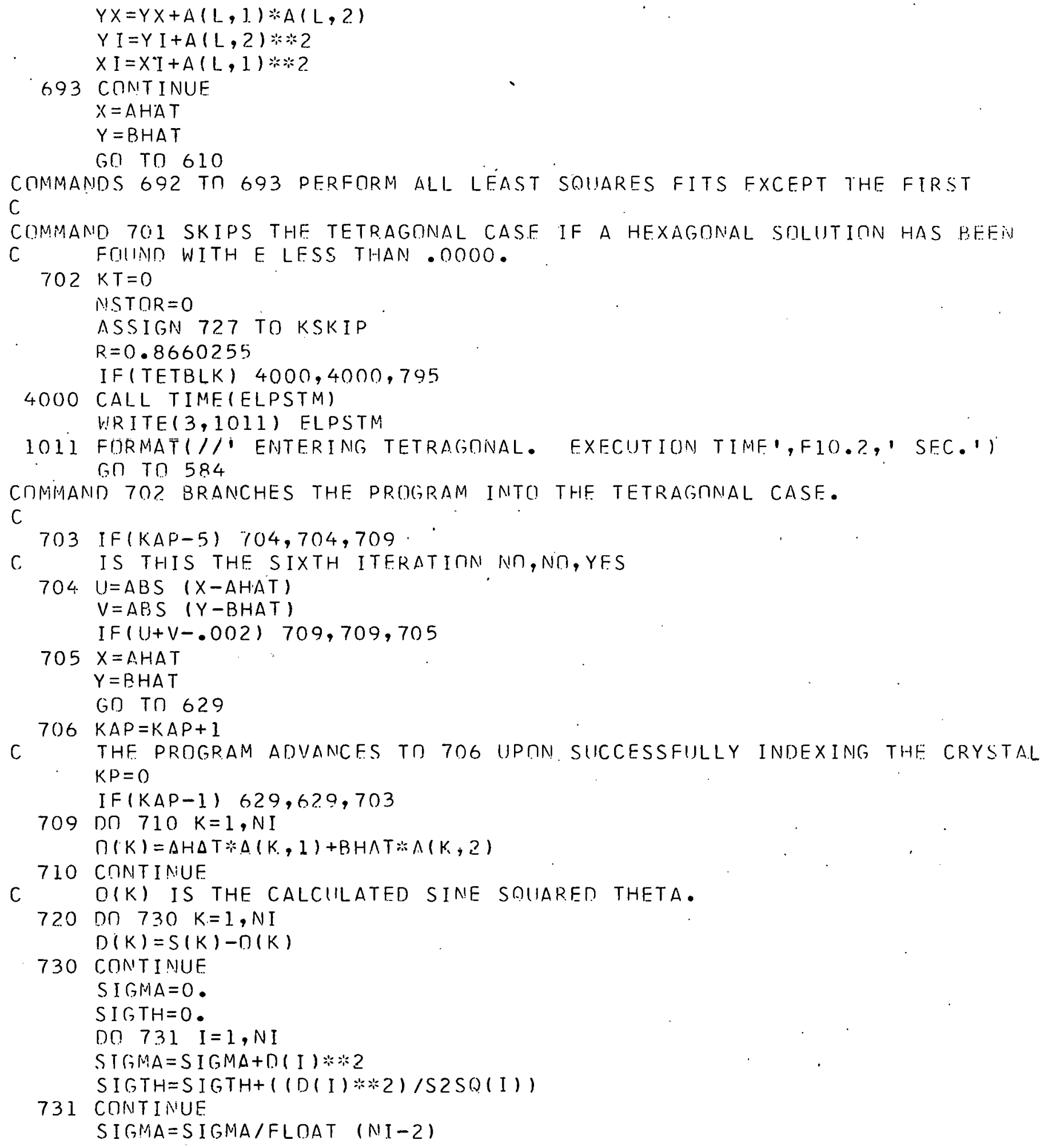




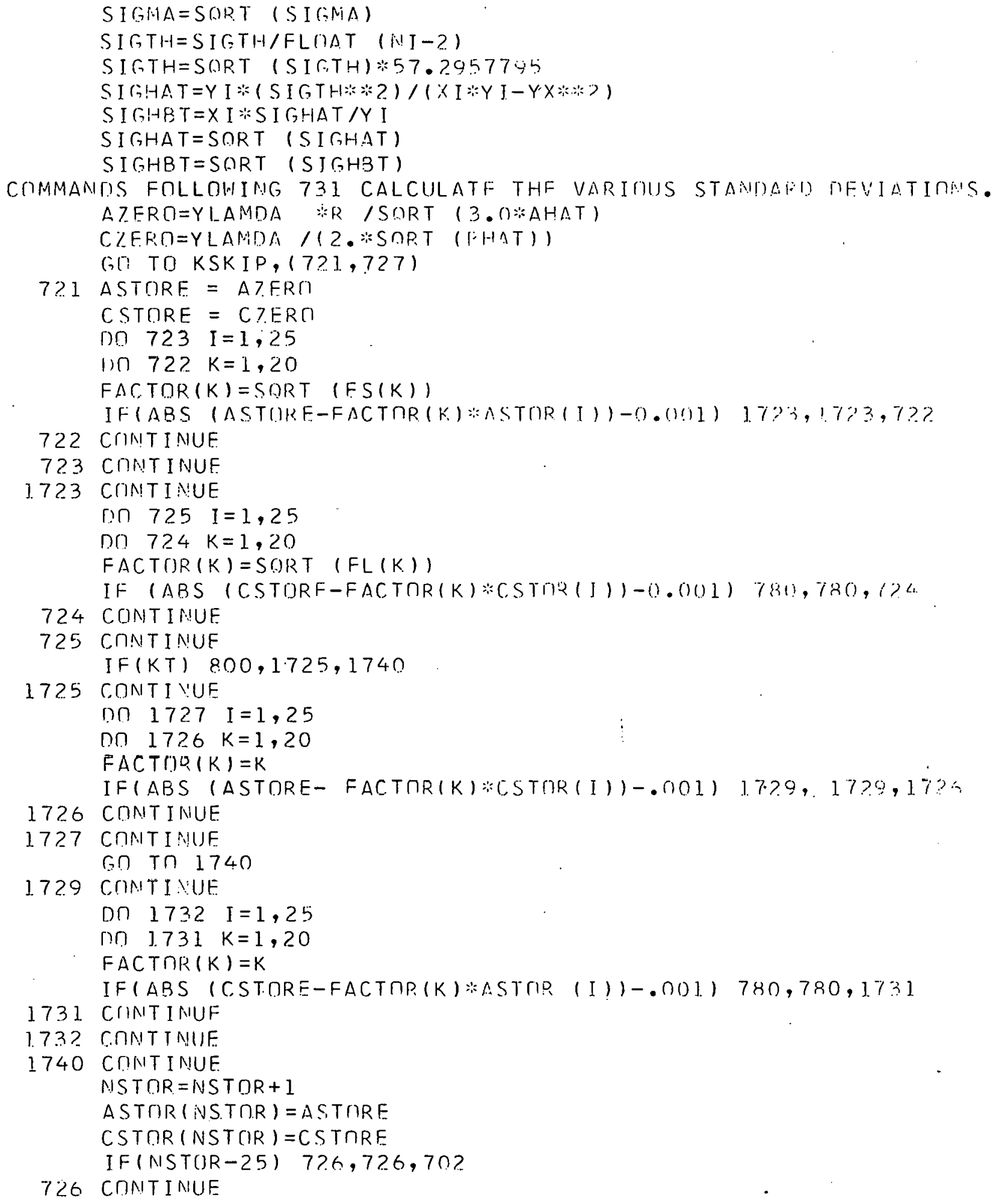


C.

C

C

C

INCE THE MINIMIJM ERROR HAS BEFN DETERMINEN, THE COMMANDS FROMA

721 TO 727 WILL ELJMINATE SOLIITIMNS WHICH ARF MULTIPLFS MF.

PREVIQUSLY ACCEPTED SOLUTJONS FOR THAT FRROR.

SIGAZO=AZERO*SIGHAT/(2.*AHAT)

$S I(; C Z O)=C Z E R O * S I G H B T /(2 . * B H A T)$

DO $732 . I=1, N I$

$\operatorname{KA}(I, 1)=A(I, 1)$

$K A(I, 2)=A(I, 2)$

732 CONT INUE

733 WRTTE $\quad(3,558) \mathrm{NAME}$

IF $(K T-1) 734,735,735$

C WAS THIS CASE HEXAGONAL OR TETRAGMNAL

734. WRITE $(3,511) \mathrm{E}$

ASSIGN 762 TO KK

ASSIGN 774 TO KKK

VOLUMF $-\Lambda$ Z EPO: CZERO:AZERO

GO TO 740

735 WRITE $\quad(3,512) \mathrm{F}$

ASSIGN 764 TO KK

ASSIGN 776 TO KKK

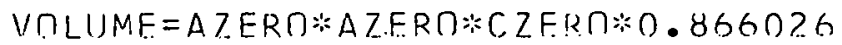

740 CINTI INUE.

741 IF(FחRMWT) $742,742,744$

742 ZNMBFR = VOLUME:DENSTY*.6023

GO TO 755

744 CONT INUE

ZNMBER = VOLUME $\because$ DENSTY $\div 0.6023 / F \cap R M ! n T$

755 CONTINUF

WRITE $(3,520) \times L A M D A, Y L A M D A, D E N S T Y, F O R M W T, Z N M B F R$

WR JTF $\quad(3,525)$ M!CIJT

I.IRITE (3,515) SIGMA,SIGTH,SIGAZח,SIGCZO, AHAT, RHAT,AZERO

$\therefore, C$. T.ERO

$760 \cdot \mathrm{GO} T \mathrm{THK},(762,764)$

762 l.

GO TO 770

764 WRITE $\quad(3.500)$

770 DO $779 \mathrm{I}=1$, NI

I.F( $M D D(I+6,36)) 777,771,777$

771 WRंITE

$(3,558) \mathrm{N!ANE}$

COMMANDS 770 TO 771 COUNT THE LINES Tח A PAGE SO YOU DO

C. MOT IRITE OVER. THF FOLD.

772 GO TO KKK, $(774,776)$

774 . WKlTE $\quad(3,505)$

GO TO . 777

776 WRITE

$(3,500)$ 


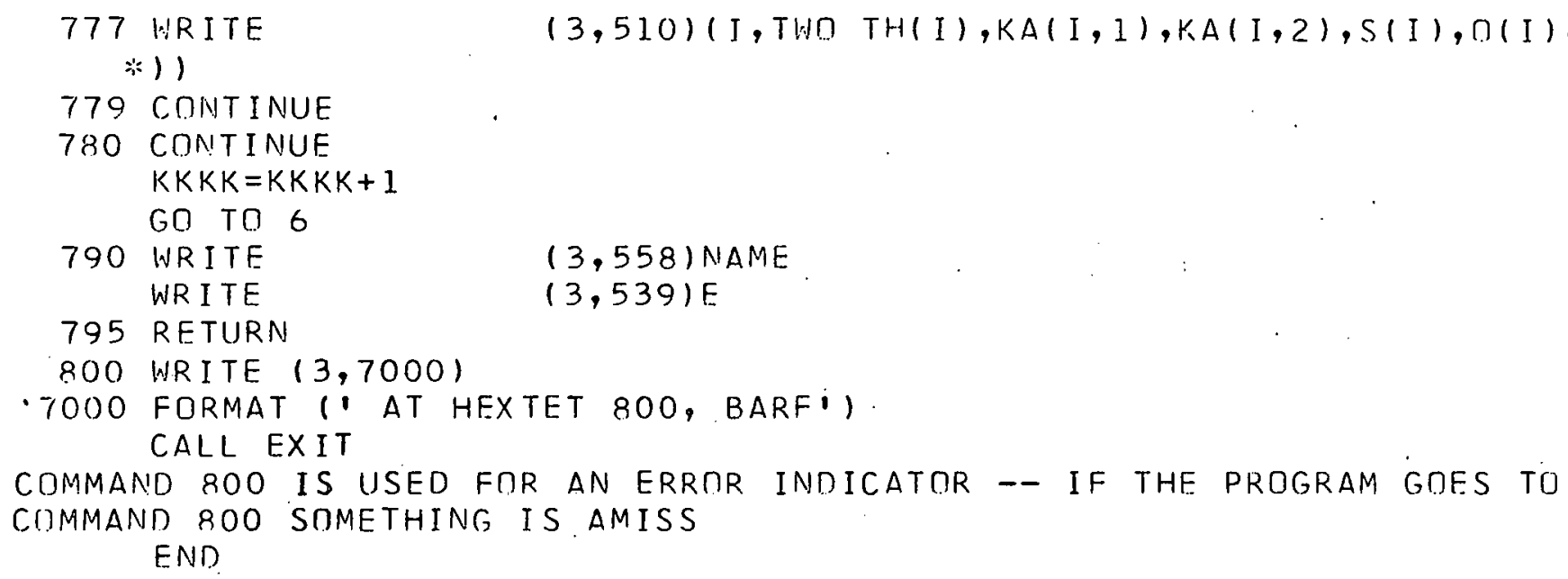


SIIRROUTINIE ORTTH

C PROGKAM TO DETERMINF CQYSTAL INDFXFS, MRTHURHMMBIC CASE.

DIMENSION TWO TH(150), S( ?50), NAHF(18), S2SO(150), SO(60), AH(1.50),

*AK(150), AL(150), FSS(150), C (150), D)F(150), KAH(150), KAK(150), KAL (150)

$\because:$

INTEGER*2 K9(12.56,9)

, STMPEA $(30)$, STMRFB(30), STOREC (30), ES $(530)$

COMMON SO, TWO TH, MAMF, SZSG, NCIIT, XLAMDA, YLAMDA, NI, FTFST, TFTBLK,

*S, FS, FORMWT, DEENSTY, K9, NOCIIRE, MOHFX, NOMO

DATA STOREA/30* . /, STORER/30*0./,STMREC/30*0.1

50 FOR INAT $(1 \times, 20 I 5)$

51 FORMAT( $1 X, 10 F 10.5)$

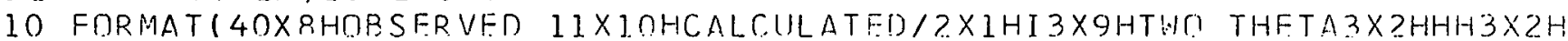
*KK $3 \times 2$ HLL $5 \times 38$ HSINE SOUARED THFTA SINE SWUAREN THETA5XIOHMIFFFREMCE $* 1 / 1$

20 FORMAT (J.H1/ IXIRA4/ 93H THE FIILLOI!IING INIFXING IS MII THF BASIS RIF * THF ORTHOIRHOM:BIC SYSTFM UITH THF FRRIR LESS THAM F8.6/

\$ 31 H THF LATTICF CONSTANT A

\#ZFRD IS F10.5, IIH AMGSTRMMS. $131 \mathrm{H}$ THE LATTICF CONSTANT BZFRO IS F

*10.5, IIH ANGSTRRMS. $131 \mathrm{H}$ THE LATTICF COWSTANT CZERO IS FIO.5, IIH MN! *GSTROIIS. )

2.5 FORMAT(57HOTHE PROGRAM FINDS MO SOLUTIIIN FOR VALUFS DF E LFSS THAM त $F 8.6 / / 11$

30 HQRMAT( IXI 3,F12.5,3I5,F17.5,F20.5,F18.5)

40. FORMAT(36HOTHE UMRESILYED WAVFLFMGTH UISED HAS F8.5,41H AND THE K-A :LPHA-ONE WAVELENGTH ISFD WAS FR. 5/16H THE DENSITY IS F6.3, $22 \mathrm{H}$ THF

* FCRMULA IVEIGHT IS F8.3,21H, AND THF MUMBER IS F6.2, IH.)

45 FORIIATIIIHOTHE FIRST I3,53H LINES ARE UNRFSOLVFN. THE REST ARE K-A * LPHA-1 L.JNES.

65 FORMAT(52H AN FSTIMATE OF THF STANIIARD DEVIATION OF THETA IS

IF10.5/65H AN ESTJMATE OF THE STAMDARD DEVIATIUN UF SINE SOUARED TH 2ETA IS F10.5/ $51 \mathrm{H}$ AN ESTIMATF IF THF STANDARM DEVINTIOM OF AZERM 3 IS FIO.5/5IH AN ESTIMATE UIF THF STANDARD DEVIATION IIF BZFRO IS FIO 4.5/bIH AN ESTIMATE OF THF STANIIARD DEVIATION DF CZFRO IS FIO.5//1

70 FORMAT ( 18 A 4)

89 FORMAT( 31 IHOERRMP. PRMBARIYY CIIBIC CRYSTAL.//)

90 FOPRAT(7F10.2)

99 FORMAT(IHI//24XI8A4//)

CALL TIMF. (ELPSTM)

WR.ITE $(3,1010)$ FLPSTM

1010 FORMATI// ENTFRJNG ORTHO. FXFCITIOM TIME', FIO.2,' SEC.')

$K K K K=0$

$I=40$

$J=41$

$K=42$

$1 .=43$

$1=44$

$N=45$

$L F=46$ 


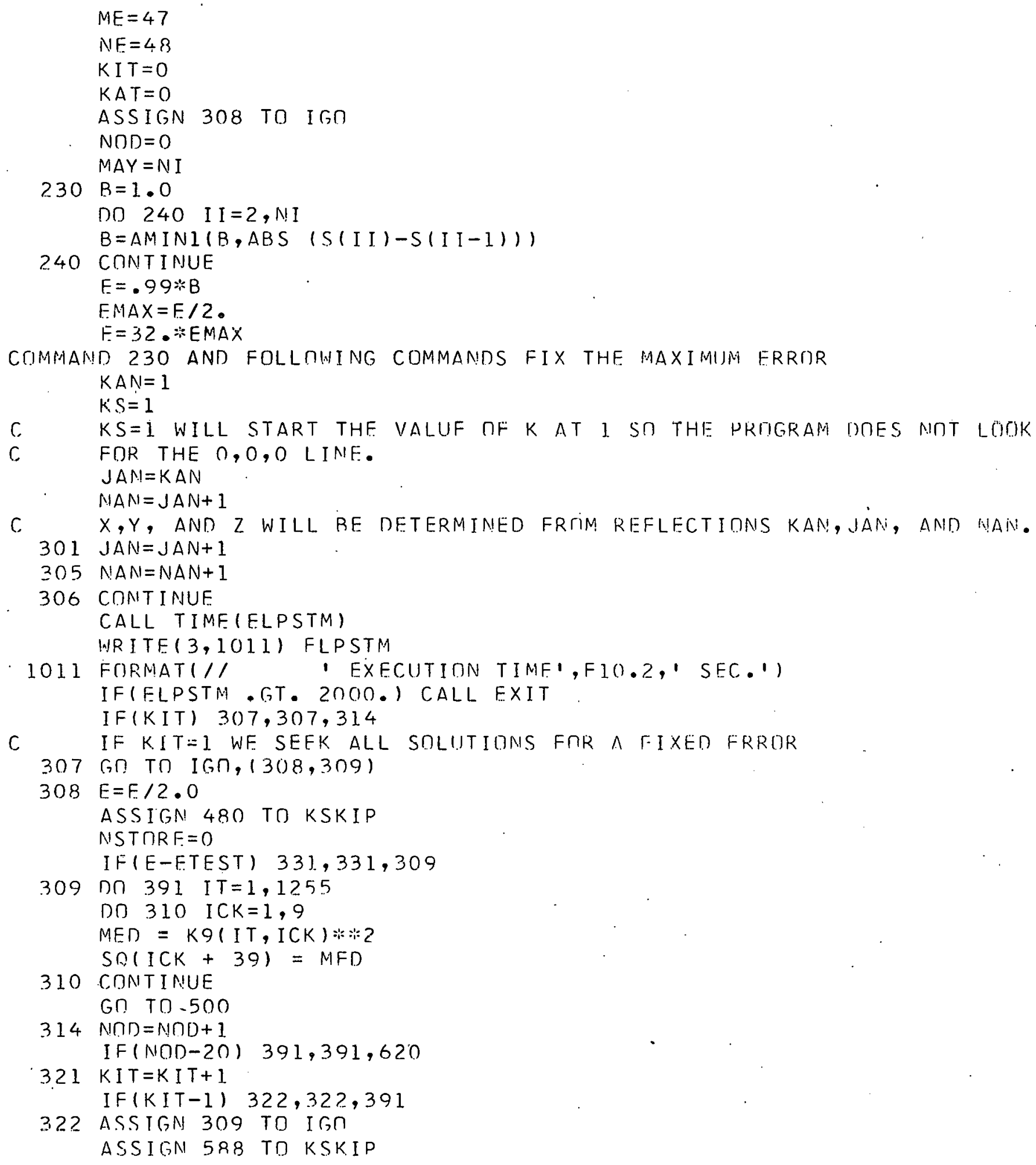


(B) $\operatorname{Tn} 309$

331 IF(KIT) $332,332,32.1$

$332 E=F * 2$.

GO TO 321

C THIS FIXES THE ERROR AND SEEKS ALL SOLUTIIINS

500. $D=S O(I) *(S O(M) * S O(N F)-S O(N) * S O(M F))-S O(J) *(S O(L) * S O(N E)-S O(N) * S Q(L$

$X F))+S O(K) *(S \cap(L) * S \cap(M E)-S \cap(M) * S \cap(L F))$

$C$ D IS THE CDEFFICIENT DETFRMINANT

IF(D) $526,501,52 \mathrm{~K}$

501 RANK $=S Q(T) * S O(L)+S \cap(J) * S \cap(M)+S \cap(K) * S \cap(N)$

IF (RANK) $391,391,502$

502 RANK $=S Q(I) * S O(L F)+S O(J) * S O(M F)+S O(K) * S O(N E)$

$\mathrm{C}$ IF(RANK) $391,391,505$

COMMANISS 501 AND 502 RFJFCT ROWS WITH ALL ENTRIES ZERO.

C.

$505 U=S(K A N) *(S O(M) * S O(N E)-S O(N) * S O(M E))-S(J A N) *(S Q(J) * S O(N F)-S O(K) * S$ $*(O)(M E))+S(N A N) *(S O(J) * S O(M)-S O(K) * S O(M))$

IF (U) $391,506,391$.

$506 V=S O(I) *(S$ (JAN) *SO(NE) -S (NAN) *SO(N)) -S (KAN) * (SO (L) *SO(NF) -SQ(N) $* * S O(L E))+S O(K) *(S$ (NAN) $* S O(L)-S(J A N) * S O(L E))$

IF (V) 391,507,391

$507 W=S O(I) *(S$ (NAN) *SO(M)-S (JAN) *SO(MF)) -SO(J)*(S (NAN)*SO(L)-S (JAN $*) * S O(L E))+S(K A N) *(S O(L) * S O(M F)-S O(N) * S O(L E))$

C. $\mathrm{IF}(W) \quad 391,510,391$

COMMANIDS 505 THROUGH 507 REJFCT INCNNSISTENT EGUATIONS.

$\mathrm{C}$

508 NAN! $=$ NAN+1

IF (NIAN-5) 309,309,509

$509 J A N=J A N+1$

$N A M !=J A N+1$

IF(NAN-5) $309,309,608$

510 IF(SO(I)) $511,518,511$

$511 A 22=S \cap\left(N_{1}\right)-S \cap(J) * S O(L) / S O(I)$

$A 32=S \cap(M F)-S O(L F) * S O(J) / S \cap(I)$

$A 23=S O(N)-S O(K) * S O(L) / S O(I)$

$A 3.3=S O(N F)-S O(K) * S O(L F) / S O(I)$

IF (A32**2+A33**2) 512,515,512

512 IF $(A 22 * * 2+A 23 * * 2) \quad 513,516,513$

$513 B=-A 23 / A 22$

$A=-(S O(K)-B * S O(J)) / S O(I)$

$514 \operatorname{IF}(A B S(A * S(1)+R * S(2)+S(3))-.001) 508,508,391$

515 IF (ABS $(S O(L E) / S O(I)-S(3) / S(1))-.001) 508,508,391$

$51 S$ IF (ABS $(S O(L) / S O(I)-S(2) / S(1))-.001) 508,508,391$

518 IF $(S \cap(J)) \quad 520,522,520$

$520 K \cap L D I=I$

$K \cap L D L=L$ 


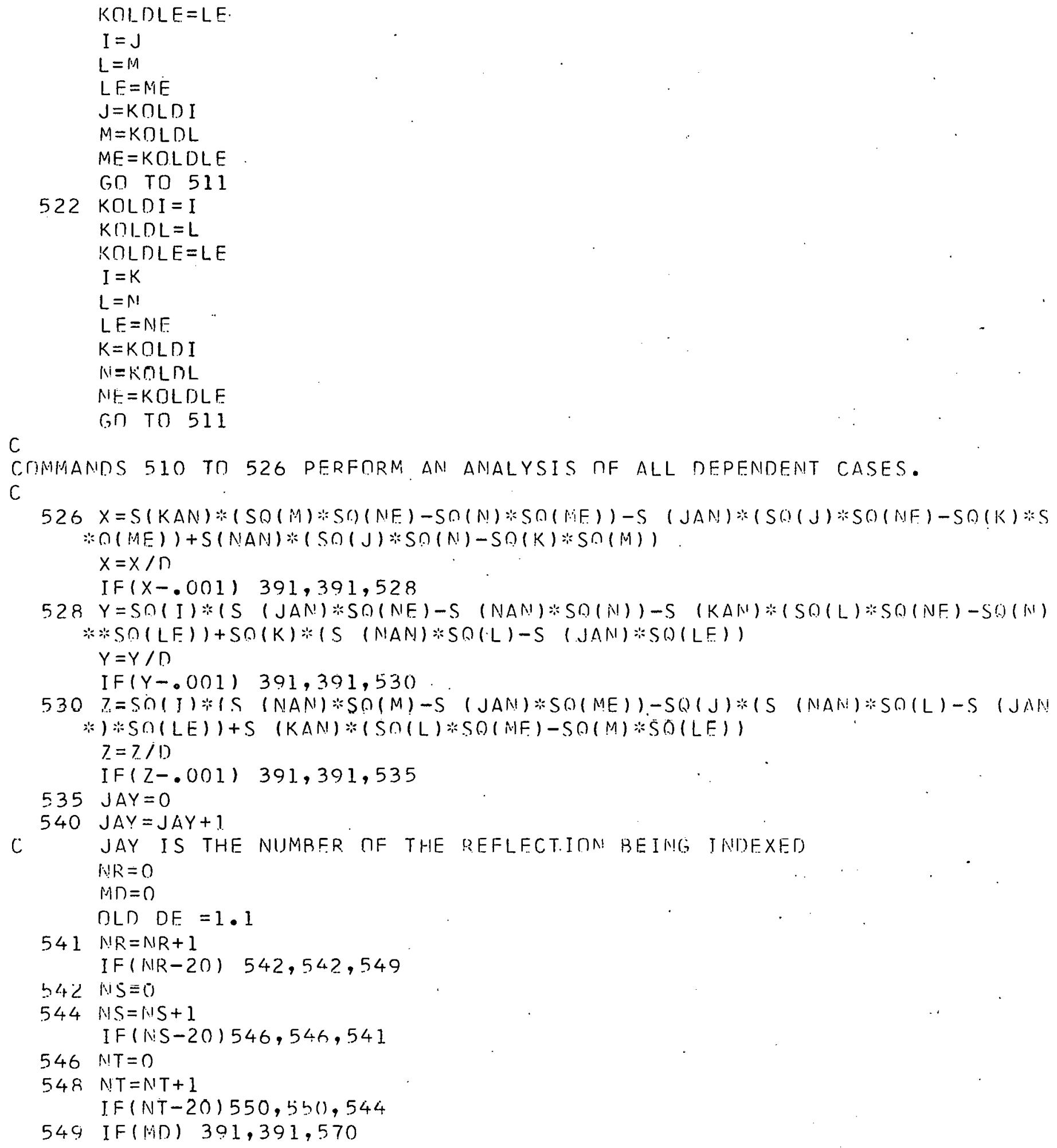


C.

C

c.

MD MON-ZEER I.IEAMS AT LEAST IMAF ACCFPTAPLF. SET MF IODICFS HAVE

BFEN FOUND FOP PEFLECTJOM JAY.

$550) \quad(.(1 A Y)=X * S O(N N)+Y: S O(N S)+7 * S O(N T)$

C(IAY) IS TIHE CAICULATFD SINF SOLIAPR THFTA

$I F(C($ JAY $)$. LF. S(JAY) + F) GO! TOI 557

$55]$ T.F(X *SOINR) + Y*SO(NS) . LT. S(JAY) + E) GR TO 544

55? IF(X * SO(NR) - LT. S(JAY) + E) Gก TO 54.1

553 I $F(n) \quad 391,391,570$

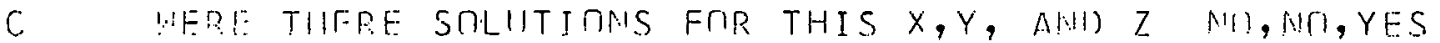

537 IF(C, (IAY) + E.LT. S(JAY)) GOT TO 548

COMAAMUI 557 ASKS IF THIS IS A SOLUTIOM NO,YES, YFS.

558 OFF=AFS (C (JAY) -S (JAY))

IF( $\cap L \cap \cap F-\cap E E) \quad 548,548,564$

C THIS COMAME ASKS IF THIS SET MF INDICFS IS BETTER THAN ALL.

C PUEYIRUS SחLUTI IMS PIn, MIT, YES.

564 IF $(. J A Y-1) \quad 566,566,567$

566 OLD DF $=$ ПFF

in $=$ ?

$B]=S O(N R)$

$B ?=\operatorname{SO}(\mathrm{NS})$

$B 3=\sin (\mathrm{N} T)$

C. THF FI ARF THE CIIRPFNT BFST SULITTION FOR THF S(JAY) RFFLFCTIMIE. GII TO 548

567 IF (AH(JAY - 1) - SO(NR)) $566,568,566$

563 IF (AK( JAY-1.)-SC(NS)) 566,569,566

$c$

569 IF(AL (JAY-1)-SO(MT)) $566,548,566$

CHMHAMUS 567,56R, ANO 569 PEJECT IJIPLICATE SFTS CIF INDICES.

C.

$570 A H(J A Y)=P .1$.

$A K(J A Y)=P 2$

$A L(J A Y)=P, 3$

$\operatorname{lit}=0$

OLO DF $=1.1$

$C(. J A Y)=X * R 1+Y * R 2+7 * R 3$

$I F(J, M Y-4) \quad 540,575,578$

391 COMTINUF

IF(KKKK) 610,6$] 0,574$

574 RFTIIRM

$575 \quad A \cap=A H(1) * S(1)+A H(2) * S(2)+A H(3) * S(3)$

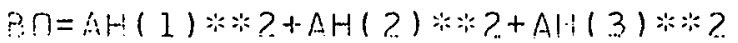

$C(?)=A+(1) * A K(1)+A H(2) * A K(?)+A H(3) * A K(3)$

$n \cap=A H(1) \div A L(1)+A H(2) * A L(2)+A H(3) \div A L(3)$

$A A=A K(1): S(1)+A K(2) \therefore S(2)+A K(3) * S(3)$

$B, B=C \cap$

$C C=A K(1) \div 2+A K(2) \div 2+A K(3) \div 2$

$1) n=A K(1) * A L(1)+\Delta K(2) * A L(2)+A K(3) * A L(3)$ 


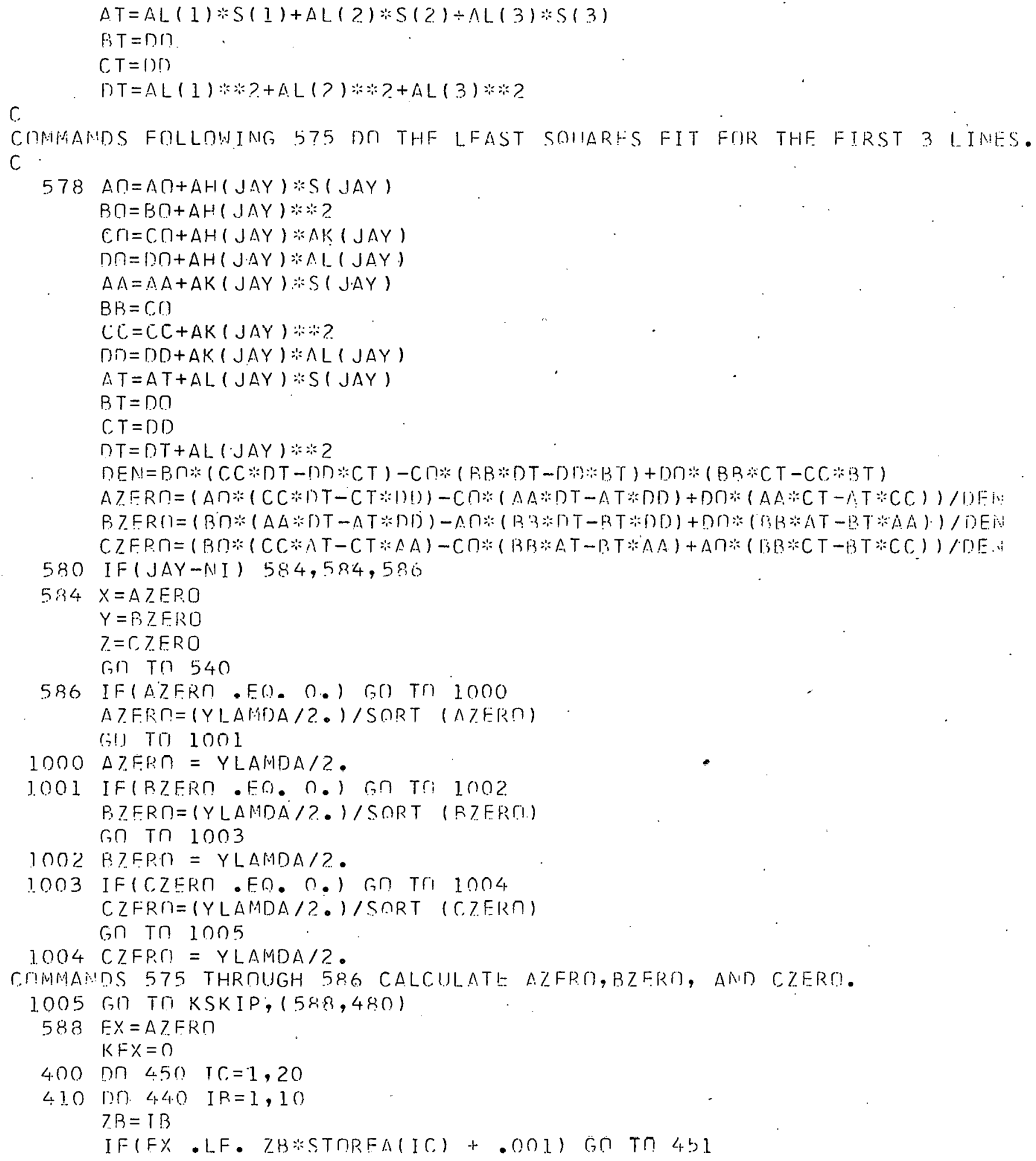




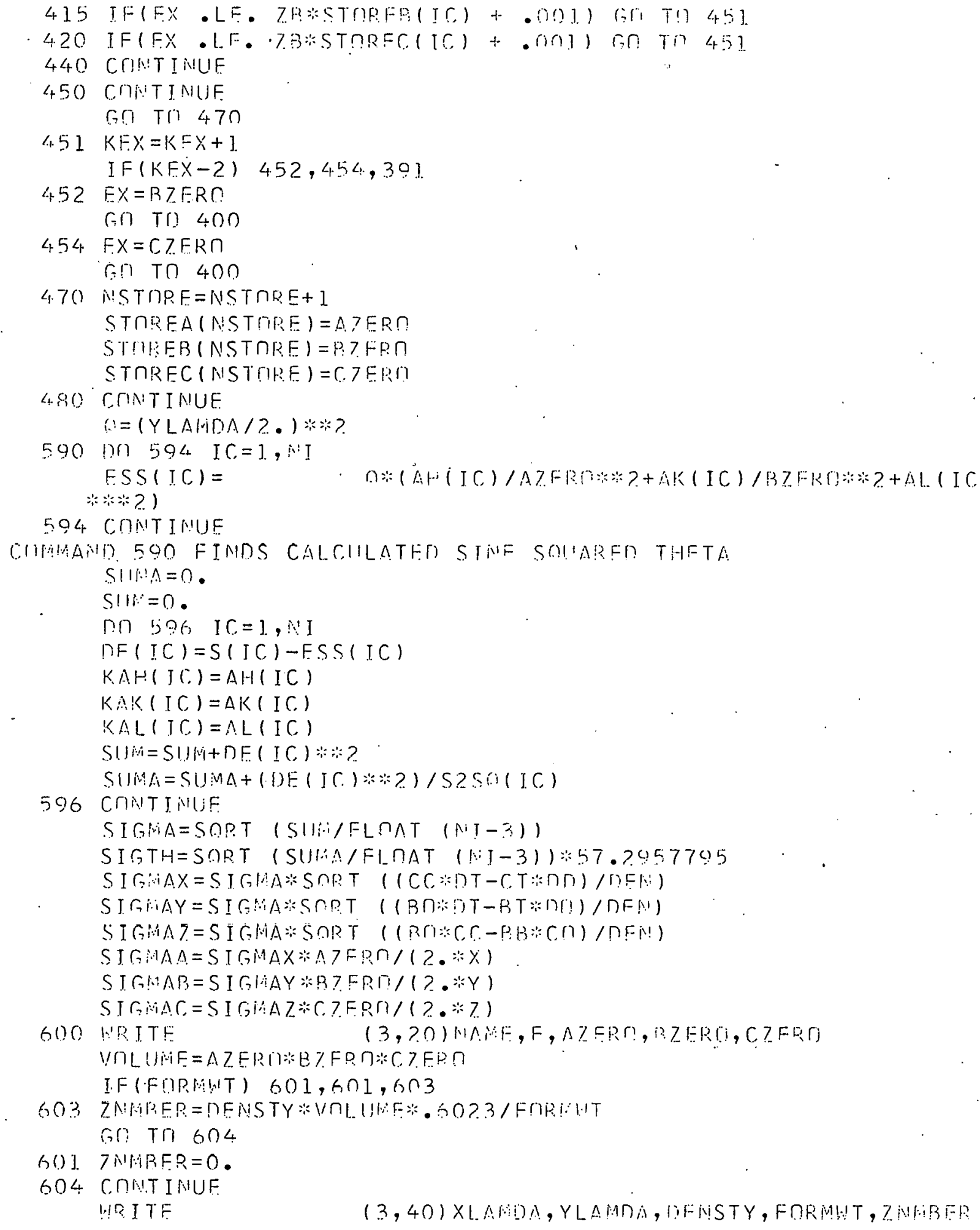




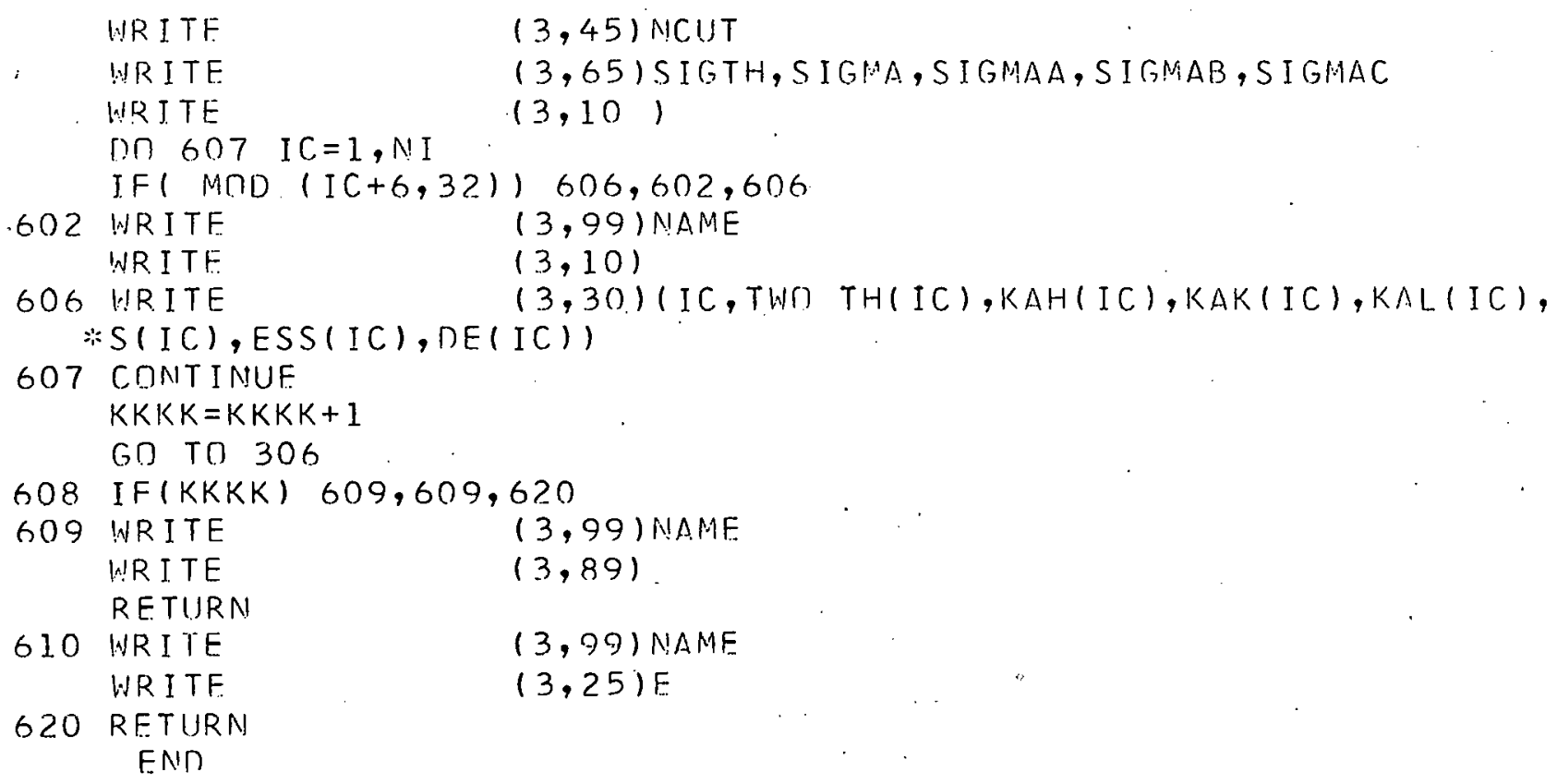

